\title{
On numeral complexity in hunter-gatherer languages
}

\author{
PATIENCE EPPS, CLAIRE BOWERN, CYNTHIA A. HANSEN, \\ JANE H. HILL, and JASON ZENTZ
}

\begin{abstract}
Numerals vary extensively across the world's languages, ranging from no precise numeral terms to practically infinite limits. Particularly of interest is the category of "small" or low-limit numeral systems; these are often associated with hunter-gatherer groups, but this connection has not yet been demonstrated by a systematic study. Here we present the results of a wide-scale survey of hunter-gatherer numerals. We compare these to agriculturalist languages in the same regions, and consider them against the broader typological backdrop of contemporary numeral systems in the world's languages. We find that correlations with subsistence pattern are relatively weak, but that numeral trends are clearly areal.
\end{abstract}

Keywords: borrowing, hunter-gatherers, linguistic area, number systems, numerals

\section{Introduction}

Numerals are intriguing as a linguistic category: they are lexical elements on the one hand, but on the other they are effectively grammatical in that they may involve a generative system to derive higher values, and they interact with grammatical systems of quantification. Numeral systems are particularly noteworthy for their considerable crosslinguistic variation, such that languages may range from having no precise numeral terms at all to having systems whose limits are practically infinite. As Andersen (2005: 26) points out, numerals are thus a "liminal" linguistic category that is subject to cultural elaboration.

Recent work has called attention to this variation among numeral systems, particularly with reference to systems having very low limits (for example, see Evans \& Levinson 2009, D. Everett 2005, Hammarström 2010). This linguistic variation has also been shown to have fascinating cognitive parallels, such that 
the development of numeral systems has been linked to the development of specific cognitive skills relating to the manipulation of precise quantities (e.g., P. Gordon 2004, Pica et al. 2004, Spaepen et al. 2011).

The processes of elaboration and change in numeral systems may be rapid, and numerals are often restructured via contact and innovation (see Comrie 2005, cf. Blažek 1999: 325). Systems may reflect these processes of elaboration over time, comparable to "the history of an old building, [seen] from the contrasting styles of its pieces, from the foundations up" (Hurford 1987: 83). These traces are more likely to be detectable in systems that have been elaborated relatively recently (see, e.g., the discussion of Nadahup numerals in Epps 2006).

It is highly likely that the variable development of numeral systems in the world's languages has been shaped in part by cultural factors - although we note that the robustness of universals in numeral composition (see, e.g., Greenberg 1978, Hurford 1987, 2007) provides evidence that cognitive processes also play a role. However, defining the relevant cultural factors is still largely a matter of conjecture. In a few cases, specific cultural practices have been convincingly linked to particular numeral strategies; for example, conventionalized yam-counting practices in Southern New Guinea have almost certainly fostered the development of a senary (base-six) numeral system in a number of these languages (Evans 2009, Hammarström 2009, Plank 2009).

More generally, the elaboration of overall complexity in numeral systems i.e., the development from highly restricted to generative systems that can name precise quantities into the tens, hundreds, or thousands - is motivated (at least in part) by social and cultural practices that encourage counting and/or keeping track of precise quantities. Many authors have suggested that these practices correspond to aspects of social complexity, such as the scale and scope of regional exchange (Winter 1999) and/or division of labor (Greenberg 1978: 291). However, the most frequently proposed correlate to numeral complexity is subsistence pattern - that is, whether a group relies primarily on hunting, gathering, and/or fishing, as opposed to farming and/or pastoralism, for primary food sources (Stampe 1976: 596, Heine 1997: 24, Winter 1999: 43, Hammarström 2008). In particular, small numeral systems have been widely associated with hunter-gatherers, who are presumed to have less need for numerals; in fact, hunter-gatherer numeral systems are typified as small and simple, as by Dixon (1980: 107-108) when discussing Australia. This generalization is no doubt linked to the widespread assumption that hunter-gatherers share a predictable package of social traits - of which some or all may be implicated in numerosity - including egalitarian social structure, low population size/density, high mobility, a relatively simple technological toolkit, a direct-exchange economy, etc. However, hunter-gatherer societies in fact exhibit considerable diversity along these parameters, which are all best understood as gradient (see Panter-Brick 
et al. 2001, Kelly 1995, Bowern 2010: 666). Accordingly, any assumption that the numeral systems of hunter-gatherers are uniformly small and simple, or even broadly similar, calls for fine-grained investigation.

If hunter-gatherer languages share characteristics that set them apart from languages spoken by agriculturally oriented and/or urban populations, then this fact has important implications for our understanding of numerosity in human language (cf. Comrie 1999). Because the period in which humans have been practicing agriculture and pastoralism represents only a small fraction of human history, the vast majority of languages spoken over time have been huntergatherer languages. Although we cannot assume that contemporary huntergatherers are directly comparable to those that lived in prehistoric times, they are obviously the closest representatives available; yet hunter-gatherer languages have been only minimally represented in typological studies of numeral systems. In some cases groups of hunter-gatherers have been intentionally excluded due to assumptions that many of them have no true numerals at all (e.g., Hanke 2005, who does not include Australian languages for this reason); in other cases, their languages are little represented simply because they constitute a small fraction of the contemporary languages of the world (and moreover are often poorly documented), so necessarily make up only a small part of even a broad sample (e.g., Comrie 2011, Greenberg 1978).

In this article, we investigate the characteristics of hunter-gatherer numeral systems, and consider these against the broader typological backdrop of contemporary numeral systems in the world's languages. Our survey focuses on the numeral systems of 193 languages spoken by peoples with a strong huntinggathering orientation, located on four continents: North America (primarily California and the Great Basin), South America, Australia, and Africa. These are areas in which many hunter-gatherer groups are present, and where it is possible to systematically investigate variation in numeral system complexity across and within these and other groups. For comparative purposes, we also include seven hunter-gatherer languages spoken in Asia. Finally, we compare the trends observed among these languages to those exhibited by the languages of their agriculturalist, semi-agriculturalist, and/or pastoralist neighbors (with the exception of Australia, which has no native agriculture), drawing from our survey of 204 of these non-hunter-gatherer languages and from the results of other typological surveys of numerals (Greenberg 1978, Hanke 2005, Hammarström 2010, Comrie 2011).

We focus on the following questions in our investigation:

(i) How does numeral complexity pattern across and within the huntergatherer languages in the regions investigated (principally the four focal areas)? Specifically, we consider the upper limits of native systems, limits to sequences of underived native ("atomic") numeral lexical items, and the values and multiplicity of bases. 
(ii) Do we find evidence that numeral complexity correlates with subsistence pattern and/or other sociocultural parameters? To what extent can we generalize across hunter-gatherer numeral systems? Where systems are small, are they relatively uniform? How much diversity do they allow in the possibilities for numeral formation?

(iii) What processes can be identified that indicate the elaboration and development of numeral systems over time, and are these more or less evident in hunter-gatherer languages?

As the following discussion will elaborate, we find that languages spoken by hunting-gathering peoples exhibit considerable variation in their numeral systems, and that subsistence practice is not in itself a predictor of numeral system type. However, there does appear to be at least some hint of a correlation between numeral complexity and subsistence pattern, but this is regionally dependent. The clearest correlations relating to numeral system trends are areal.

\section{Methodological considerations}

Our survey focuses on the hunter-gatherer languages spoken within the four designated focal regions (Australia, North America, South America, and Africa). We have included as many of these languages as possible within the constraints of the available data (many are not well described). The total number of hunter-gatherer languages sampled (193) represents approximately onethird of the total number of hunter-gatherer languages spoken in the world today, which is itself only a small fraction of the number of languages spoken by hunter-gatherers throughout human prehistory (Lee \& Daly (eds.) 1999).

Across the four regions, the languages are distributed as follows. For Australia, we sampled 122 languages (including several closely related varieties) from 7 families, concentrated in the northwest of the country but extending into the south and east where data were available. All groups are huntergatherers; Australia has no native agriculture. For California and the Great Basin in North America, our sample includes 35 languages from huntinggathering groups, corresponding to 10 language families. The South American sample consists of 19 hunting-gathering-focused language groups from 9 families, with a concentration in the northwest Amazon but extending throughout the continent where data were available (note that very few South American groups are "pure" hunter-gatherers; see below). The African set is composed of 17 hunter-gatherer languages from 7 families. In addition, as noted above, we include seven other languages spoken by hunter-gatherers in Northeast and Southeast Asia, viz. Jahai (Aslian), Semelai (Aslian), Agta (Austronesian), Ainu (isolate), Ket (Yeniseian), Kolyma Yukaghir (Yukaghir), and Nivkh (isolate). 
In order to contextualize the hunter-gatherer languages surveyed within their regional contexts, we included the following non-hunter-gatherer languages in our survey. From California, the Great Basin, and the U.S. Southwest, we sampled an additional 17 languages spoken by agriculturalists and 5 languages spoken by peoples practicing a more mixed subsistence (e.g., agriculture and hunting-gathering in different parts of the year), corresponding to 5 language families (of which 2 are also represented by hunter-gatherers in our sample). From South America - where the majority of groups practice some agriculture - we included 105 languages from groups we classified as primarily agricultural, and 62 languages from groups practicing more mixed subsistence (e.g., seasonal Je peoples); these languages contributed an additional 29 language families to our sample, plus several more shared with the hunter-gatherers. Finally, we included 13 agriculturalist/pastoralist and 2 mixed-subsistence languages from Africa, representing 4 families (of which 3 are also represented among the hunter-gatherers), ${ }^{1}$ spoken in the same general regions as the huntergatherer languages surveyed.

Because our focus is on hunter-gatherer languages, which are relatively few in today's world, this survey does not contain a balanced sample. We have not controlled systematically for language family, since this would drastically reduce our sample size, and since both numeral systems and subsistence strategies can change fairly rapidly. Although this approach limits the power of our generalizations, it allows us to bring to wider attention a group of languages that has been largely ignored in other typological studies. Because of the small and unbalanced sample numbers, we have focused on qualitative generalizations and tendencies that arise from the data, rather than conduct an extensive statistical survey.

Our primary focus is on languages spoken by peoples with a huntinggathering orientation, but subsistence practices are in many cases complex, and frequently do not lend themselves to clear-cut categorization. Moreover, subsistence patterns vary considerably across and to some extent within case study regions. In Australia, indigenous groups are exclusively hunter-gatherers. In South America, on the other hand, the distinction between hunter-gatherer and agriculturalist is far from clear-cut, with most groups engaging in both foraging and farming to varying degrees, while those with a clear foraging emphasis are relatively few (and may still engage in close management of non-domesticated

1. Four of these African agriculturalist languages are in fact also spoken by hunter-gatherer Pygmy groups. The degree of dialectal separation between these groups and their agriculturalist neighbors varies (Bahuchet forthcoming), but our sources describe these languages as spoken by the agriculturalists without giving information on how they are spoken by huntergatherers. Because we only have data from the agriculturalist varieties of these languages, we have included them here with the agriculturalist sample. 
resources; see, e.g., Balée 1992, Posey 1984, Politis 2007, Rival 2006: S8283, Zent \& Zent 2004). Moreover, detailed information about past subsistence practices is lacking for many of these groups, and for some (e.g., Yanomami, see Early \& Peters 2000) reliance on agriculture has increased together with proximity to the national society and availability of metal tools; for others, a hunting-gathering focus may have emerged as a survival strategy following European contact (as, for example, Balée 1999 argues for the Tupí-Guaraní Guajá). In North America and Africa, similarly, various groups have altered their relative dependence on foraging or farming over time. Other parameters also vary among hunting-gathering peoples, such as their dependence on aquatic resources (e.g., the Seri people of northern Mexico, who extract most of their protein from the sea), which may be linked in turn to social patterns like mobility. Mobility patterns very widely; for instance, in North America mobility was high in Great Basin groups, while some populations in southern California, such as speakers of Chumashan languages, were largely sedentary. Similarly, in Africa, the Aka, Baka, and Mbuti groups are semi-nomadic, while many other Pygmy groups live in settled villages (Bahuchet forthcoming).

Accordingly, we characterize subsistence orientation here with reference to a set of criteria. These include the actual proportion of wild/domesticated food consumed, the amount of time spent on foraging/farming related activities, and the cultural importance of these activities, relative to other groups in the wider region. ${ }^{2}$ More traditional subsistence practices are prioritized where there is evidence for substantial recent change.

A further consideration within our sample of hunter-gatherer languages is language shift. In some parts of the world, imbalanced social relations between hunter-gatherers and their neighbors have caused the hunter-gatherers to abandon their original languages and adopt those of their neighbors (see, e.g., Spielmann \& Eder 1994: 307). In some cases, these shifts are quite old, such that the hunter-gatherers now speak their own variety of the more widespread language. Shifts of this kind are known to have occurred in Southeast Asia, where the Agta peoples have adopted Austronesian languages (Blust 1976, Reid 1987), and the Aslian groups apparently switched to Mon-Khmer at some point in the relatively distant past (Junker 2002: 151). These shifts have also been argued to have occurred in Africa; for example, the Bantu and Ubangian languages spoken by the Aka and Baka Pygmies are apparently the result of past shifts (Bahuchet 1993, forthcoming), though see Blench (1999) for an alternative view. Many of these languages are now unintelligible with those of the agriculturalists, and there is considerable variation among their numeral systems. In the remainder of our sample, no shifts to agriculturalist languages are doc-

\footnotetext{
2. For most of these groups, only approximate estimates are available.
} 
umented for the Australian, North American, or South American case study regions (where it is more common to find groups that maintain their languages and shift their subsistence practices, in some cases from agriculture to foraging). ${ }^{3}$

In surveying numeral systems, we follow the working definition of numerals as given in Hammarström (2010: 10): "spoken, normed expressions that are used to denote the exact number of objects for an open class of objects in an open class of situations with the whole speech community in question." 4 Accordingly, we do not include auxiliary or secondary counting systems, which are restricted to particular entities or social situations, although we note that these represent an intriguing additional facet of numeral complexity (and may in some cases represent initial stages in the development of new complexity in numeral systems as defined here). For example, some Australian languages have birth-order names, and other languages have counting terms used only for entities like cattle, e.g., Gurindji (Pama-Nyungan), or coconuts (Wuvulu, an Austronesian language of New Guinea; Hafford 1999: 37-39, cited in Hammarström 2010: 12). A few South American languages - e.g., Dâw (Nadahup; Martins 2004) - have tally systems (often finger-based) involving imprecise quantitative terms, such as 'even' and 'odd'. We also do not consider discoursebased variation in numeral manipulation (see Reed \& Lave 1979). On the other hand, we do take this definition to include terms that are semi-conventionalized but not completely fixed, as long as they correspond to precise values (both because this meets our criteria for numerals and because such variation is likely to be overlooked in grammars and dictionaries); examples include the terms for 6 to 10 in the South American languages Hup (Nadahup) and Iquito (Zaparoan); e.g., $6=$ 'one finger stands up', 'add another finger', etc. ${ }^{5}$

3. In California, language shift toward Yokuts was apparently under way in some communities of speakers of Western Mono and Tübatulabal (cut short by a more general shift to English), but all of the groups concerned are hunter-gatherers. In South America, there are ethnohistorical accounts of hunter-gatherer groups merging with agriculturalist neighbors (e.g., Nadahup bands being absorbed into Arawak or Tukanoan groups as low-ranked clans), but these do not involve entire speech communities and are as yet unverified.

4. For this reason, we include only one of the two numeral systems that occur in Seri, a huntergatherer language of northern Mexico. As Moser \& Marlett (2005: 2) report, "since the last century, it is reported that in Seri there are two numeral systems in series, including one that is used only for counting. Currently, this series is known, although it is not used frequently and is only used when one is counting" (our translation from Spanish). It is possible that this auxiliary counting system, which is much more restricted, represents an older numeral system that has been partially superseded by the more complex one. We include only the more complex system in our figures, but note the properties of the simpler system in footnotes.

5. As an anonymous reviewer points out, subitizing (i.e., the rapid reckoning of the quantity of items within a space; see Kaufman et al. 1949, Gross 2011) may be a relevant aspect of numerosity as it occurs in some of the language groups considered in this article. Since subitizing limits are usually around 4 or 5 , subitizing may be a more relevant cognitive process 
This survey focuses on cardinal numerals, and considers their limits, bases used, and historical sources (etymological or loan). Data were obtained from a wide range of published and unpublished sources. ${ }^{6}$ These are of varying quality and thoroughness, so figures used in this study represent attested/known numeral values only. Languages were excluded where significant gaps in the recording were judged to exist, such that an accurate assessment of the system's complexity could not be made. A list of languages and sources used is given in the Appendix.

\section{Extent and complexity of numeral systems}

\subsection{Languages with vague or ambiguous numeral terms}

A number of the world's languages have been described as having no "basic" numeral terms at all; that is, terms whose primary meaning corresponds to a precise numeral quantity. Such anumerical systems are very rare, as discussed by Hammarström (2010: 20). An oft-cited example is Pirahã (Mura family, South America; D. Everett 2005: 623):

(1)

$$
\begin{array}{ll}
\text { Pirahã } & \\
\text { hói } & \text { 'small size/amount' (or 'one') } \\
\text { hoí } & \text { 'larger size/amount' (or 'two') } \\
\text { bá a gi so } & \text { 'cause to come together, many' }
\end{array}
$$

Other languages are reported to have basic terms for 'one' and/or 'two', but allow vague or imprecise readings of terms beyond these ('some', 'many', 'a few'). Both exact and approximate uses exist for some terms; i.e., they may be interpreted as either having a precise value or a vague reference (compare English a couple, which can mean 'exactly two' or 'a few', but not 'exactly four'). This fact often leads to dissent about whether such terms are true numerals see, for example, the discussions concerning Pirahã (D. Everett 2005, Frank et al. 2008, Nevins et al. 2009: 387), Jarawara (Dixon 2004b: 179-180, C. Everett forthcoming), and Warlpiri (Hale 1975, Bowern \& Zentz 2011). It can be very difficult to establish which meaning is "primary", even in an experimental context; when drawing from written sources, determining whether the exact or approximate meaning is primary - or sometimes whether an approximate meaning even exists - is usually impossible. Accordingly, for all languages in

\footnotetext{
to small numeral systems than enumeration or counting. Harris (1987) provides anecdotal information about subitizing strategies among Australian Aboriginal groups, but provides no source for the information. We lack sufficient data to discuss this area in further detail.

6. Most of these are primary sources (dictionaries, grammars, and word lists; see Appendix and References). Our information for several languages comes from Chan (1998-2011; used with permission); we gratefully acknowledge this useful source of comparative numeral data.
} 
our sample having numeral terms documented as both exact and approximate, we included these as "true" numerals for the purposes of this study.

Vague or ambiguous uses of numeral terms appear to be particularly common in Australia, where they are documented for $24 \%$ (29 languages) of the languages sampled. Several examples also appear in South America (10 of the 190 total languages sampled) ${ }^{7}$ however, only five of these (Pirahã and the four members of the Yanomami family) are classified here as hunter-gatherer focused, while the rest are relatively agricultural. No vague/ambiguous numeral uses were identified in the North American, African, ${ }^{8}$ or Asian languages surveyed. Vagueness or ambiguity of numeral terms does not appear to be closely associated with hunter-gatherer subsistence, since this property is neither typical of nor unique to hunter-gatherer languages. Vagueness/ambiguity does appear to be associated with restricted numeral systems (see also Hammarström 2010: 17) - most of the languages in our sample having vague/ambiguous terms are limited to five or fewer numeral terms - but it is not a general property of such systems, which in most cases do not appear to allow vague interpretations of numeral terms (see Bowern \& Zentz 2011 for additional discussion concerning Australian systems).

\subsection{Limits of systems}

A clear measure of numeral complexity is the upper limit of the system. We define the upper limit according to the highest attested native (i.e., non-loan) numeral term in a sequence. ${ }^{9}$ This definition excludes higher terms in systems that do not end discretely; for example, some Australian systems have additional terms for certain higher numerals out of sequence (usually reserved for particular entities, such as playing cards), and in some South American systems, such as Hup (Nadahup), terms for 11 to 14 may also be used for 16 to 19 and are thus understood as tally terms rather than true numerals (i.e., they mark elements in a sequence, but do not refer to a precise quantity; see Section 2 above). In most languages where loan numerals exist, these pick up where the

7. These are Tenharim (Tupí-Guaraní), Hixkaryana (Carib), Kulina (Arawá), Kwaza (isolate), Esse Ejja (Tacanan), and the four members of the Yanomami family. We also include Pirahã (Mura) here, in keeping with our criteria above, although we recognize that D. Everett (2005 inter alia) and Frank et al. (2008) provide cogent arguments to show that the Pirahã quantifying terms are not true numerals.

8. With the exception of the Kxoe term $x / o$ a, which functions both as a verb 'to be little, few, some' and as an alternative way (among other terms) of expressing the quantity 'three'.

9. That is, our working definition of limits excludes material that is obviously not native to the language in question. For example, several Pano languages (South America) have borrowed Quechuan numeral terms for values above 5 (apparently reflecting elaboration of the native system via language contact); in such cases, the numeral limit is here assessed as 5 . Borrowing of numeral terms within the sample is addressed in Section 4.3. 
native terms leave off, and are therefore excluded; however, in the few cases where there are loans that intervene in a sequence of native terms, the upper limit is taken to be the highest native term in a sequence with no more than two intervening non-native numerals. ${ }^{10}$ This definition of numeral limits includes conventionalized terms that are internally analyzable (i.e., have transparent etymological sources); the limits of opaque lexical "atoms" are considered below.

Detailed information on numeral limits is frequently unavailable. For many languages - primarily for systems going above 10 - information on ACTUAL limits was not accessible, so the highest ATTESTED numeral term was taken instead to represent an upper value in the system. Because of the imprecise nature of these data, our discussion of the limits of systems prioritizes three broad categories: 5 or under; between 6 and 19; and 20 or over (note that documentation of numerals above 20 is particularly patchy). A further advantage of these categories is that they are likely to correspond roughly to the incremental steps a developing system will take (i.e., languages tend to develop bases that generate sets of higher numerals, as opposed to simply adding numerals to a sequence one at a time). Those languages where reliable data were unavailable even for values under 20 were excluded from the sample.

We also focus on documented limits to systems, as opposed to reconstructed changes to numeral systems over time. There is evidence in some cases that native systems originally did attain higher limits, but have been replaced by borrowed numerals from European or other languages. For example, the Aslian languages Jahai (Burenhult 2005) and Semelai (Kruspe 2004), of Southeast Asia, have borrowed almost all of their numerals from Malay, and have lost most of the earlier Mon-Khmer numeral forms that are still attested in related languages. Conversely, it is well known that languages may augment their limits through borrowing and/or innovation, as has been argued for Hup and Yuhup (Nadahup, South America; see Epps 2006). It is often difficult to distinguish between elaboration and replacement via borrowing.

Examples of languages with relatively low upper limits include Bardi (2), which has basic numeral terms for 1 to 3 , with 4 a reduplication of 2 (Bowern forthcoming). Some speakers give ni-marla 'hand' as a way to refer to 5 , but not all speakers accept this. ${ }^{11}$ Another example of a language with a small

10. There are no attested cases of a sequence of more than two loan numerals followed by an extended sequence of native terms.

11. Speaker variation is sometimes documented in the Australian numeral systems, but not systematically so. For Bardi, speakers differ greatly in the extent to which they accept numerals beyond those given in (2). Materials from the 1920s include forms such as gooyarra agal gooyarra agal gooyarra agal gooyarra 'two and two and two and two' (for 8), but current speakers uniformly described such phrases as ad hoc enumerations which sounded contrived and ungrammatical. However, the presence of such formations in earlier materials - which date from a time when Bardi was still used in daily conversation - may suggest that the system has contracted as speakers' knowledge of English has increased. 
system is Dâw (3), which has basic numeral terms for 1 to 3 only; above this (up to 10) generic terms indicating 'even' or 'odd' may be used, typically together with finger gestures (Martins 2004: 391).

\begin{tabular}{|c|c|}
\hline Bardi (Nyulnyulan, & stralia) \\
\hline arinyji & ' 1 ' \\
\hline gooyarra & '2’ \\
\hline irrjar & 3 ' \\
\hline gooyarra-gooyarra & '4' \\
\hline
\end{tabular}

(3) Dâw (Nadahup, South America)

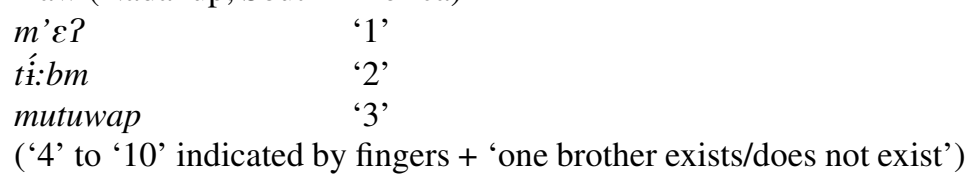

We find striking variation in numeral limits among the hunter-gatherer languages sampled, most notably across the case study areas (see Figure 1).

The Australian languages surveyed tend generally toward low limits. None of these languages have numeral terms above 20; accordingly, they may all be classified as "restricted" (Comrie 2011; see Zentz \& Bowern 2011). Most of the languages $(80 \%, n=97)$ have an upper limit of 3 or 4 , but several languages have contiguous systems that extend up to $2(4 \%, n=5), 5(8 \%$, $n=10), 6(4 \%, n=5)$, or $10(3 \%, n=4)$; one language, viz. Gamilaraay (Pama-Nyungan), goes to 20 .

Conversely, languages in the California/Great Basin region tend toward relatively high limits. All of the hunter-gatherer languages sampled (for which adequate data are attested) have upper limits of over $10(n=32) .{ }^{12}$ Most $(88 \%$, $n=28)$ have attested terms up to 30 or above, while the remaining $12 \%(n=4)$ have attested limits of between 12 and 25 . About half $(47 \%, n=15)$ have documented terms for 100 or above and $12 \%(n=4)$ have attested native terms for 1000 or above.

Numeral limits for South American hunter-gatherers are generally low. Of the languages for which reasonably reliable data on limits are available $(n=18), 61 \%(n=11)$ have an upper limit of 5 or below (of these, the four Yanomami languages are limited to 2, three other languages have limits of 3, one goes up to 4 , and two to 5). Six languages (33\%) have limits of 10 , and only one (the isolate Huaorani; $6 \%$ of total) is documented as having numerals beyond 20 .

12. The alternative counting system in Seri (not included in these figures; see Section 2 above) is lower, with an upper limit of 10 ; the more complex system has numerals attested up to 1000 . 
Limits in the African hunter-gatherer languages are more variable, but also tend to be relatively low. $41 \%(n=7)$ have an upper limit of 5 or below (these include some Bantu and Cushitic varieties), $24 \%(n=4)$ languages have attested limits of 10 , and $35 \%$ ( $n=6$, all Bantu or Cushitic) have attested limits between 100 and 1000 . We note that Bantu and Cushitic varieties - which presumably represent cases of past language shift - are represented in all of these categories; on the other hand, the southern African hunter-gatherer languages (Khoe, Tuu, and Kx'a families) have uniformly low upper limits of 10 or below.

In Asia, the high numeral systems of the northeastern hunter-gatherer languages all appear to be of native origin, and exhibit attested values well beyond 100. The Aslian and Agta languages of Southeast Asia use numeral systems that derive from non-hunter-gatherer languages (Agta through language shift and Aslian primarily through borrowing); they appear to have maintained the complexity of these systems since adopting them.

A comparison of these results with the patterns exhibited by non-huntergatherer languages reveals that the clearest numeral trends in the regions investigated are areal, rather than directly subsistence-related (compare Comrie 2011, who shows restricted systems to be clustered predominantly in Australia and South America). Australia is characterized by both low numeral limits and hunting-gathering subsistence, but because agriculture is entirely absent it is impossible to distinguish between areal and subsistence-related patterns. The California/Great Basin sample reveals little difference between the huntergatherers and the more agriculturally focused groups; of the latter, close to two-thirds of the twenty languages included in our survey have attested limits of 100 or above, several go above 1000, and only one is below 20. These results are consistent with those of Hanke (2005) and Comrie (2011) for North American languages more generally. The Asian hunter-gatherer languages examined also conform to broader areal trends (Comrie 2011, Hammarström 2008).

There are some indications that subsistence pattern may be relevant to numeral limits within certain regions. In South America, as shown in Figure 2, the hunter-gatherer systems surveyed are twice as likely as the agriculturalist and mixed-subsistence systems to be limited to 5 or below, whereas the more agriculturally oriented languages are far more likely to extend beyond 20 (of these, at least $8 \%$ go to 100 or above, ${ }^{13}$ and a few languages - primarily Quechuan - have documented terms into the thousands). In general, then, it appears that systems of very low limits are widely attested across subsistence foci in South America, but only agriculturally oriented peoples (with the exception of the Huaorani) have elaborated their systems beyond 20. However, the fact that many agriculturalist groups have not done so suggests that

\footnotetext{
13. As noted above, more languages may in fact go higher than 100, but lack documentation.
} 


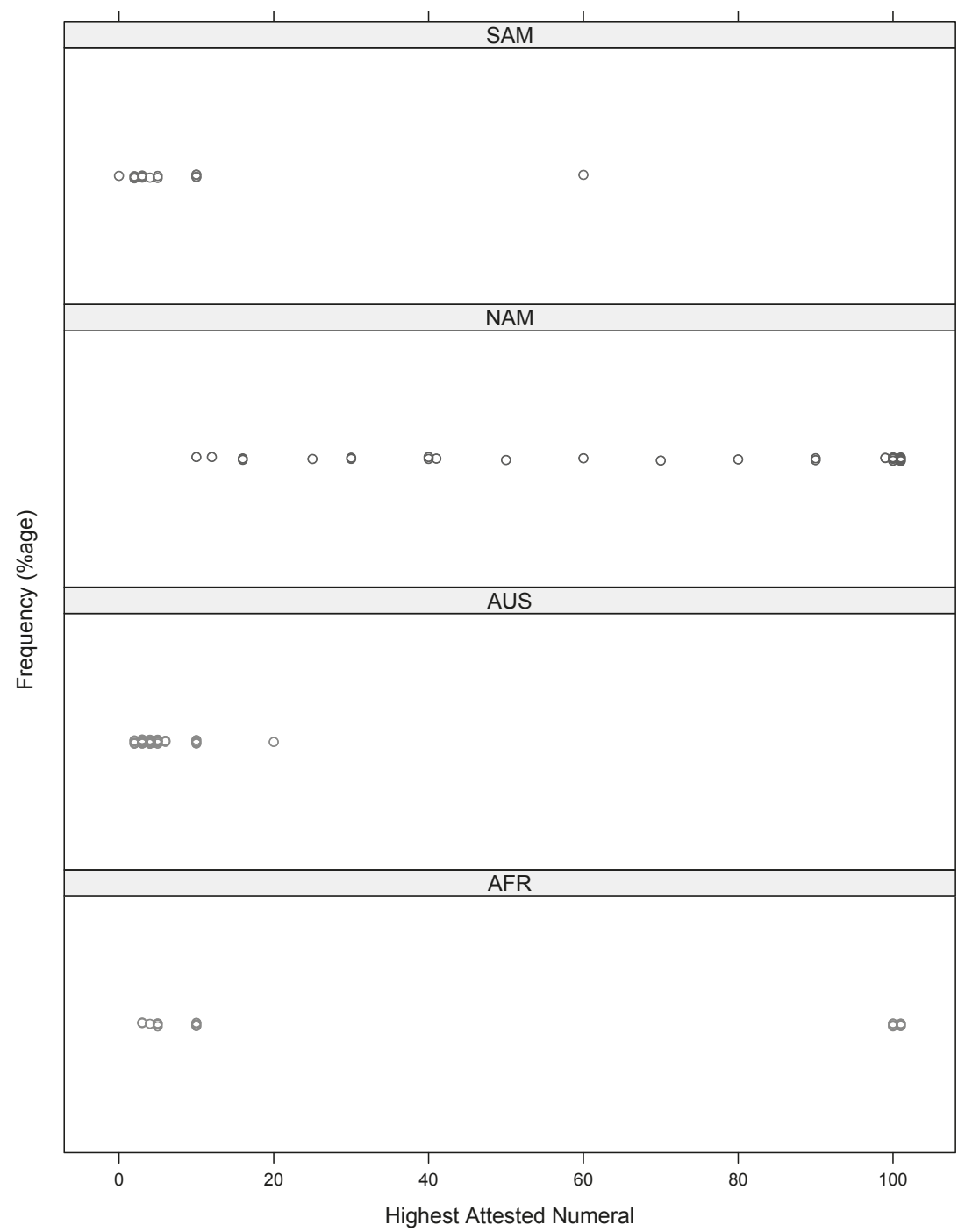

Figure 1. Distribution of highest attested numerals across hunter-gatherer languages $($ SAM $=$ South America,$N A M=$ North America,$A U S=$ Australia,$A F R=$ Africa $)$

subsistence-related practices are not themselves a sufficient requirement for elaboration.

Similarly, while a high proportion of the African hunter-gatherer languages have low limits (10 or below), all of the fifteen agricultural/pastoral/mixed- 


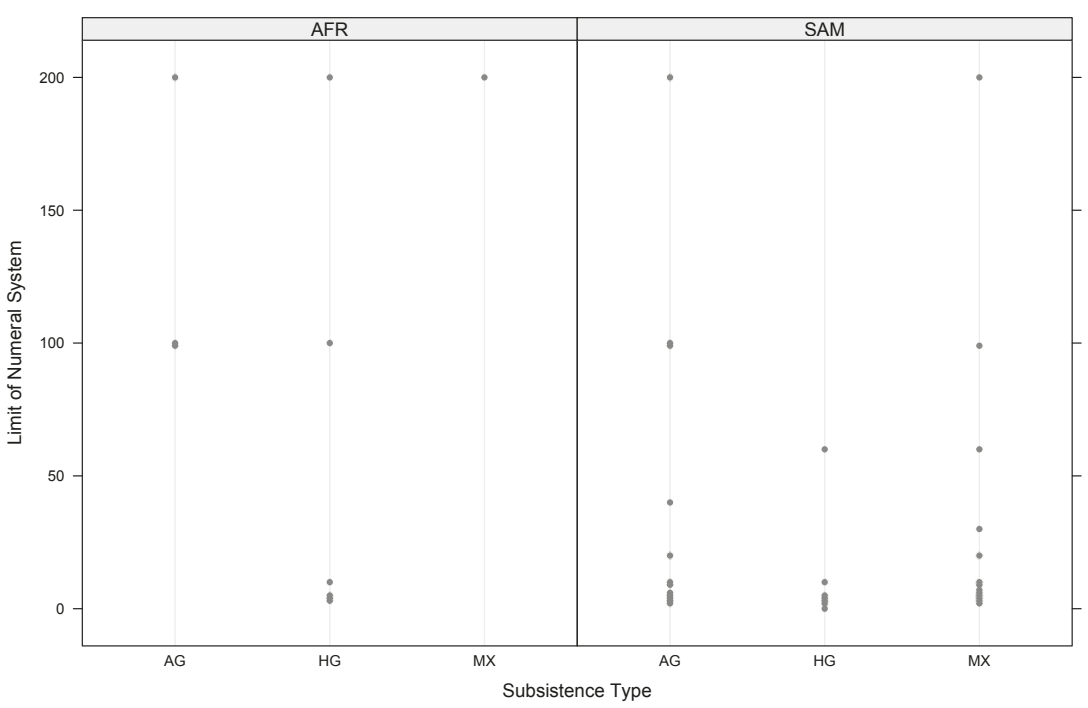

Figure 2. Numeral system limits and subsistence patterns in South America and Africa (the uppermost point on the y-axis represents values of 200 or beyond; $A G=$ agriculturalist, $H G=$ hunter-gatherer, $M X=$ mixed subsistence)

subsistence groups surveyed have quite high limits, ranging from 99 or 100 to far into the thousands or even beyond (Figure 2). The differences between the distributions across the two regions are also interesting; in South America, it is the relatively agricultural groups that exhibit a range of numeral system limits, while the hunter-gatherers are more uniform; in Africa, we see the reverse.

For the South American and African languages, we note that although many of the languages within our sample are not independent due to genetic relationship, membership in the same family is not in itself a predictor of limit type, especially for the larger and older families. In South America, a hunting-gathering subsistence focus is largely consistent within families (notably Yanomami, Nadahup, Kakua-Nukak, and Guahiban); these languages all tend to low limits. Among more agriculturally oriented language families, an association between numeral limits and language family is significant in some cases (particularly in relatively shallow families such as Tukanoan, favoring limits between 10 and 20, and Quechuan, with limits mostly well over 20) but not for others (such as Arawak, Carib, Pano), in which attested numeral limits vary more widely across member languages. In Africa, many of the language families are distributed between hunter-gatherers and agriculturalists/pastoralists (particularly Khoe, Ubangian, and Bantu within our sample), but numeral limits vary widely within these families. 
As a final note, we observe that patchiness of data is unlikely to give rise to systematic biases corresponding to non-numeral factors. For the most part, there is no apparent reason to suppose that the individuals who documented these languages were more or less likely to record higher numerals, if they existed at the time, depending on geographical region, subsistence pattern, etc. although there is the possible caveat that some researchers may have associated low numeral systems with stereotypical views about "primitive" languages and did not fully explore system limits. There is also no evidence to suggest that regional or subsistence factors contributed to the replacement of native terms with European numerals (resulting in the truncation of native systems) in the main case-study regions considered here. ${ }^{14}$ In South America, for example, we would actually predict that agriculturalists' languages would be more prone to European influence, because agriculturalists' relatively sedentary, river-based existence has been more conducive to interaction, but in fact we find that the higher-limit systems are predominant in these languages and not in those of the hunter-gatherers.

\subsection{Extent of atomic native numeral terms}

We consider the upper limit of "atomic" native lexical items in a numeral system as a factor associated with numeral complexity, particularly regarding its change over time. Lexical items of this kind are defined as monomorphemic roots that are NOT transparently derived (either historically or synchronically) from a word that means something other than this precise quantity (i.e., a nonnumeral term or a distinct numeral base), and are not loans from another language. ${ }^{15}$ The limit of such terms is defined as the end of a sequence, with no gaps consisting of more than one intervening term that is not itself an "atom". For example, in some East Tukanoan languages in the Amazon, 1 to 3 are unanalyzable atoms (with no obvious etymological source), whereas 4 means literally 'have companion', 5 is literally 'one hand', and 6+ are complex terms involving added fingers/toes; thus the limit of atomic numeral terms in these languages is 3, although their overall numeral limit is higher (see Ramirez 1997, Aikhenvald 2002: 108). A relatively high limit to these underived lexical atoms is likely to reflect a more established, older degree of numeral complexity in a given language, because etymological transparency tends to be obscured over

14. In southeast Asia, on the other hand, the replacement of numerals by borrowing from other regional languages may indeed be an areal trend.

15. Some terms for 1 in our sample (particularly in Australia and Amazonia) have alternative meanings such as 'alone', 'together', 'other', but since it is not known whether the numeral or alternate meaning is primary these are not counted as historically derived. In most other cases, etymological transparency is taken as evidence that the numeral meaning has emerged from a distinct source. 
time and/or through frequent use via the processes of lexicalization that affect linguistic expressions in general (as in God be with you > goodbye; see, e.g., Crowley \& Bowern 2010).

Interestingly, the hunter-gatherer languages in all four case study regions tend to relatively low upper limits of underived native lexical items, as Figure 3 illustrates; nevertheless, some variation across regions exists. In Australia, all numeral terms in the system are lexical atoms in $32 \%(n=39)$ of the languages surveyed; that is, these systems do not undergo a transition from a series of atoms to one of derived/loaned forms. ${ }^{16}$ Within the full sample, the limit of atomic terms is in most cases either 2 or 3 . Other upper limits to underived terms are $1(n=6), 4(n=7), 5$ (the Pama-Nyungan language Wirangu), and 8 (the Pama-Nyungan language Kaurna).

In the California/Great Basin region, in contrast to the higher overall limits attested in the majority of numeral systems, the upper limits of numeral atoms in hunter-gatherer languages cluster at $2(28 \%, n=10)$ and $4(42 \%, n=15)$. Other upper limits to numeral atoms are 1 (the isolate Esselen), $3(n=4), 5$ $(n=4)$, and 6 (the isolate Washo). ${ }^{17}$

In South America, numeral atoms in the majority of the hunter-gatherer languages for which reliable data exist have an upper limit of $2(62 \%, n=8)$. Others have 1 ( 2 languages of the Nadahup family), 3 (the isolate Yámana), and 4 (the Arawak language Iñapari).

Among the African hunter-gatherer languages, all numeral terms in the system are atoms for about half $(n=8)$ of the sample. The range of atomic limits tends on the whole to be somewhat higher than that found in the three other regions, but is variable, from 2 ( $12 \%$ of the hunter-gatherer languages, $n=2)$, $3(29 \%, n=5), 5(35 \%, n=6)$, and $10(24 \%, n=4)$.

In comparison, the native systems found in the small set of Northeast Asian languages investigated are variable but tend to be relatively high, with atomic numeral limits of 4 (Ainu), 7 (Ket and Yukaghir), and 10 (Nivkh). ${ }^{18}$

On the whole, the limits of numeral atoms for hunter-gatherer languages vary less across the four focal regions than do the limits of numeral systems more

16. Note that we do not include more recent augmentations/substitutions of systems using European numerals, as discussed in Section 4.3 below.

17. Interestingly, the simpler Seri system has an upper "atomic" limit of 9, despite its lower overall limit (10), whereas numeral "atoms" in the more complex system are limited to 5. This may be a further indication that the simpler system is the older one. It also raises the question of whether the elaboration of productivity via the adoption of bases may in certain cases supplant earlier atoms, such that an increase of complexity along one parameter leads to a decrease along another (we thank Victor Golla for bringing up this point; personal communication to Jane J. Hill).

18. The Aslian languages to the south have preserved earlier Mon-Khmer "atoms" for 1 (Jahai) and 1, 3, 5 (Semelai), while the rest of their numerals are Austronesian loans. 


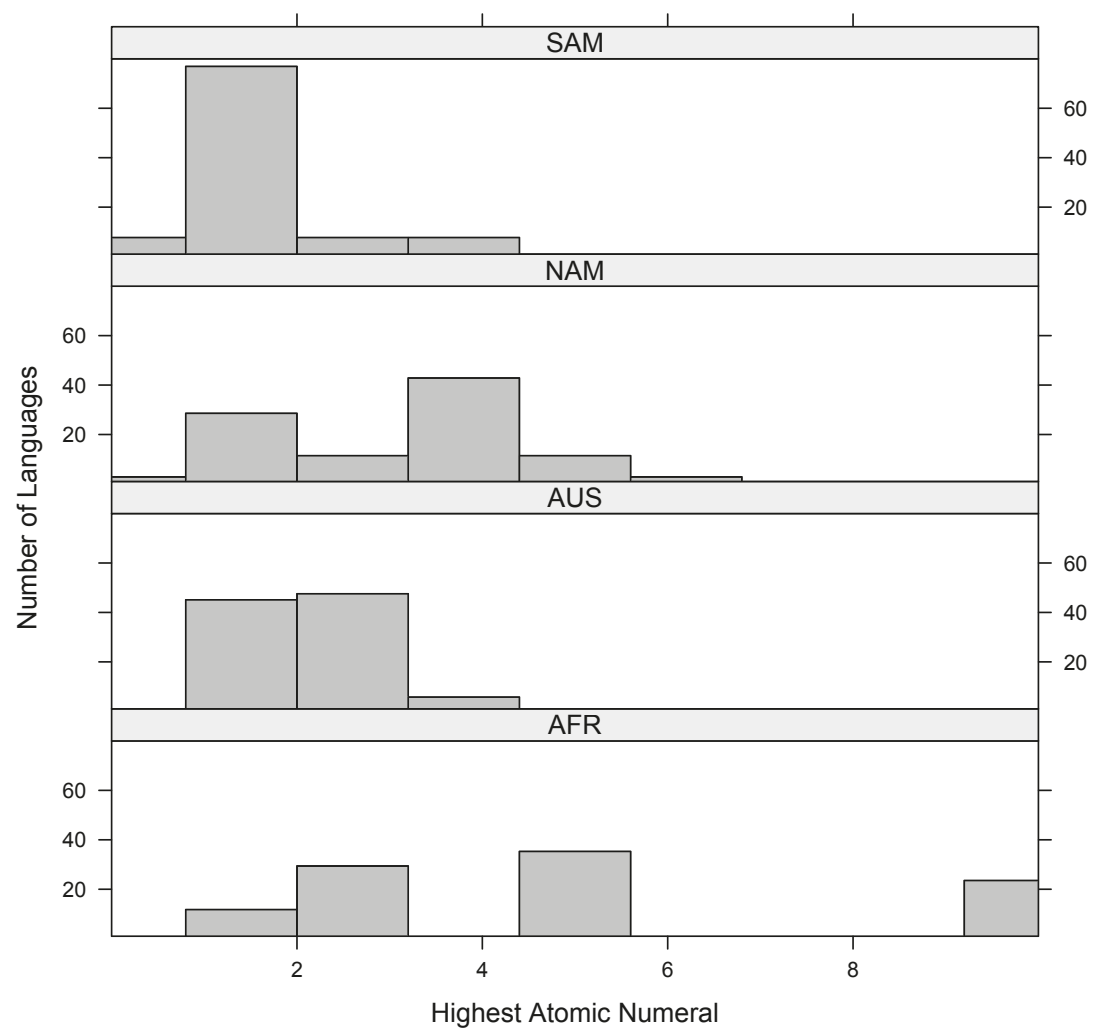

Figure 3. Highest atomic native numeral in hunter-gatherer languages

generally. The same is largely true within these regions: hunter-gatherers do not deviate dramatically from the wider areal patterns, although they do tend to somewhat lower limits. In California and the Great Basin, the limit of atoms in the twenty-one additional languages surveyed from agriculturalist/mixed subsistence groups clusters around 2 and 4 - as is also true for the hunter-gatherers - although an additional eight languages also exhibit limits between 6 and 10 (and one, the Uto-Aztecan language Hopi, appears to have a limit of 20, though several of the intervening forms are etymologically transparent). ${ }^{19}$ In South America, limits for numeral atoms cluster around 2 and 3 for agriculturalist and mixed-subsistence groups, with several more at 4 (while hunter-gatherers are predominantly at 2); again, it is noteworthy that the Quechuan languages

19. For 11 to 19 , Hopi also employs a different set of numeral terms for modification that are base-10; the atomic variants are used primarily in counting. 
- the primary representatives of a strongly stratified, state society - tend to be quite distinct, with limits of 10. In Africa, the non-hunter-gatherer languages all exhibit atomic limits of 5 or above, as do $59 \%$ of the hunter-gatherers. Those African languages attaining an atomic limit of 10 (although in a few cases the sequence is interrupted by a non-atomic word for 9) comprise $60 \%$ of the non-hunter-gatherers and $24 \%$ of the hunter-gatherers.

A high limit to numeral atoms is obviously restricted by the overall limit of a numeral system (in other words, if there are no numerals over 3, then there will be no numeral atoms above 3 ). However, high system limits are not strongly associated with high limits of lexical atoms across much of our sample, particularly in the Americas. ${ }^{20}$ This lack of a clear correlation is most striking for the languages of the North American sample, which tend to have relatively high upper system limits but low limits to lexical atoms. These facts suggest that the elaboration of complexity in many of the North American numeral systems was a relatively recent event.

A lack of a strong correlation between system limits and atomic limits is also true of the South American sample, in which roughly half of the languages having the relatively high limits (compared to other languages in the region) of 3 or 4 to their numeral atoms are found in languages with overall numeral limits of 5 or below. There are nevertheless a few exceptions to these trends in the Americas, particularly the Quechuan languages in South America and the agriculturalist Kiowa-Tanoan languages in North America, which display both high system limits and high atomic limits.

Although our sample for Africa is more limited, it shows a somewhat distinct pattern from that seen in the Americas. All of the languages surveyed in this region that have high system limits (of 99 or 100 and higher) also have high atomic limits (5 or above, with over half having an atomic limit of 10). The same trends appear to hold among the Asian languages surveyed as well (with the marginal exception of Ainu, which has an atomic limit of 4).

\subsection{Variability of bases}

The variability of bases used in numeral systems is a further factor associated with numeral complexity. Following Comrie (2011) we define "base" here as "the value $n$ such that numeral expressions are constructed according to the pattern $x n+y$, i.e., some numeral $x$ multiplied by the base plus some other numeral y" (or of the more simplified form $x n$ or $n+y$ ). ${ }^{21}$ In keeping with this

20. The issue is not relevant for Australia, where system limits are uniformly low.

21. This definition is better suited to languages with low numeral limits than is the definition given in Hammarström (2010: 15), which makes reference to a higher base than the one being defined. 
definition, a given language may employ multiple bases; typically, the highest base used is the most productive (i.e., is used to form the largest number of other numeral terms), whereas an "alternative base is used only in the construction of a small proportion of relevant numerals" (Comrie 2011). Clearly, higher bases (10 or 20) are likely to occur in relatively more complex systems having more productive power, whereas lower maximum bases (such as 2 or 3 ) are more common in lower-limit systems. ${ }^{22}$

An example of a system with a maximum base of 2 is Garrwa (Furby \& Furby 1977) and an example for a maximum base of 5 is Tukano (Ramirez 1997: 332); see (4) and (5), respectively.

$\begin{array}{ll}\text { Garrwa (Garrwan, Australia) } & \\ \text { kujarra } & \text { '2' } \\ \text { kujarra-yalkunyi } & \text { ' } 3 \text { ' ('2 } 2+1 \text { ') } \\ \text { kujarra-kujarra } & \text { '4' ('2 } 2+2 \text { ') } \\ \text { kujarra baki kujarra yinamali } & \text { '5' ('2 and } 2+1 \text { ') } \\ \text { kujarra baki kujarra baki kujarra } & \text { ' } 6 \text { ' ('2 and } 2 \text { and 2') }\end{array}$

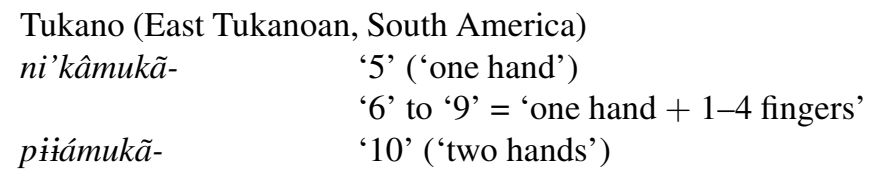

A language that employs more than one base is Wintu (Pitkin 1985), which uses bases 3, 4, 10, and 20; see (6). Lower-level bases may appear in as few as one or two other numeral terms (as in Wintu); in other words, according to our definition of base, these need not be productive within a given numeral system (although they may have been more productive in the past before a system was elaborated).

22. We do not include high-level terms for 100, 1000, etc., which frequently form a kind of base for still higher numeral terms, where these exist (e.g., English one hundred twenty). This decision is in keeping with convention, and also facilitates comparability within our sample, especially given the patchy availability of detailed information about such high-level numeral terms. We also do not consider the ordering of components within numeral terms (e.g., German hundertundeinundzwanzig $[100+(1+20)]$ vs. English a hundred twenty-one $[100+(20+1)])-$ although, as a reviewer points out, the inconsistent ordering of larger and smaller elements within the German expression involves more complexity than the consistent ordering in the English term. 
(6)

$$
\begin{aligned}
& \text { Wintu ("Penutian", California) } \\
& \text { рапих ' } 3 \text { ' } \\
& \text { ' } 6 \text { ' = 'twice } 3 \text { ' } \\
& \lambda \text { 'aw ' } 4 \text { ' } \\
& \text { ' } 8 \text { ' = 'twice 4' } \\
& \text { tiqeles ' } 10 \text { ' } \\
& \text { ' } 5 \text { ' = 'half, one side' } \\
& \text { ' } 9 \text { ' = 'minus one' } \\
& \text { ' } 11 \text { '-' } 19 \text { ' = ' } 10+1-9 \text { ' } \\
& \text { ' } 50 \text { ' = 'half } \times 10 \text { ' } \\
& \text { k'ete wint }{ }^{h} \text { un '20' (lit. 'one person') } \\
& \text { ' } 30 \text { ' = ' } 20+10 \text { ' (alternatively, ' } 3 \times 10 \text { ') } \\
& \text { ' } 40 \text { ’ = ' } 2 \times \text { person' (or ' } 4 \times 10 \text { ') } \\
& ' 60 \text { ' }=\text { ' } 3 \times \text { person' } \\
& ' 70 \text { ' }=\text { ' } 3 \times \text { person }+10 \text { ' } \\
& \text { ' } 80 \text { ' = ' } 4 \times \text { person' } \\
& \text { ' } 90 \text { ' = ' } 4 \times \text { person }+10 \text { ' }
\end{aligned}
$$

The presence of multiple bases may be a clue to elaboration in the history of a numeral system; i.e., a layering of a higher-base strategy with higher productive potential (e.g., base 5 or 10), onto an earlier strategy with lower potential (e.g., base 2); see Swadesh (1971: 188), Hurford (1987: 274), and also Epps (2006, for discussion of this process in the Nadahup languages of Amazonia). This layering process has undoubtedly occurred in some of the North American languages sampled; in at least some cases, there is evidence that restructuring was motivated by European contact during the period of missionization in the late eighteenth to early nineteenth centuries (e.g., in Chumash, see Beeler 1986). Some languages have as many as three or four identifiable (largely nonproductive) bases, as does Wintu. It is likely that the actual number of bases in use may be slightly higher than the figures below convey, due to limited documentation.

We turn first to the upper values of bases attested in the numeral systems under investigation. These values vary considerably both within and across the focal regions (see Table 1). In Australia, a high proportion of the languages surveyed do not use any base at all $(39 \%, n=47)$. A large number of others use base 2 to construct at least one additional numeral term $(57 \%, n=70)$. In addition, there are a few languages that use an uppermost base of 3 (the PamaNyungan language Adnyamathanha), 4 (the Pama-Nyungan language Kaurna), and 5 ( $n=2$, the Pama-Nyungan languages Muruwari and Gamilaraay).

In the California/Great Basin region, most of the hunter-gatherer languages surveyed have a highest attested base of $10(63 \%, n=20)$. Several $(16 \%$, $n=5$ ) employ a highest base of 20 (Yok-Utian, Uto-Aztecan, others; see Farris 
Table 1. Highest base attested in hunter-gatherer languages

\begin{tabular}{ccccc}
\hline Highest Base & Australia & North America & South America & Africa \\
\hline 0 & 47 & & 12 & 9 \\
2 & 70 & & & 2 \\
3 & 1 & 3 & & \\
4 & 1 & 1 & & 1 \\
5 & 2 & 20 & & 6 \\
10 & & 1 & & \\
16 & & 5 & & \\
20 & & 1 & & \\
25 & &
\end{tabular}

1990). Of the remaining languages, others employ a highest base of 4 (three Chumashan languages), 5 (the Uto-Aztecan language Gabrielino/Tongva), 16 (the Yukian language Yuki), or 25 (the Uto-Aztecan language Luiseño). ${ }^{23}$

Of the other regions sampled, some two-thirds of the nineteen South American hunter-gatherer languages use no base at all $(n=12)$, while the rest $(n=7)$ use base 5. Just over half $(n=9)$ of the African hunter-gatherer languages likewise have no base; of the rest, one uses a highest base of 2 , one of 5 , and the remaining six languages have a highest base of 10. In Asia, the borrowed Austronesian systems are base 10; in the northeastern languages, we find uppermost bases of 10 (Nivkh and Yukaghir) and 20 (Ket and Ainu).

In general, higher uppermost bases correspond to higher upper limits to numeral systems - as expected, given that higher bases impart more productive power to a system. Thus the variation in uppermost bases across the four focal regions corresponds closely to the variation seen in upper system limits. Within regions, variation relating to subsistence pattern is consistent with the generalizations made above for overall system limits. In California and the Great Basin, agriculturalist languages (like those of hunter-gatherers) favor base 10, with a few attestations of bases 5 and 20; this preference for decimal systems is reflected for North America generally, see Comrie 2011). Uppermost bases among South American mixed subsistence and agriculturalist languages cluster at 0 and 5 , as do those of the hunter-gatherers, although proportionally a few more non-hunter-gatherer languages favor 5 (42\% vs. $32 \%)$. Uppermost bases of 2, 3, 4, 10 (including most Quechuan languages), and 20 are also attested. The African sample shows a more pronounced difference relating to

23. The simpler Seri system has no attested base at all, uniquely among the North American languages considered here (including the more complex Seri system, which has a highest base of 10 and additional unproductive bases of 5 and 2). 
subsistence, but corresponding closely to system upper limits; all of the nonhunter-gatherer languages have a highest base of 10 (and high upper system limits); the same is true for only $35 \%$ of the hunter-gatherers, whereas the majority of these languages have no base at all (and low system limits of 5 or below).

We turn next to the existence of multiple bases (of which only the uppermost is typically productive), as illustrated in Figure 4. Multiple bases are very limited in Australia; only two languages in the sample have more than one attested base: Gamilaraay and Muruwari (Pama-Nyungan, Macro-Central New South Wales) each have three bases, with lowest 2 , intermediate 3 or 4 , highest 5 , and with an upper system limit of 20 or 10 , respectively. ${ }^{24}$

In the California/Great Basin region, in contrast, of the hunter-gatherer languages for which adequate data are attested $(n=30)$, a high proportion $(73 \%$, $n=22)$ have more than one base. ${ }^{25}$ Many $(n=10)$ have three bases, and a few languages have four (the "Penutian"' language Wintu, see (6) above, and the Uto-Aztecan language Tübatulabal) or even five (the Uto-Aztecan language Serrano). About half of the languages with multiple bases $(n=16)$ have a lowest base of 2, 3, or 4, and many use intermediate bases as well; their highest base is in most cases 10 . The rest have a lowest base of 5 (with highest base of 10,20 , or 25), and one language has a lowest base of 6 . A few further traces of a non-productive base 6 were detected in this region - noteworthy given the crosslinguistic rarity of senary systems (see Beeler 1961, Plank 2009, Hammarström 2010).

Elsewhere in the world, we find that only one of the nineteen South American hunter-gatherer languages sampled has more than one base (2 and 5) Huaorani, which also is the only hunter-gatherer language with an overall limit above 10. Multiple bases are likewise rare among the African hunter-gatherer languages, of which only two of those sampled $(n=17)$, Sandawe (isolate) and Bayanga Aka (Bantu C10), have more than one base (5 and 10). The Asian languages investigated tend to have one base (and favor a decimal system), but Ket and Ainu use base 10 up to 20, then base 20 .

In comparison with broader regional trends, we again find little difference between hunter-gatherers and others in the California/Great Basin region, where most languages have between one and three bases regardless of subsistence pattern. In South America, $20 \%(n=30)$ of mixed subsistence and agriculturalist groups have more than one base (most of these have two bases, but three languages have three, viz. the Arawak language Palikur, the

24. A few others have an additional term for 10 (based on 5) but apparently lack the intervening sequence 6 to 9. Data are uncertain on this point.

25. However, a number of these are etymologically semi-opaque, and are not necessarily obvious to speakers. 


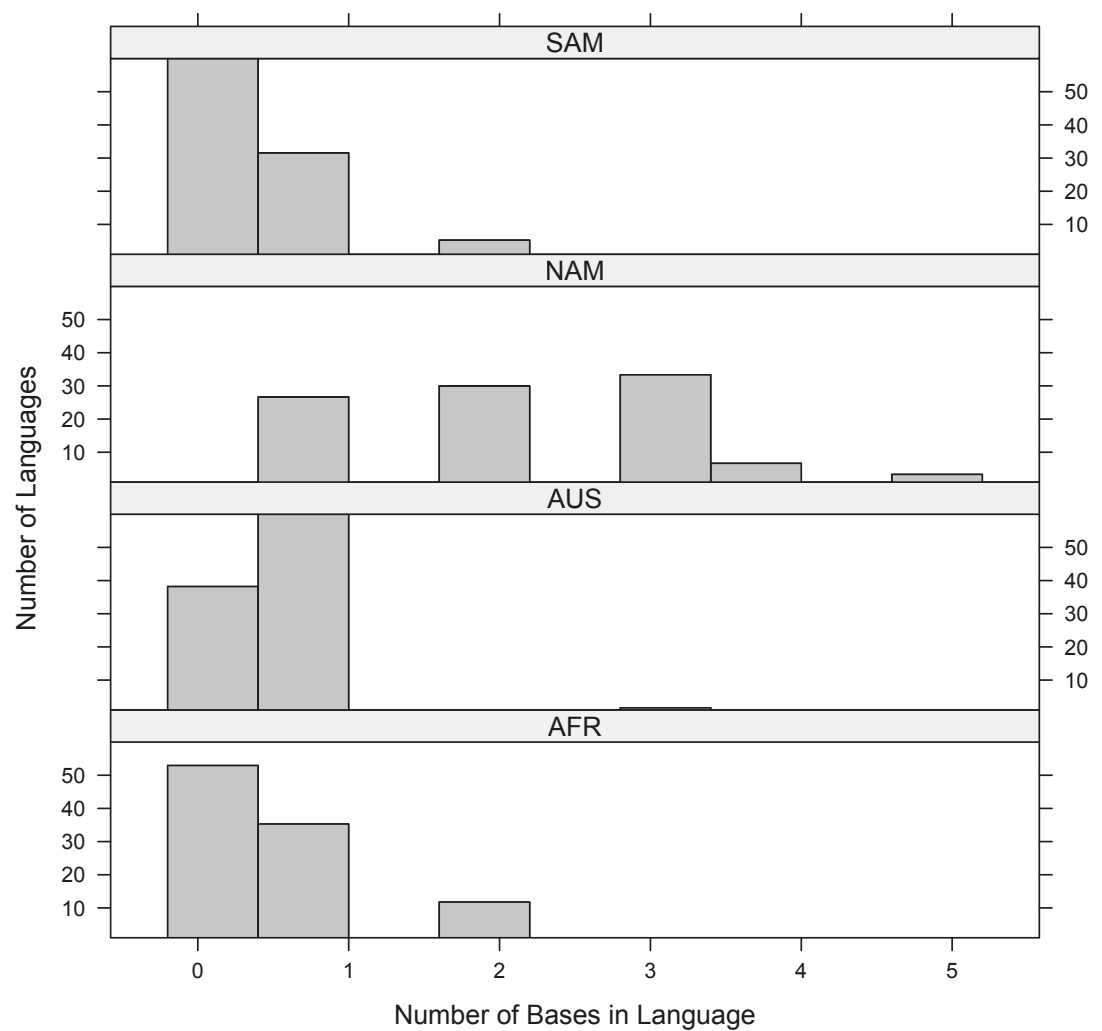

Figure 4. Existence of multiple bases in hunter-gatherer languages

isolate/unclassified language Puinave, and the isolate Andoke), as opposed to only one hunter-gatherer language (Huaorani); this is clearly dependent on the tendency for low overall system limits among the hunter-gatherers. In Africa, six $(40 \%$, and marginally a seventh) of the non-hunter-gatherer languages have two bases, as do two (12\%) of the hunter-gatherer languages, also in keeping with higher upper system limits.

To summarize these results, the patterning of bases tends to correspond roughly to that observed for the limits of systems, with some regional variation. Australian languages (with their overall low limits) are particularly likely to have no or only one base (usually base 2), whereas two-thirds of California/Great Basin languages (which tend to much higher limits) have multiple bases (of which the highest and most productive is predominantly base 10). South America is more variable, with over a third of the total languages sampled having no attested base (predominantly those with low limits), about a 
fifth having two (or in a few cases three) bases, and base 5 typically the highest used; however, hunter-gatherer languages in this region have predominantly zero to one base only. In the African sample, most low-limit systems (of which all occur among hunter-gatherers) use no base, whereas higher-limit systems have predominantly one to two bases (of which the highest is base 10). As noted above, the exuberant layering of bases seen in the North American sample (and to a lesser degree in the South American one; see Epps 2006) may indicate a relatively recent elaboration of some systems.

\subsection{Numerals and sociocultural parameters}

As we have seen here, and as evidenced in other typological surveys of numeral systems (such as Comrie 2011 and Hammarström 2010), numeral complexity has a strong areal component. Thus, while we may observe that restricted systems tend to cluster in regions in which hunting and gathering are focal subsistence practices (Australia, South America, southern Africa), it is difficult to tease out the relevance of subsistence, as opposed to other regional trends, to numerosity. Moreover, the fact that relatively complex numeral systems exist widely among hunter-gatherers in North America, Siberia, and other parts of the world indicates that agriculturally oriented subsistence is not required for the development of numeral complexity. However, a comparison of numeral variation WITHIN regions where subsistence focus varies and restricted systems are widely attested - i.e., South America and Africa, but not Australia and North America - suggests that a meaningful correlation between numeral complexity and subsistence may in fact exist. In these regions, as discussed above, numeral complexity (as measured by the parameters considered here) is predominantly lacking in hunting-gathering groups, whereas more agriculturally oriented groups range from more to less restricted in South America, and tend to high upper limits in Africa. Nevertheless, as our results also show, even relatively simple numeral systems may exhibit a wide range of variation.

Our findings suggest that, while the presence of agriculture itself does not directly drive the development of numeral complexity, it may well be associated with other aspects of social organization that, at least in some cases, foster numeral elaboration. Exactly what these may be is not yet clear, however. Among the variables associated with subsistence pattern is relative mobility (nomadic, semi-nomadic/seasonal, sedentary); in the languages surveyed, this was found to correlate closely with subsistence pattern, although there are various exceptional cases of settled foragers, such as the Seri of Mexico, who depend heavily on sea life. Relatively small population size and density are other potentially relevant factors; however, population estimates are unfortunately available only for contemporary populations in much of our sample (particularly in South 
America), and are almost certainly very different from figures predating European contact.

A likely variable associated with numerosity is exchange. Hunter-gatherers around the world are widely involved in trade, but there may be significant differences in the scale, scope, and delayed vs. immediate nature of exchange, themselves relating to social network structure, division of labor, food storage practices, etc. Trade-focused interaction of hunter-gatherer groups with agriculturalists has been shown to correspond to the elaboration of numeral systems in at least one case (the Nadahup languages of Amazonia, see Epps 2006); compare also the borrowing of non-hunter-gatherer numerals among the Aslian groups in Asia and among various South American languages in contact with Quechua. However, the sample size relating to documented cases of high interaction between hunter-gatherers and other groups is small in our survey, so we must leave this question for future research.

It is similarly important to ask why hunter-gatherers in other parts of the world, such as North America and Siberia, have developed complex numeral systems - clearly, agriculture is neither a necessary nor a sufficient condition for numeral elaboration. Complex exchange practices may develop among hunter-gatherers as well as agriculturalists, as evidenced by California/Great Basin peoples' use of shell money (Loeb 1926). Other localized practices may also contribute to a need for numerals, such as astronomical observation, reindeer herding, and perhaps even highly detailed basketry such as that found among the California/Great Basin peoples. A more nuanced understanding of the dynamics of numeral elaboration will be best informed by a fine-grained level of ethnographic study.

\section{Historical development of numeral systems}

\subsection{Traces of change}

The numeral systems examined here - largely understudied and exhibiting a wide range of complexity - are a rich source of insights into the dynamics of numeral elaboration over time. In particular, etymological transparency offers important clues into these processes. As noted above, such transparency tends to be obscured over time by the processes of lexicalization and phonological reduction that are general in language; thus the origins of low-level terms in particular are often opaque in older, more established numeral systems. Systems that have experienced relatively recent elaboration or renovation are more likely to reveal traces of these processes. ${ }^{26}$ As discussed above, a detectable

26. The tendency for processes of language change to become obscured over time is a generalization that guides historical methodology (see, e.g., Crowley \& Bowern 2010); however, we recognize that relative transparency cannot be taken as definitive proof of recent change, because rates of change are not constant across languages or linguistic elements. 
layering of bases can reflect stages by which a numeral system has built up its productive power; such layering is most apparent in the North American case study region, where restructuring occurred in at least some languages due to European influence, and in others may well have preceded this contact. Similarly, low upper limits of "atomic" or opaque native numeral lexical items may also suggest a relatively recent elaboration.

In the following discussion, we focus on the historical sources of numerals in the lower ranges of systems. In the upper ranges (typically above 5, 10, or 20), numerals tend to owe their forms to the productive use of bases; in the lower ranges, however, terms are more likely to derive from other processes of lexical innovation or borrowing, and thus are less predictable. Traces of these processes provide insights into how numeral systems develop in languages generally, and inform our understanding of the numeral histories of particular languages.

\subsection{Etymological sources of numeral terms}

The sources of low-level numeral terms are obscure in many of the world's better-studied languages, which tend to have opaque terms below 5 or 10 . Yet in some of the numeral systems surveyed here, etymological sources of these low-level terms are still easily detected, often innovated from non-numeral sources. ${ }^{27}$ As with the parameters examined above, however, we see considerable variation across case study regions, with numeral etymologies particularly visible in South America.

The Australian systems are broadly consistent in revealing few non-numeral etymological sources (see Bowern \& Zentz 2011). Terms for 1 are often related to other words meaning 'together' or 'alone', but (as noted in Section 3.1 above) it is not clear whether the numeral is derived from the other meaning, or vice versa. Words for 2 in our sample are all opaque (although a number are loans, see below), except in a few cases where they are associated with terms meaning 'pair' or a dual marker - but again, the direction of derivation in such cases is not clear, and both terms are quantitative. Terms for 3 to 4 and above are frequently derived from 2; non-numeral sources are limited to the term for 3 , *kulparri, in the Karnic subgroup of Pama-Nyungan, which has been reconstructed to 'emu', undoubtedly motivated by the bird's three large, splayed

27. Numeral sources (e.g., '2 and 2' for '4') are also addressed above (Section 3.4). 
toes (Luise Hercus, personal communication to Bowern). ${ }^{28}$ Where terms for 5 to 10 exist, these are usually based on 'hand', and terms for 10 to 20 on 'foot'; crosslinguistically, these are typical sources for these values.

The languages of California and the Great Basin also reveal few non-numeral etymological sources. Terms for 1 to 3 are opaque in all languages of the sample, except for a doubtful link between 3 and 'big' in some members of the Uto-Aztecan family. Terms for 4 are derived from 2 in a number of languages in the sample, and Comanche 4 may derive from 'last-exact'. A common source for terms for 5 is 'hand' (attested in over half the languages sampled, of both hunter-gatherers and agriculturalists), and complex terms for 6 to 9 typically involve other numerals (as bases) and/or reduplicated forms, with the (partial) exception of Seri 6 'chest/breast +1 '; terms for 10 typically derive from other numerals or 'hand'.

Similarly, few non-numeral etymological sources for low-level numerals were encountered in the African and Asian languages surveyed. In Africa, numeral terms above 5 in several Bantu languages relate to fingers (see also Schmidl 1915, Zaslavsky 1973, Zerbian \& Krifka 2008), as do most terms above 3 in Khoe languages. The term for 3 in Ju|'hoan (Kx'a) may be related to the word for 'clay pot', and 2 in Baka (Ubangian) may derive from 'friend, brother'. Among the Asian languages considered, Ket, Ainu, and Yukaghir use additive or subtractive strategies for some or all terms between 6 and 9; in Ainu 5 is derived from 'hand' and 10 from 'two sides'.

The South American languages are the most intriguing from the perspective of numeral etymologies (see Epps \& Hansen 2011 for detailed discussion). In addition to terms derived from other numerals, as seen in the other case study regions, we find a range of distinct etymological sources for low-level numeral terms. These tend to derive from features of the natural or cultural world that have a particular number of salient components, although their motivation is not always obvious. As in Australia, terms for 1 are frequently related to 'alone' or to demonstratives, but the direction of derivation is unclear. Sources for 2 include 'eye' in Hup (Nadahup) and Gavião (Tupí), 'deer footprint' in Xerénte (Je), 'help' in Urarina (isolate), and 'proliferate' in Matses (Pano). Among terms for 3, we find 'rubber-tree-seed' in Nadahup languages, 'rhea bird footprint' in Xerénte (Je; the rhea bird has three distinctive toes), 'jar support' in Yucuna (Arawak; probably a reference to stones or clay pedestals placed in a fire in sets of three), and 'pronged fishing arrow' in Hixkaryana (Carib family). More predictably, analyzable terms for 5 and above almost always involve hands, fingers, and feet.

28. Other non-numeral sources may exist, but it is striking thus far that numeral terms in Australia are not only unreconstructable beyond low-level subgroups, but are frequently unetymologizable. 
A particularly intriguing feature of the South American numeral etymologies is found in terms for 4 , of which a remarkably high proportion in our sample derive from terms involving a social relationship - usually 'sibling' or 'companion' (7), but in a few cases 'spouse' or even 'enemy'; see Epps \& Hansen $2011 .{ }^{29}$ In several languages, "relational" terms for 3 and/or 5 also exist, possibly formed by analogy with 4 .

$$
\begin{aligned}
& \text { a. Murui (Witoto) } \\
& \text { naga ama-ga '4' = 'each brother' } \\
& \text { b. Hup (Nadahup) } \\
& b a b^{\prime}-n i \\
& \text { c. Suyá (Je) } \\
& \text { ajmen ndo krám wiri ' } 4 \text { ' = 'each with only one companion' } \\
& \text { '4' = 'sibling exists/accompanied' }
\end{aligned}
$$

Relational numeral terms were identified in $26 \%(n=49)$ of the total number of South American languages surveyed, including several spoken by huntergatherers. These languages are scattered widely throughout the Amazon basin and occur in at least thirteen different families. Because a comparable source for 4 (or other numeral terms) is virtually unattested outside the region, language contact (probably involving calquing) is a likely vehicle of spread (see also Epps 2006). Only a few alternative (non-numeral) sources for 4 are attested in the region, such as 'shoulder blade' in Yucuna (Arawak).

We find no evidence here for a correlation between non-numeral etymological sources and subsistence pattern. While it is likely that some association exists between transparent non-numeral sources and simple numeral systems, this is not apparent from our sample. Etymological sources are easily identified only in South America, where the majority of the languages surveyed have limits of 20 or below; in Australia, in contrast, identifiable non-numeral etymological sources are very rare, despite the strong preference for low-limit systems.

\subsection{Borrowing of numeral terms}

Comrie $(1999,2005)$ notes the particular susceptibility of numeral systems to restructuring through language contact. Contact-induced changes may include restructuring of bases (e.g., Chumash in North America, see Section 3.4), calquing (as in the case of "relational" 4 in South America, see Section 4.2), and lexical borrowing of terms. Borrowing of terms or strategies is a common component of system elaboration, but loaned numerals may also replace native ones. In such cases, clues to the original limits of the native system may be

29. See also the discussion on the Etnolingüistica forum (http://lista.etnolinguistica.org/1898, February 2009; accessed March 2009 and November 2011). 
found in the maintenance of doublets (coexistent native and borrowed terms) or in sister languages that have retained inherited forms.

We consider the extent of loan numerals in the languages surveyed, with a focus on terms for 1 to 10 (which are most likely to be attested in the available data). We exclude calques and other forms of contact-induced restructuring, which are nearly impossible to detect consistently in a sample of this size. We also exclude loans from European-derived contact languages (Portuguese, Spanish, English, French, Afrikaans), because these often co-occur with native terms, are often left undocumented in the available sources, and because some contact with European languages is almost universal throughout the case study areas.

Borrowing of low-level numeral terms is attested throughout the sample, though to differing degrees. ${ }^{30}$ In Australia, terms for 2 and/or 3 show evidence of borrowing in a number of languages ( $16 \%$ of total languages, $n=20$ ); in particular, 2 was borrowed from Pama-Nyungan into Proto-Nyunyulan, Mirndi, and Garrwan, and 3 was also borrowed from Pama-Nyungan into several northern languages (see Bowern \& Zentz 2011). In North America, $20 \%$ $(n=11)$ of the total languages sampled have borrowed one to two numeral terms between 1 and 10 from a neighbor; for example, Chumash (Chumashan) appears to have been the source of words for 1 in several languages, and Sierra Miwok (Yok-Utian) has borrowed 5 from Uto-Aztecan. In South America, $6 \%$ $(n=11)$ of the total languages surveyed have borrowed numeral terms from Quechua, typically in series (e.g., 3+, 5+); all of these are spoken in regions bordering on Quechua (e.g., members of the Pano family). No other indigenous donor language was identified in South America. In Africa, $24 \%(n=4)$ of the total sample have borrowed one or more numeral terms between 1 and 10, and of these, Naro (Khoe) has reportedly borrowed a full series (4 to 10) from Khoekhoe (Visser 2001: 232). Among the Asian languages, as mentioned above, the Aslian groups have adopted their numeral systems almost wholesale from Austronesian, as has Agta via the process of language shift; in contrast, the northeastern languages show no evidence of loaned numerals.

It is possible that numeral borrowing is associated with subsistence pattern, but this cannot be ascertained from the existing sample. In South America the borrowed terms are found in relatively agricultural groups, but these peoples have probably been considerably more dependent on hunting and gathering than their Quechua donors. The loans in the North American and African samples are largely limited to hunter-gatherer languages, but more agriculturalist languages would need to be surveyed in order to determine whether this result is significant.

30. In the loan counts discussed here, doubtful cases were treated as $1 / 2$ a loan value. 
However, we can observe that the lower rate of borrowing in numeral terms in the South American languages is consistent with the relatively low loan rates in other vocabulary throughout this region, independent of subsistence pattern (see Bowern et al. 2011). It is also intriguing that the South American numeral terms show more evidence of lexical innovation at the same time as they experience limited borrowing; it is likely that these variations across the case study areas reflect different regional norms regarding the generation of new lexical items.

\subsection{Numeral histories in areal perspective}

The results of this study allow for some tentative generalizations about numeral system histories. Among Australian peoples, there appears to have been little need for talking about precise quantities, as evidenced by the generally low limits to systems and the prevalence of vague or ambiguous terms. Nevertheless, terms for 1 to 3 are widely present across the region and tend to be etymologically opaque, so the existence of a few basic numeral terms may be old (although these terms are not widely reconstructable).

In California and the Great Basin, the presence of at least the low-level numerals ( 1 to 5) also appears to have considerable time-depth, but it is likely that systems have undergone widespread, relatively recent elaboration, resulting in considerable complexity. Evidence for this scenario includes the low upper limits of underived lexical "atoms", the layering of multiple bases, and the generally high upper limits of systems. Golla (2011: 219) argues that in California " $[\mathrm{t}]$ he regular use of lexified higher numbers almost certainly had to await the development of an intergroup trading eonomy in which values were set in a standard, countable medium of exchange", that did not occur before 800-1000 CE. Results from the Comparative Method in Uto-Aztecan also support this proposal; only 1 to 3 reconstruct to Proto-Uto-Aztecan (Stubbs 2011). . $^{31}$

In South America, as in Australia, it is likely that numerosity has been of relatively low importance to many groups, as evidenced by the low limits to underived "atoms" in three-fourths of the languages surveyed, the existence of vague or ambiguous terms (though these are far fewer than those attested in Australia), and the low overall limits in over one-third of the languages sampled. A number of groups - most of which are agriculturally focused peoples, as opposed to hunter-gatherers - have nonetheless elaborated their numeral complexity, as can be seen in their higher upper limits, some layering of bases, and the frequency of derived terms for 5 and above. Some of this elaboration

31. The root *ma:- 'hand' also occurs widely in Uto-Aztecan words for 5 and 10, but the full terms do not reconstruct except to the lowest levels of subgrouping. 
and/or restructuring has involved contact with other groups - evidenced by calquing, e.g., of "relational" terms for 4 , but only minimally by lexical borrowing; languages have also frequently used their own resources, as indicated by the high levels of etymological transparency in low-level numeral terms.

Numerals appear to have been widely present in the African languages. The opacity of low-level terms, general absence of vague/ambiguous terms, lack of much layering of bases, and high-limit systems in many languages suggest some time-depth (particularly for low-level numerals) and do not point to a particularly recent elaboration of the more complex systems. As noted above, several of the hunter-gatherer languages with low numeral system limits are related to other languages with much more extensive systems, in many cases spoken by agriculturalists/pastoralists (notably of the Bantu, Ubangian, and Khoe families); in the Bantu and Ubangian cases the hunter-gatherers have most likely experienced language shift at some time in the past. These facts raise the intriguing question of whether the agriculturalists' systems were elaborated, or whether instead the hunter-gatherer systems underwent a reduction of complexity over time (i.e., atrophied due to lack of regular use). In the case of Bantu, synchronic and diachronic evidence support an earlier quinary counting system (synchronically, some languages like Chichewa use 5 as a base for numerals between 5 and 10, while others show that numerals 1 to 5 are a unified class morphosyntactically but numerals 6 to 10 behave differently; diachronically, only terms through 5 reconstruct for Proto-Bantu; see Zerbian \& Krifka 2008, Meeussen 1967: 105), suggesting that the lower-limit systems in these hunter-gatherer languages may have simply avoided elaboration, while those of their agriculturalist neighbors were expanded. Further research into the histories of numeral terms in these languages will shed light on these questions.

Finally, while our Asian sample is much more limited, it suggests that numeral complexity is relatively well established among northeastern/Siberian hunter-gatherers (see also Hammarström 2008). The southeastern peoples surveyed have altered their systems almost entirely through contact; the extent to which these changes involved replacement or augmentation of prior systems is not known.

\section{Conclusions}

Numerals are unlike many other linguistic categories in that their complexity varies widely across languages, and they are prone to culturally facilitated elaboration. The extent to which this development of numeral complexity correlates with subsistence pattern and/or other sociocultural parameters has long been a matter of speculation.

This study contributes a neglected area to the discussion of numeral typology. In considering numeral systems across 193 hunter-gatherer languages, dis- 
tributed across multiple continents, we observe that hunter-gatherer numerals vary widely on a number of parameters. Hunter-gatherer systems are by no means always small and simple; nor, when we compare the numeral systems of neighboring agriculturally focused peoples, do we find that these are always complex. Similarly, even restricted systems (like those common in Australia and South America) are diverse in their possibilities for numeral formation (see also Bowern \& Zentz 2011), with variation in relative productivity, bases used, and historical sources of terms. Patterns in numeral limits, values and multiplicity of bases, points of transition from "atomic" to derived numeral terms, etymological transparency in low-level terms, and proportions of loans tend to correspond primarily to large-scale geographic region, although there is considerable variation within these regions as well.

The variation across hunter-gatherer numeral systems worldwide indicates that subsistence practice is not itself a predictor of numeral system type. Nevertheless, there is some indication that numeral complexity and subsistence pattern may be associated, if only weakly. Because of the strong areal component to numeral patterns, such a correlation is best looked for within, rather than across, geographical regions. This is impossible in Australia, which has no native agriculture. We also find no evidence of a correlation in California and the Great Basin (nor does one appear likely in Northeast Asia/Siberia; see also Hammarström 2008, Comrie 2011). In South America and Africa, on the other hand, we do see a tendency for hunter-gatherer numeral systems to be relatively small (i.e., to have low overall limits, and corresponding low uppermost bases), whereas larger systems are more likely to be encountered among languages spoken by more agriculturally oriented peoples. However, restricted systems are also widespread among agriculturalist groups in South America (who typically practice some hunting and gathering as well); the small number of "pure" hunter-gatherer languages in this region - of which several are genetically related - makes it difficult at this point to establish whether a significant correlation exists.

The areality of numeral patterns, as well as the visible effects of contact in many systems (loanwords, calquing, etc.), suggests that hunter-gatherer numerals regularly experience changes motivated by neighboring systems, including those of agriculturalists. It is therefore intriguing that two regions of the world in which a particularly strong hunting-gathering focus exists - Australia, which has no native agriculture, and South America (particularly the Amazon basin), where most groups typically practice some mix of hunting, gathering, and agriculture - both exhibit a broad regional tendency toward restricted numeral systems, and that in South America this tendency is particularly prevalent among the more "pure" hunter-gatherers (as is also true for Africa). It is likewise intriguing that it is Australia, where virtually no contact with agriculturalist languages took place before European arrival, where restricted numeral systems 
are practically universal. We therefore emphasize the possibility that, despite the enormous variation among numerals in contemporary hunter-gatherer languages, such restricted systems were much more common throughout most of human history.

In conclusion, the richness of numeral systems around the globe, and their relationship to human experience and cognition, can only be understood if we consider a full range of languages, spoken in diverse parts of the world and by peoples that have often been overlooked by science.

Received: 13 September 2011

Revised: 13 December 2011
University of Texas at Austin

Yale University

Grinnell College

University of Arizona

Correspondence addresses: (Epps; corresponding author) Department of Linguistics, University of Texas at Austin, 1 University Station, B5100, Austin, TX 78712 U.S.A.; e-mail: pattieepps@ austin.utexas.edu; (Bowern) Linguistics, Yale University, P.O. Box 208366, New Haven, CT 06520-8366, U.S.A.; e-mail: claire.bowern@yale.edu; (Hansen) Grinnell College. P.O. Box 805, Grinnell, IA 50112, U.S.A.; e-mail: hansency@grinnell.edu; (Hill) School of Anthropology, University of Arizona, P.O. Box 210030, Tucson, AZ 85721-0030, U.S.A.; e-mail: jhill@email.arizona.edu; (Zentz) Linguistics, Yale University, P.O. Box 208366, New Haven, CT 06520-8366, U.S.A.; e-mail: jason.zentz@yale.edu.

Acknowledgements: We thank three anonymous reviewers for their detailed comments on this article, and the audiences of LSA 2011 for useful feedback on portions of this work. All errors remain our own. This work was funded by National Science Foundation grant HSD-0902114, "Dynamics of Hunter-Gatherer Language Change". The surveys of numeral data were conducted by the following people: Australia: Jason Zentz and Claire Bowern; Africa: Jason Zentz; California/Great Basin: Jane H. Hill; South America: Cynthia A. Hansen and Patience Epps, with assistance from Ana Paula Brandão, Kelsey Neely, Leslie Smith, Emily Buell, and Dhananjay Jagannathan. Bettie Gonzalez contributed to the survey of subsistence foci for the South American groups.

\section{Appendix: Languages and data sources}

For each language in our sample, information is given on its genetic affiliation, the subsistence focus of the speaker community, and the language data sources used. Three subsistence foci are distinguished: HG (hunter-gatherer), AG (agriculturalist), and MX (mixed subsistence). See Section 2 above for discussion of how these categorizations are defined. Information about subsistence focus comes from a variety of ethnographic sources (including Olson 1991 and personal knowledge of the authors for South America; for North America, articles in D'Azavedo (ed.) 1986, Ortiz (ed.) 1986, and Kroeber 1925). The data are 
arranged geographically, starting with Australia, followed by California/Great Basin, South America, Africa, and finally Asia.

Table A-1. Australia

\begin{tabular}{|c|c|c|c|}
\hline Language & Language family & $\begin{array}{l}\text { Subsistence } \\
\text { focus }\end{array}$ & Sources of data \\
\hline Bunuba & Bunuban & HG & Rumsey (2000) \\
\hline Gooniyandi & Bunuban & HG & $\begin{array}{l}\text { McGregor (1988, } \\
\text { 1990, 2004) }\end{array}$ \\
\hline Garrwa & Garrwan & $\mathrm{HG}$ & $\begin{array}{l}\text { Breen (2003), Furby } \\
\text { et al. (no date), Furby } \\
\& \text { Furby (1977, no } \\
\text { date) }\end{array}$ \\
\hline Wanyi & Garrwan & HG & Breen (2003) \\
\hline Kajirrabeng & Jarragan & $\mathrm{HG}$ & $\begin{array}{l}\text { Nekes \& Worms } \\
(2006)\end{array}$ \\
\hline Kija & Jarragan & $\mathrm{HG}$ & Blythe (2001) \\
\hline Miriwoong & Jarragan & $\mathrm{HG}$ & $\begin{array}{l}\text { Kofod (1976), Nekes } \\
\text { \& Worms (2006) }\end{array}$ \\
\hline Jingulu & Mirndi & HG & $\begin{array}{l}\text { Nekes \& Worms } \\
\text { (2006) }\end{array}$ \\
\hline Wambaya & Mirndi & $\mathrm{HG}$ & Nordlinger (1998) \\
\hline Bardi & Nyulnyulan & HG & $\begin{array}{l}\text { Bowern } \\
\text { (forthcoming) }\end{array}$ \\
\hline Jabirr-Jabirr & Nyulnyulan & $\mathrm{HG}$ & $\begin{array}{l}\text { Nekes \& Worms } \\
(2006)\end{array}$ \\
\hline Jawi & Nyulnyulan & $\mathrm{HG}$ & $\begin{array}{l}\text { Nekes \& Worms } \\
\text { (2006) }\end{array}$ \\
\hline Ngumbarl & Nyulnyulan & $\mathrm{HG}$ & $\begin{array}{l}\text { Nekes \& Worms } \\
(2006)\end{array}$ \\
\hline Nimanburru & Nyulnyulan & HG & $\begin{array}{l}\text { Nekes \& Worms } \\
\text { (2006) }\end{array}$ \\
\hline Nyikina & Nyulnyulan & $\mathrm{HG}$ & $\begin{array}{l}\text { McGregor (2004), } \\
\text { Nekes \& Worms } \\
(2006)\end{array}$ \\
\hline Nyulnyul & Nyulnyulan & $\mathrm{HG}$ & $\begin{array}{l}\text { Nekes \& Worms } \\
(2006)\end{array}$ \\
\hline Warrwa & Nyulnyulan & $\mathrm{HG}$ & McGregor (2004) \\
\hline Yawuru & Nyulnyulan & $\mathrm{HG}$ & $\begin{array}{l}\text { Nekes \& Worms } \\
\text { (2006) }\end{array}$ \\
\hline
\end{tabular}


Australia (cont.)

\begin{tabular}{|c|c|c|c|}
\hline Language & Language family & $\begin{array}{l}\text { Subsistence } \\
\text { focus }\end{array}$ & Sources of data \\
\hline Adnyamathanha & Pama-Nyungan & $\mathrm{HG}$ & $\begin{array}{l}\text { McEntee \& } \\
\text { McKenzie (1992), } \\
\text { O'Grady (no date), } \\
\text { O'Grady \& Klokeid } \\
\text { (1969), Sommer } \\
\text { (1967) }\end{array}$ \\
\hline $\begin{array}{l}\text { Adnyamathanha } \\
\text { (Wonoka) }\end{array}$ & Pama-Nyungan & $\mathrm{HG}$ & W. Green (1886b) \\
\hline Arabana & Pama-Nyungan & $\mathrm{HG}$ & Hercus (1994) \\
\hline $\begin{array}{l}\text { Arabana (Peake } \\
\text { Telegraph Station) }\end{array}$ & Pama-Nyungan & $\mathrm{HG}$ & Todd (1886) \\
\hline $\begin{array}{l}\text { Arabana (Strangway } \\
\text { Springs) }\end{array}$ & Pama-Nyungan & $\mathrm{HG}$ & Warren (1886) \\
\hline $\begin{array}{l}\text { Arabana } \\
\text { (Wangkatyaka) }\end{array}$ & Pama-Nyungan & $\mathrm{HG}$ & Jacobs (1886c) \\
\hline $\begin{array}{l}\text { Arabana (West of Lake } \\
\text { Eyre) }\end{array}$ & Pama-Nyungan & $\mathrm{HG}$ & $\begin{array}{l}\text { Warren \& Hogarth } \\
\text { (1886) }\end{array}$ \\
\hline $\begin{array}{l}\text { Arabana- } \\
\text { Wangkangurru } \\
\text { (Arabana) }\end{array}$ & Pama-Nyungan & $\mathrm{HG}$ & $\begin{array}{l}\text { Hercus (1989), } \\
\text { Reuther (1973) }\end{array}$ \\
\hline Birlinarra & Pama-Nyungan & HG & $\begin{array}{l}\text { Nordlinger \& Jones } \\
\text { (no date) }\end{array}$ \\
\hline Bularnu & Pama-Nyungan & $\mathrm{HG}$ & Breen (1988) \\
\hline Deniliquin & Pama-Nyungan & $\mathrm{HG}$ & G. Gordon (1886) \\
\hline Dhangu & Pama-Nyungan & $\mathrm{HG}$ & Schebeck (1973) \\
\hline Dhuwal (Djapu) & Pama-Nyungan & $\mathrm{HG}$ & Morphy (1983) \\
\hline $\begin{array}{l}\text { Dhuwala } \\
\text { (Gupapuyngu) }\end{array}$ & Pama-Nyungan & $\mathrm{HG}$ & $\begin{array}{l}\text { Lowe (1996), Zorc } \\
\text { (1986) }\end{array}$ \\
\hline Diyari & Pama-Nyungan & $\mathrm{HG}$ & $\begin{array}{l}\text { Austin (1981), } \\
\text { Howitt (1886), } \\
\text { Reuther (1973) }\end{array}$ \\
\hline Djinay & Pama-Nyungan & $\mathrm{HG}$ & Waters (1988) \\
\hline Gamilaraay & Pama-Nyungan & $\mathrm{HG}$ & $\begin{array}{l}\text { Ash et al. (2003), } \\
\text { Austin (1992), Nekes } \\
\text { \& Worms (2006) }\end{array}$ \\
\hline Gamilaraay (Barraba) & Pama-Nyungan & $\mathrm{HG}$ & $\begin{array}{l}\text { Bench of Magistrates } \\
\text { at Barraba (1886) }\end{array}$ \\
\hline Gamilaraay (Bogabrie) & Pama-Nyungan & HG & $\begin{array}{l}\text { Bench of Magistrates } \\
\text { at Bogabrie (1886) }\end{array}$ \\
\hline $\begin{array}{l}\text { Gamilaraay (Kamilaroi } \\
\text { Station) }\end{array}$ & Pama-Nyungan & HG & Curr (1886) \\
\hline
\end{tabular}


Australia (cont.)

\begin{tabular}{|c|c|c|c|}
\hline Language & Language family & $\begin{array}{l}\text { Subsistence } \\
\text { focus }\end{array}$ & Sources of data \\
\hline $\begin{array}{l}\text { Gamilaraay } \\
\text { (Kamilaroi) }\end{array}$ & Pama-Nyungan & HG & $\begin{array}{l}\text { Mathews (1903), } \\
\text { Ridley (1875) }\end{array}$ \\
\hline Gamilaraay (Moree) & Pama-Nyungan & HG & $\begin{array}{l}\text { Bench of Magistrates } \\
\text { at Moree (1886) }\end{array}$ \\
\hline Gamilaraay (Namoi) & Pama-Nyungan & HG & $\begin{array}{l}\text { Bench of Magistrates } \\
\text { at Wee-waa (1886) }\end{array}$ \\
\hline Gamilaraay (Nundle) & Pama-Nyungan & HG & $\begin{array}{l}\text { Bench of Magistrates } \\
\text { at Nundle (1886) }\end{array}$ \\
\hline Gurindji & Pama-Nyungan & HG & $\begin{array}{l}\text { Patrick McConvell } \\
\text { (personal commu- } \\
\text { nication); McGregor } \\
\text { (2004), McNair \& } \\
\text { McNair (no date), } \\
\text { McNair et al. (1981) }\end{array}$ \\
\hline $\begin{array}{l}\text { Gurindji (Mallee Cliffs } \\
\text { Station to Wentworth) }\end{array}$ & Pama-Nyungan & HG & McFarlane (1886) \\
\hline Jaru & Pama-Nyungan & HG & $\begin{array}{l}\text { Nekes \& Worms } \\
\text { (2006), Tsunoda \& } \\
\text { Hudson (1981) }\end{array}$ \\
\hline Jiwaliny & Pama-Nyungan & HG & Hale (1982) \\
\hline Karajarri & Pama-Nyungan & $\mathrm{HG}$ & $\begin{array}{l}\text { Laves (1929-1932), } \\
\text { McKelson (1989), } \\
\text { Nekes \& Worms } \\
(2006)\end{array}$ \\
\hline Kaurna & Pama-Nyungan & HG & $\begin{array}{l}\text { Amery \& Simpson } \\
\text { (1994); Nekes \& } \\
\text { Worms (2006); } \\
\text { Teichelmann \& } \\
\text { Schürmann (1840, } \\
\text { 1967); Teichelmann, } \\
\text { Schürmann \& Wyatt } \\
\text { (1886) }\end{array}$ \\
\hline Kaurna (Simpson) & Pama-Nyungan & HG & $\begin{array}{l}\text { Teichelmann, } \\
\text { Schürmann \& } \\
\text { Simpson (1990) }\end{array}$ \\
\hline Kukatja & Pama-Nyungan & HG & $\begin{array}{l}\text { Nekes \& Worms } \\
\text { (2006), Peile (1990), } \\
\text { (1993) }\end{array}$ \\
\hline Kungkari & Pama-Nyungan & HG & $\begin{array}{l}\text { Breen (1990), } \\
\text { Holmer (1988), } \\
\text { Tindale } 1940\end{array}$ \\
\hline
\end{tabular}


Australia (cont.)

\begin{tabular}{|c|c|c|c|}
\hline Language & Language family & $\begin{array}{l}\text { Subsistence } \\
\text { focus }\end{array}$ & Sources of data \\
\hline Kuyani & Pama-Nyungan & $\mathrm{HG}$ & $\begin{array}{l}\text { Kingsmill (1886), } \\
\text { O’Grady \& Klokeid } \\
\text { (1969) }\end{array}$ \\
\hline $\begin{array}{l}\text { Kuyani (Eastern Shore } \\
\text { of Lake Torrens) }\end{array}$ & Pama-Nyungan & $\mathrm{HG}$ & W. Green (1886a) \\
\hline Malngin & Pama-Nyungan & $\mathrm{HG}$ & McConvell (1981) \\
\hline Mangarla & Pama-Nyungan & $\mathrm{HG}$ & $\begin{array}{l}\text { McKelson (1988), } \\
\text { Nekes \& Worms } \\
(2006)\end{array}$ \\
\hline Northern Mangarla & Pama-Nyungan & $\mathrm{HG}$ & O’Grady (1967a) \\
\hline Martu Wangka & Pama-Nyungan & $\mathrm{HG}$ & Marsh (1992) \\
\hline Mithaka & Pama-Nyungan & $\mathrm{HG}$ & $\begin{array}{l}\text { Austin (1991), Breen } \\
\text { (1968, fieldnotes) }\end{array}$ \\
\hline Mudburra & Pama-Nyungan & $\mathrm{HG}$ & $\begin{array}{l}\text { Breen (1991), R. } \\
\text { Green (no date), } \\
\text { Patrick McConvell } \\
\text { (personal communi- } \\
\text { cation), McConvell } \\
\text { \& Nash (1984) }\end{array}$ \\
\hline Mulyara & Pama-Nyungan & $\mathrm{HG}$ & Gifford (1886) \\
\hline Muruwari & Pama-Nyungan & $\mathrm{HG}$ & $\begin{array}{l}\text { Nekes \& Worms } \\
(2006), \text { Oates (no } \\
\text { date } a, b)\end{array}$ \\
\hline Narangga & Pama-Nyungan & HG & $\begin{array}{l}\text { Black (1920), } \\
\text { Narungga Aboriginal } \\
\text { Progress Association } \\
(2006)\end{array}$ \\
\hline $\begin{array}{l}\text { Narangga (Yorke's } \\
\text { Peninsula) }\end{array}$ & Pama-Nyungan & $\mathrm{HG}$ & Kühn (1886) \\
\hline $\begin{array}{l}\text { Ngaanyatjarra/ } \\
\text { Ngaatjatjarra }\end{array}$ & Pama-Nyungan & $\mathrm{HG}$ & $\begin{array}{l}\text { Glass (1988), Glass } \\
\& \text { Hackett (2003) }\end{array}$ \\
\hline Ngamini & Pama-Nyungan & $\mathrm{HG}$ & $\begin{array}{l}\text { Breen (1967), } \\
\text { Reuther (1973) }\end{array}$ \\
\hline $\begin{array}{l}\text { Ngamini } \\
\text { (Kopperamana) }\end{array}$ & Pama-Nyungan & $\mathrm{HG}$ & Jacobs (1886a) \\
\hline Ngarinyman & Pama-Nyungan & $\mathrm{HG}$ & Jones (2005) \\
\hline Ngiyampaa & Pama-Nyungan & $\mathrm{HG}$ & $\begin{array}{l}\text { Honery (1877-1878), } \\
\text { Mathews (1902) }\end{array}$ \\
\hline Ngulupulu & Pama-Nyungan & HG & $\begin{array}{l}\text { Machattie \& Little } \\
\text { (1886) }\end{array}$ \\
\hline Nhirrpi & Pama-Nyungan & $\mathrm{HG}$ & Bowern (1999) \\
\hline
\end{tabular}


Australia (cont.)

\begin{tabular}{|c|c|c|c|}
\hline Language & Language family & $\begin{array}{l}\text { Subsistence } \\
\text { focus }\end{array}$ & Sources of data \\
\hline Nukunu & Pama-Nyungan & HG & $\begin{array}{l}\text { Hercus (1992), } \\
\text { Valentine (1886) }\end{array}$ \\
\hline Nyangumarta & Pama-Nyungan & HG & $\begin{array}{l}\text { Geytenbeek \& } \\
\text { Geytenbeek (1991), } \\
\text { Strelley School \& } \\
\text { PALC (no date), B. } \\
\text { Thomas et al. (1990) }\end{array}$ \\
\hline Parnkala & Pama-Nyungan & HG & $\begin{array}{l}\text { Le Souef \& Holden } \\
\text { (1886), Nekes \& } \\
\text { Worms (2006), } \\
\text { Schürmann (1844, } \\
\text { 1967) }\end{array}$ \\
\hline $\begin{array}{l}\text { Parnkala (Gawler } \\
\text { Range) }\end{array}$ & Pama-Nyungan & HG & Sawers (1886) \\
\hline Pirriya & Pama-Nyungan & HG & $\begin{array}{l}\text { Breen (1990), } \\
\text { Tindale (1940) }\end{array}$ \\
\hline $\begin{array}{l}\text { Pitjantjatjara/ } \\
\text { Yankunytjatjara }\end{array}$ & Pama-Nyungan & HG & $\begin{array}{l}\text { Goddard (1987, } \\
\text { 1992, 1996), J. Green } \\
(2003)\end{array}$ \\
\hline Pitta-Pitta & Pama-Nyungan & HG & $\begin{array}{l}\text { Austin (1990), Blair } \\
\text { (1886), Blake (1979) }\end{array}$ \\
\hline Punthamara & Pama-Nyungan & HG & Holmer (1988) \\
\hline Ringu Ringu & Pama-Nyungan & HG & $\begin{array}{l}\text { Craigie (1886), } \\
\text { McLean (1886) }\end{array}$ \\
\hline Ritharrngu & Pama-Nyungan & HG & Heath (1980) \\
\hline Wakaya & Pama-Nyungan & HG & $\begin{array}{l}\text { Breen (1981a, b, } \\
\text { 1985-1986) }\end{array}$ \\
\hline Walmajarri & Pama-Nyungan & HG & $\begin{array}{l}\text { Amery \& Hudson } \\
\text { (1981), J. Green } \\
\text { (2003), Hudson \& } \\
\text { Richards (1981, no } \\
\text { date), Nekes \& } \\
\text { Worms (2006), } \\
\text { Richards \& Hudson } \\
\text { (1990) }\end{array}$ \\
\hline Wangka & Pama-Nyungan & HG & Blythe (2000) \\
\hline Wangkangurru & Pama-Nyungan & HG & Reuther (1973) \\
\hline $\begin{array}{l}\text { Wangkangurru } \\
\text { (Warburton River) }\end{array}$ & Pama-Nyungan & HG & $\begin{array}{l}\text { Cornish (1886b), } \\
\text { Paull (1886) }\end{array}$ \\
\hline Wangkayutyuru & Pama-Nyungan & HG & Blake (no date) \\
\hline Wangkumara & Pama-Nyungan & HG & Robertson (1984) \\
\hline
\end{tabular}


Australia (cont.)

\begin{tabular}{|c|c|c|c|}
\hline Language & Language family & $\begin{array}{l}\text { Subsistence } \\
\text { focus }\end{array}$ & Sources of data \\
\hline $\begin{array}{l}\text { Wangkumara } \\
\text { (Cooper's Creek) }\end{array}$ & Pama-Nyungan & HG & $\begin{array}{l}\text { Sullivan \& Eglinton } \\
\text { (1886) }\end{array}$ \\
\hline Wangkumara (Garlali) & Pama-Nyungan & HG & $\begin{array}{l}\text { McDonald \& Wurm } \\
\text { (1980) }\end{array}$ \\
\hline $\begin{array}{l}\text { Wangkumara } \\
\text { (Nockatoonga) }\end{array}$ & Pama-Nyungan & HG & T. Foott (1886) \\
\hline $\begin{array}{l}\text { Wangkumara } \\
\text { (Thargominda) }\end{array}$ & Pama-Nyungan & HG & Myles (1886) \\
\hline Warlmanpa & Pama-Nyungan & HG & $\begin{array}{l}\text { Nash \& Hale } \\
(1979-1984,1981)\end{array}$ \\
\hline Warlpiri & Pama-Nyungan & HG & $\begin{array}{l}\text { Hale ( } 1967,1995, \\
\text { personal communi- } \\
\text { cation to Barry } \\
\text { Alpher), Swartz } \\
\text { (1996) }\end{array}$ \\
\hline Warluwarra & Pama-Nyungan & HG & Breen (1971, no date) \\
\hline Warnman & Pama-Nyungan & $\mathrm{HG}$ & $\begin{array}{l}\text { Thieberger \& Taylor } \\
\text { (1987), Wangka } \\
\text { Maya et al. (1991) }\end{array}$ \\
\hline Warumungu & Pama-Nyungan & HG & $\begin{array}{l}\text { Disbray (2005), } \\
\text { Simpson (2002), } \\
\text { Simpson \& Heath } \\
(1982)\end{array}$ \\
\hline $\begin{array}{l}\text { Wayilwan (Brewarrina } \\
\text { and Barwan River) }\end{array}$ & Pama-Nyungan & HG & $\begin{array}{l}\text { Bench of Magistrates } \\
\text { at Brewarrina (1886) }\end{array}$ \\
\hline $\begin{array}{l}\text { Wayilwan (Culgoa } \\
\text { River) }\end{array}$ & Pama-Nyungan & HG & J. Foott (1886) \\
\hline Wiradjuri & Pama-Nyungan & HG & $\begin{array}{l}\text { Hosking \& McNicol } \\
\text { (1992) }\end{array}$ \\
\hline Wiradjuri (Carcoar) & Pama-Nyungan & HG & $\begin{array}{l}\text { Bench of Magistrates } \\
\text { at Bathurst (1886a) }\end{array}$ \\
\hline Wiradjuri (Dubbo) & Pama-Nyungan & HG & $\begin{array}{l}\text { Bench of Magistrates } \\
\text { at Dubbo (1886) }\end{array}$ \\
\hline Wiradjuri (Hill End) & Pama-Nyungan & HG & $\begin{array}{l}\text { Bench of Magistrates } \\
\text { at Bathurst (1886b) }\end{array}$ \\
\hline $\begin{array}{l}\text { Wiradjuri (Sources of } \\
\text { Bogan River) }\end{array}$ & Pama-Nyungan & HG & $\begin{array}{l}\text { Bench of Magistrates } \\
\text { at Obley (1886) }\end{array}$ \\
\hline Wiradjuri (Wiradhurri) & Pama-Nyungan & HG & $\begin{array}{l}\text { Larmer (1898), } \\
\text { Schmidt (1919) }\end{array}$ \\
\hline Wirangu & Pama-Nyungan & HG & $\begin{array}{l}\text { Hercus (1999), } \\
\text { O’Grady (1967b) }\end{array}$ \\
\hline
\end{tabular}


Australia (cont.)

\begin{tabular}{|c|c|c|c|}
\hline Language & Language family & $\begin{array}{l}\text { Subsistence } \\
\text { focus }\end{array}$ & Sources of data \\
\hline Wirangu (Streaky Bay) & Pama-Nyungan & HG & $\begin{array}{l}\text { Provis (1886), } \\
\text { Richardson (1886) }\end{array}$ \\
\hline Yan-nhangu & Pama-Nyungan & $\mathrm{HG}$ & Bowern (fieldnotes) \\
\hline Yandruwandha & Pama-Nyungan & HG & $\begin{array}{l}\text { Austin (1991), Breen } \\
\text { (2004), Reuther } \\
\text { (1973) }\end{array}$ \\
\hline $\begin{array}{l}\text { Yandruwandha } \\
\text { (Cooper's Creek) }\end{array}$ & Pama-Nyungan & HG & $\begin{array}{l}\text { Cornish (1886a), } \\
\text { Salmon (1886) }\end{array}$ \\
\hline Yanyuwa & Pama-Nyungan & $\mathrm{HG}$ & Bradley (1992) \\
\hline Yarluyandi & Pama-Nyungan & $\mathrm{HG}$ & $\begin{array}{l}\text { Austin (1991), } \\
\text { Hercus (no date) }\end{array}$ \\
\hline $\begin{array}{l}\text { Yarluyandi (North } \\
\text { Shore of Lake Eyre) }\end{array}$ & Pama-Nyungan & $\mathrm{HG}$ & Jacobs (1886b) \\
\hline Yawarrawarrka & Pama-Nyungan & HG & $\begin{array}{l}\text { Austin (1991), } \\
\text { Reuther (1979) }\end{array}$ \\
\hline Yulparija & Pama-Nyungan & $\mathrm{HG}$ & $\begin{array}{l}\text { McKelson } \\
\text { (1988-1989), } \\
\text { O'Grady (1967c) }\end{array}$ \\
\hline Yuwaalaraay & Pama-Nyungan & HG & $\begin{array}{l}\text { Ash et al. (2003), } \\
\text { Nekes \& Worms } \\
\text { (2006), Williams } \\
(1980)\end{array}$ \\
\hline $\begin{array}{l}\text { Yuwaaliyaay (Balonne, } \\
\text { Nerran) }\end{array}$ & Pama-Nyungan & HG & Hammond (1886) \\
\hline $\begin{array}{l}\text { Yuwaaliyaay } \\
\text { (Yuwaalayaay) }\end{array}$ & Pama-Nyungan & $\mathrm{HG}$ & Ash et al. (2003) \\
\hline Ngarinyin & Wororan & $\mathrm{HG}$ & $\begin{array}{l}\text { McGregor (1992), } \\
\text { McGregor \& Rumsey } \\
\text { (2009) }\end{array}$ \\
\hline Unggumi & Wororan & $\mathrm{HG}$ & $\begin{array}{l}\text { McGregor (1992), } \\
\text { McGregor \& Rumsey } \\
\text { (2009) }\end{array}$ \\
\hline Worrorra & Wororan & HG & $\begin{array}{l}\text { Clendon (2000a, b), } \\
\text { Love (2000), } \\
\text { McGregor (1992), } \\
\text { McGregor \& Rumsey } \\
\text { (2009), Nekes \& } \\
\text { Worms (2006) }\end{array}$ \\
\hline Yawijibaya & Wororan & HG & $\begin{array}{l}\text { McGregor (1992), } \\
\text { McGregor \& Rumsey } \\
\text { (2009) }\end{array}$ \\
\hline
\end{tabular}


Australia (cont.)

\begin{tabular}{llll}
\hline Language & Language family & $\begin{array}{l}\text { Subsistence } \\
\text { focus }\end{array}$ & Sources of data \\
\hline Wardaman & Yangmanic & HG & $\begin{array}{l}\text { Merlan (1994), } \\
\text { Morphy (1983) }\end{array}$ \\
\hline
\end{tabular}

Table A-2. California/Great Basin

\begin{tabular}{|c|c|c|c|}
\hline Language & Language family & $\begin{array}{l}\text { Subsistence } \\
\text { focus }\end{array}$ & Sources of data \\
\hline Wintu & "Penutian" & HG & Pitkin (1985) \\
\hline $\begin{array}{l}\text { Chumash Obispeño } \\
1832\end{array}$ & Chumashan & HG & $\begin{array}{l}\text { Beeler (1964: 12), } \\
\text { Klar (1980) }\end{array}$ \\
\hline $\begin{array}{l}\text { Chumash Barbareño } \\
1832\end{array}$ & Chumashan & HG & $\begin{array}{l}\text { Beeler (1964: 12), } \\
\text { Dixon \& Kroeber } \\
\text { (1907: 682) }\end{array}$ \\
\hline Chumash Ventureño & Chumashan & HG & Beeler (1964: 15-16) \\
\hline Chumash Ineseño & Chumashan & HG & Kroeber (1910: 267) \\
\hline Chumash Isleño & Chumashan & HG & $\begin{array}{l}\text { Dixon \& Kroeber } \\
\text { (1907: 682) }\end{array}$ \\
\hline Seri/Comcaac & Isolate & HG & $\begin{array}{l}\text { Moser \& Marlett } \\
(1997,2005)\end{array}$ \\
\hline Esselen & Isolate & HG & $\begin{array}{l}\text { Shaul (1995), Dixon } \\
\text { \& Kroeber (1907: } \\
683 \text { ) }\end{array}$ \\
\hline Zuni & Isolate & & Newman (1958) \\
\hline Salinan Antoniaño & Isolate & HG & $\begin{array}{l}\text { Turner (1987: 174), } \\
\text { Mason (1918) }\end{array}$ \\
\hline Washo & Isolate & HG & $\begin{array}{l}\text { The Washo Project } \\
\text { (http://washo. } \\
\text { uchicago.edu/) }\end{array}$ \\
\hline Santa Ana Keres & Keresan (Eastern) & AG & Davis (1964) \\
\hline Acoma Keres & Keresan (Western) & AG & W. Miller (1965) \\
\hline Laguna Keres & Keresan (Western) & AG & Lachler (2006) \\
\hline $\begin{array}{l}\text { Tewa (Rio Grande, San } \\
\text { Ildefonso) }\end{array}$ & Kiowa-Tanoan & AG & Harrington (1909) \\
\hline Jemez Towa & Kiowa-Tanoan & AG & Harrington (1909) \\
\hline Northern Tiwa (Piro) & Kiowa-Tanoan & AG & Harrington (1909) \\
\hline Southern Tiwa (Isleta) & Kiowa-Tanoan & AG & Harrington (1909) \\
\hline Northern Tiwa (Taos) & Kiowa-Tanoan & AG & $\begin{array}{l}\text { Harrington (1910), } \\
\text { Trager (1946) }\end{array}$ \\
\hline
\end{tabular}


California/Great Basin (cont.)

\begin{tabular}{|c|c|c|c|}
\hline Language & Language family & $\begin{array}{l}\text { Subsistence } \\
\text { focus }\end{array}$ & Sources of data \\
\hline Gabrielino/Tongva & Uto-Aztecan & HG & $\begin{array}{l}\text { Harrington (notes), } \\
\text { McCawley (1996 for } \\
\text { Merriam notes) }\end{array}$ \\
\hline Southern Ute & Uto-Aztecan & MX & Givón (1980: 34) \\
\hline Tümpisa Shoshone & Uto-Aztecan & HG & Dayley (1989: 161) \\
\hline $\begin{array}{l}\text { Big Smokey Valley } \\
\text { Shoshoni }\end{array}$ & Uto-Aztecan & HG & Crapo (1976: 18) \\
\hline Tohonno O'odham & Uto-Aztecan & AG & $\begin{array}{l}\text { Zepeda (1983), } \\
\text { Saxton et al. (1983) }\end{array}$ \\
\hline Cahuilla & Uto-Aztecan & MX & $\begin{array}{l}\text { Seiler (1977: } \\
\text { 330-335), Seiler \& } \\
\text { Hioki (1979) }\end{array}$ \\
\hline Cupeño & Uto-Aztecan & HG & $\begin{array}{l}\text { Hill \& Nolasquez } \\
\text { (1973), J. Hill (2005) }\end{array}$ \\
\hline Luiseño & Uto-Aztecan & HG & $\begin{array}{l}\text { Kroeber \& Grace } \\
(1960: 118)\end{array}$ \\
\hline Southern Paiute & Uto-Aztecan & MX & Sapir (1930: 262) \\
\hline Northern Paiute & Uto-Aztecan & MX & $\begin{array}{l}\text { Snapp et al. (1982: } \\
\text { 50), Thornes (2003: } \\
211-214 \text { for above } \\
10)\end{array}$ \\
\hline Comanche & Uto-Aztecan & MX & Charney (1993: 160) \\
\hline Western Mono & Uto-Aztecan & HG & $\begin{array}{l}\text { Lamb (1957: } \\
\text { 218-219), Bethel et } \\
\text { al. (eds.) (1993) }\end{array}$ \\
\hline Kawaiisu & Uto-Aztecan & HG & $\begin{array}{l}\text { Zigmond et al. (1991: } \\
65)\end{array}$ \\
\hline Kitanemuk & Uto-Aztecan & HG & Anderton (1988) \\
\hline Hopi & Uto-Aztecan & AG & $\begin{array}{l}\text { Hopi Dictionary } \\
\text { Project (1998) }\end{array}$ \\
\hline Tūbatulabal & Uto-Aztecan & HG & $\begin{array}{l}\text { Voegelin (1935), K. } \\
\text { Hill (2009) }\end{array}$ \\
\hline Serrano & Uto-Aztecan & HG & $\begin{array}{l}\text { Kenneth C. Hill (field } \\
\text { notes) }\end{array}$ \\
\hline Chemehuevi & Uto-Aztecan & AG & Press (1979) \\
\hline Southern Sierra Miwok & Yok-Utian & HG & Broadbent (1964) \\
\hline Northern Sierra Miwok & Yok-Utian & HG & Callaghan (1987) \\
\hline Central Sierra Miwok & Yok-Utian & HG & $\begin{array}{l}\text { Freeland \& } \\
\text { Broadbent (1960) }\end{array}$ \\
\hline Lake Miwok & Yok-Utian & HG & $\begin{array}{l}\text { Callaghan (1958, } \\
\text { 1965) }\end{array}$ \\
\hline
\end{tabular}


California/Great Basin (cont.)

\begin{tabular}{|c|c|c|c|}
\hline Language & Language family & $\begin{array}{l}\text { Subsistence } \\
\text { focus }\end{array}$ & Sources of data \\
\hline Plains Miwok & Yok-Utian & HG & Callaghan (1984) \\
\hline Mutsun & Yok-Utian & HG & $\begin{array}{l}\text { Okrand (1977), } \\
\text { Dixon \& Kroeber } \\
\text { (1907: 683, } \\
\text { Costanoan of San } \\
\text { Juan Bautista) }\end{array}$ \\
\hline Yokuts (Yowlumne) & Yok-Utian & HG & Newman (1944: 55) \\
\hline Yokuts (Yawdanchi) & Yok-Utian & $\mathrm{HG}$ & Kroeber (1963) \\
\hline Yokuts (Palewyami) & Yok-Utian & HG & Kroeber (1963) \\
\hline Nisenan & Yok-Utian & HG & $\begin{array}{l}\text { Uldall \& Shipley } \\
\text { (1966) }\end{array}$ \\
\hline Maidu & Yok-Utian & HG & Shipley (1963) \\
\hline Wappo & Yukian & HG & Sawyer (1965) \\
\hline Yuki & Yukian & $\mathrm{HG}$ & $\begin{array}{l}\text { Sawyer \& Schlichter } \\
\text { (1984), Dixon \& } \\
\text { Kroeber (1907 }\end{array}$ \\
\hline Mojave A & Yuman & AG & $\begin{array}{l}\text { Langdon \& Munro } \\
\text { (1980: 124), Munro } \\
\text { et al. (1993) }\end{array}$ \\
\hline Mojave C & Yuman & AG & $\begin{array}{l}\text { Langdon \& Munro } \\
\text { (1980: 124), Munro } \\
\text { et al. (1993) }\end{array}$ \\
\hline Yavapai & Yuman & AG & $\begin{array}{l}\text { Kendall (1977), } \\
\text { Langdon \& Munro } \\
\text { (1980: 124) }\end{array}$ \\
\hline Kiliwa & Yuman & $\mathrm{HG}$ & $\begin{array}{l}\text { Langdon \& Munro } \\
\text { (1980: 124), Mixco } \\
\text { (1985) }\end{array}$ \\
\hline Cocopa & Yuman & AG & $\begin{array}{l}\text { Langdon \& Munro } \\
\text { (1980: 124), } \\
\text { Crawford (1989) }\end{array}$ \\
\hline
\end{tabular}

Table A-3. South America

\begin{tabular}{llll}
\hline Language & Language family & $\begin{array}{l}\text { Subsistence } \\
\text { focus }\end{array}$ & Sources of data \\
\hline Yuma & Yuman & AG & $\begin{array}{l}\text { Langdon \& Munro } \\
(1980: 124)\end{array}$ \\
\hline
\end{tabular}


South America (cont.)

\begin{tabular}{|c|c|c|c|}
\hline Language & Language family & $\begin{array}{l}\text { Subsistence } \\
\text { focus }\end{array}$ & Sources of data \\
\hline Iipay Aa & Yuman & $\mathrm{HG}$ & $\begin{array}{l}\text { Langdon \& Munro } \\
\text { (1980: 124), Couro \& } \\
\text { Langdon (1975), } \\
\text { Couro \& Hutcheson } \\
\text { (1973) }\end{array}$ \\
\hline Kulina & Arawá & $\mathrm{AG}$ & $\begin{array}{l}\text { D. Green (1997: 4), } \\
\text { Dixon (2004a) }\end{array}$ \\
\hline Wapishana & Arawak & $\mathrm{AG}$ & $\begin{array}{l}\text { Chan (1998-2001, } \\
\text { from Daws \& Hicks), } \\
\text { Santos (2006: 118) }\end{array}$ \\
\hline Yucuna & Arawak & $\mathrm{AG}$ & Schauer (ed.) (2005) \\
\hline Bare & Arawak & $\mathrm{AG}$ & Aikhenvald (1995) \\
\hline Baniwa & Arawak & $\mathrm{AG}$ & $\begin{array}{l}\text { Ramirez (2001), } \\
\text { Huber \& Reed (1992) }\end{array}$ \\
\hline Resígaro & Arawak & $\mathrm{AG}$ & Allin (1979) \\
\hline Tariana & Arawak & AG & $\begin{array}{l}\text { Aikhenvald (2003: } \\
\text { 217-219) }\end{array}$ \\
\hline Paresi & Arawak & $\mathrm{AG}$ & $\begin{array}{l}\text { Ana Paula Brandão } \\
\text { (field notes) }\end{array}$ \\
\hline Warekena & Arawak & $\mathrm{AG}$ & $\begin{array}{l}\text { Aikhenvald (1998: } \\
\text { 298-299, 312-313) }\end{array}$ \\
\hline Baure & Arawak & $\mathrm{AG}$ & Danielsen (2007) \\
\hline Ignaciano & Arawak & $\mathrm{AG}$ & $\begin{array}{l}\text { Chan (1998-2011, } \\
\text { from Ott) }\end{array}$ \\
\hline Kampa & Arawak & $\mathrm{AG}$ & D. Green (1994) \\
\hline Terena & Arawak & $\mathrm{AG}$ & $\begin{array}{l}\text { Ekdahl \& Butler } \\
\text { (1969) }\end{array}$ \\
\hline Matsiguenga & Arawak & $\mathrm{AG}$ & Snell (ed.) (1998) \\
\hline Cabiyarí & Arawak & $\mathrm{AG}$ & Huber \& Reed (1992) \\
\hline Apurinã & Arawak & $\mathrm{AG}$ & Facundes (2000: 359) \\
\hline Kurripaco & Arawak & $\mathrm{AG}$ & Valadares (1994) \\
\hline Piapoco & Arawak & AG & $\begin{array}{l}\text { Klumpp (1995), } \\
\text { Huber \& Reed (1992) }\end{array}$ \\
\hline Wayuu/Guajiro & Arawak & AG & $\begin{array}{l}\text { Captain \& Captain } \\
(2005)\end{array}$ \\
\hline Chamikuro & Arawak & $\mathrm{AG}$ & Parker (ed.) (1995) \\
\hline Piro & Arawak & $\mathrm{AG}$ & Matteson (1965: 107) \\
\hline Palikúr & Arawak & AG & $\begin{array}{l}\text { D. Green (1994, } \\
1997)\end{array}$ \\
\hline Arawak/Lokono & Arawak & $\mathrm{AG}$ & $\begin{array}{l}\text { Bennett (1994), Pet } \\
(1987: 87-88)\end{array}$ \\
\hline
\end{tabular}


South America (cont.)

\begin{tabular}{|c|c|c|c|}
\hline Language & Language family & $\begin{array}{l}\text { Subsistence } \\
\text { focus }\end{array}$ & Sources of data \\
\hline Achagua & Arawak & $\mathrm{AG}$ & $\begin{array}{l}\text { Huber \& Reed } \\
\text { (1992), Meléndez } \\
(1998: 83-90)\end{array}$ \\
\hline Amuesha & Arawak & $\mathrm{AG}$ & $\begin{array}{l}\text { Chan (1998-2011, } \\
\text { from Daigneault) }\end{array}$ \\
\hline Asheninca & Arawak & MX & Mihas (2010) \\
\hline Waurá & Arawak & MX & $\begin{array}{l}\text { Chan (1998-2011, } \\
\text { from Richards) }\end{array}$ \\
\hline Iñapari & Arawak & $\mathrm{HG}$ & Parker (ed.) (1995) \\
\hline Southern Aymara & Aymara & $\mathrm{AG}$ & Pilares (2005) \\
\hline Central Aymara & Aymara & $\mathrm{AG}$ & Pilares (2005) \\
\hline Awa & Barbacoa & $\mathrm{AG}$ & $\begin{array}{l}\text { Huber \& Reed } \\
\text { (1992), Curnow } \\
\text { (1997) }\end{array}$ \\
\hline Tsafiqui pila & Barbacoa & $\mathrm{AG}$ & Huber \& Reed (1992) \\
\hline Totoró & Barbacoa & $\mathrm{AG}$ & Huber \& Reed (1992) \\
\hline Guambiano & Barbacoa & AG & Huber \& Reed (1992) \\
\hline Cha'palaachi & Barbacoa & MX & Huber \& Reed (1992) \\
\hline Bora & Bora & MX & $\begin{array}{l}\text { Aschmann (1993: } \\
\text { 142-143), Thiesen \& } \\
\text { Thiesen (1998) }\end{array}$ \\
\hline Miraña & Bora & MX & $\begin{array}{l}\text { Seifart (2005: } \\
130-132)\end{array}$ \\
\hline Muinane & Bora & MX & $\begin{array}{l}\text { Aschmann (1993: } \\
\text { 142-143) }\end{array}$ \\
\hline Ikpeng & Carib & $\mathrm{AG}$ & $\begin{array}{l}\text { Scandiuzzi (2008: } \\
80-87)\end{array}$ \\
\hline Hixkaryana & Carib & $\mathrm{AG}$ & Derbyshire (1979) \\
\hline Bakairí & Carib & $\mathrm{AG}$ & D. Green (1997: 6) \\
\hline Makuxi & Carib & $\mathrm{AG}$ & Abbott (1991) \\
\hline Kalapalo & Carib & $\mathrm{AG}$ & $\begin{array}{l}\text { Scandiuzzi (2008: } \\
80-86)\end{array}$ \\
\hline Kuikuro & Carib & $\mathrm{AG}$ & $\begin{array}{l}\text { Scandiuzzi (2008: } \\
80-85)\end{array}$ \\
\hline Akawaio & Carib & $\mathrm{AG}$ & $\begin{array}{l}\text { Chan (1998-2011, } \\
\text { from Stegeman) }\end{array}$ \\
\hline Galibi & Carib & $\mathrm{AG}$ & $\begin{array}{l}\text { Chan (1998-2001, } \\
\text { from Ziel) }\end{array}$ \\
\hline Apalai & Carib & $\mathrm{AG}$ & $\begin{array}{l}\text { Koehn \& Koehn } \\
\text { (1995) }\end{array}$ \\
\hline
\end{tabular}


South America (cont.)

\begin{tabular}{|c|c|c|c|}
\hline Language & Language family & $\begin{array}{l}\text { Subsistence } \\
\text { focus }\end{array}$ & Sources of data \\
\hline Waiwai & Carib & MX & $\begin{array}{l}\text { Chan (1998-2011, } \\
\text { from Hemmauer) }\end{array}$ \\
\hline Trió & Carib & MX & $\begin{array}{l}\text { Chan (1998-2011, } \\
\text { from Wilner) }\end{array}$ \\
\hline Carijona & Carib & MX & Huber \& Reed (1992) \\
\hline Waimiri-Atroari & Carib & MX & D. Green (1997: 6-7) \\
\hline Arára & Carib & MX & $\begin{array}{l}\text { D. Green (1997: } \\
\text { 6-8), Costa de Souza } \\
(1995: 2-3)\end{array}$ \\
\hline Yukpa & Carib & MX & Huber \& Reed (1992) \\
\hline Dimina & Chibcha & $\mathrm{AG}$ & Huber \& Reed (1992) \\
\hline Ika & Chibcha & $\mathrm{AG}$ & Huber \& Reed (1992) \\
\hline Kogui & Chibcha & $\mathrm{AG}$ & Huber \& Reed (1992) \\
\hline Barí & Chibcha & MX & Huber \& Reed (1992) \\
\hline Chimila & Chibcha & MX & Huber \& Reed (1992) \\
\hline Tunebo & Chibcha & MX & Huber \& Reed (1992) \\
\hline Wounaan & Chocó & AG & Huber \& Reed (1992) \\
\hline Basurudó & Chocó & MX & Huber \& Reed (1992) \\
\hline Catío & Chocó & MX & Huber \& Reed (1992) \\
\hline Darién & Chocó & MX & Huber \& Reed (1992) \\
\hline Saija & Chocó & MX & Huber \& Reed (1992) \\
\hline Tadó & Chocó & MX & Huber \& Reed (1992) \\
\hline Chamí & Chocó & MX & Huber \& Reed (1992) \\
\hline Guayabero & Guahibo & MX & Huber \& Reed (1992) \\
\hline Cuiba & Guahibo & $\mathrm{HG}$ & Huber \& Reed (1992) \\
\hline Jitnu & Guahibo & HG & Huber \& Reed (1992) \\
\hline Playero & Guahibo & HG & Huber \& Reed (1992) \\
\hline Guahibo & Guahibo & $\mathrm{HG}$ & Huber \& Reed (1992) \\
\hline Kadiwéu & Guaikurú & $\mathrm{AG}$ & $\begin{array}{l}\text { D. Green (1997: 3, } \\
\text { 11) }\end{array}$ \\
\hline Trumai & Isolate & AG & $\begin{array}{l}\text { Guirardello (1999: } \\
\text { 47) }\end{array}$ \\
\hline Movima & Isolate & AG & Haude (2006) \\
\hline Ticuna & Isolate & AG & Anderson (1962) \\
\hline Páez & Isolate & AG & Huber \& Reed (1992) \\
\hline Camsá & Isolate & $\mathrm{AG}$ & Huber \& Reed (1992) \\
\hline Warao & Isolate & AG & $\begin{array}{l}\text { Chan (1998-2011, } \\
\text { from Romero- } \\
\text { Figoeira) }\end{array}$ \\
\hline Urarina & Isolate & MX & Olawsky (2006) \\
\hline
\end{tabular}


South America (cont.)

\begin{tabular}{|c|c|c|c|}
\hline Language & Language family & $\begin{array}{l}\text { Subsistence } \\
\text { focus }\end{array}$ & Sources of data \\
\hline Taushiro & Isolate & MX & $\begin{array}{l}\text { Chan (1998-2011, } \\
\text { from Alicea) }\end{array}$ \\
\hline Andoke & Isolate & MX & Landaburu (1979) \\
\hline Hotï & Isolate & HG & $\begin{array}{l}\text { Marie-Claude Mattei } \\
\text { Müller (word list) }\end{array}$ \\
\hline Yaámana (Yaghan) & Isolate & HG & $\begin{array}{l}\text { Chan (1998-2011, } \\
\text { from Aguilera) }\end{array}$ \\
\hline Huaorani & Isolate & HG & $\begin{array}{l}\text { Chan (1998-2011, } \\
\text { from Peeke) }\end{array}$ \\
\hline Wansõjõt/Puinave & Isolate/Unclassified & AG & $\begin{array}{l}\text { Huber \& Reed } \\
\text { (1992), Chan } \\
\text { (1998-2011, from } \\
\text { Girón) }\end{array}$ \\
\hline Kwaza & Isolate & MX & van der Voort (2006) \\
\hline Kakua & Kakua-Nukak & HG & $\begin{array}{l}\text { Huber \& Reed } \\
\text { (1992), Katherine } \\
\text { Bolaños (field notes) }\end{array}$ \\
\hline Nukak & Kakua-Nukak & HG & Huber \& Reed (1992) \\
\hline Boróro & Macro-Je, Boróro & MX & $\begin{array}{l}\text { D. Green (1997: 5), } \\
\text { Crowell (1979: } \\
\text { 218-219) }\end{array}$ \\
\hline Maxacalí & Macro-Je, Maxacalí & MX & $\begin{array}{l}\text { D. Green (1997: 6), } \\
\text { Popovich \& } \\
\text { Popovich (2005) }\end{array}$ \\
\hline Djeoromitxí & Macro-Je, Jabutí & MX & $\begin{array}{l}\text { Chan (1998-2011, } \\
\text { from van der Voort) }\end{array}$ \\
\hline Guató & Macro-Je, Guató & MX & $\begin{array}{l}\text { Chan (1998-2011, } \\
\text { from Palácio) }\end{array}$ \\
\hline Xavánte & Macro-Je, Je & MX & $\begin{array}{l}\text { D. Green (1997: 5), } \\
\text { McLeod \& Mitchell } \\
\text { (1977) }\end{array}$ \\
\hline Xerénte & Macro-Je, Je & MX & $\begin{array}{l}\text { Melo (2007: 104), D. } \\
\text { Green (1997: 5) }\end{array}$ \\
\hline Suyá/Kisêdjê & Macro-Je, Je & MX & $\begin{array}{l}\text { Chan (1998-2011, } \\
\text { from Nonato) }\end{array}$ \\
\hline Canela & Macro-Je, Je & MX & $\begin{array}{l}\text { D. Green (1997: 3), } \\
\text { Popjes \& Popjes } \\
\text { (1986) }\end{array}$ \\
\hline
\end{tabular}


South America (cont.)

\begin{tabular}{|c|c|c|c|}
\hline Language & Language family & $\begin{array}{l}\text { Subsistence } \\
\text { focus }\end{array}$ & Sources of data \\
\hline Kayapó & Macro-Je, Je & MX & $\begin{array}{l}\text { D. Green (1997: } 5 \text {, } \\
\text { 7); Chan } \\
\text { (1998-2011, from } \\
\text { Thomson) }\end{array}$ \\
\hline Apinayé & Macro-Je, Je & MX & $\begin{array}{l}\text { Chan (1998-2011, } \\
\text { from Ham) }\end{array}$ \\
\hline Karajá & Macro-Je, Karajá & MX & $\begin{array}{l}\text { Chan (1998-2011, } \\
\text { from Rozende and } \\
\text { Fortune) }\end{array}$ \\
\hline Kipeá & Macro-Je, Karirí & MX & Mamiani (1877: 6) \\
\hline Pirahã & Mura & $\mathrm{HG}$ & $\begin{array}{l}\text { Everett (1992: } 353 \text {, } \\
2005)\end{array}$ \\
\hline Dâw & Nadahup & $\mathrm{HG}$ & Martins (2004) \\
\hline Hup & Nadahup & $\mathrm{HG}$ & Epps $(2006,2008)$ \\
\hline Yuhup & Nadahup & $\mathrm{HG}$ & Ospina (2002) \\
\hline Nadëb & Nadahup & $\mathrm{HG}$ & Weir (1984) \\
\hline Sabanê & Nambikwara & MX & $\begin{array}{l}\text { Antunes de Araujo } \\
(2004)\end{array}$ \\
\hline Katukina & Panoan & $\mathrm{AG}$ & $\begin{array}{l}\text { Amarante \& Cândido } \\
(2005: 101,105)\end{array}$ \\
\hline Kapanawa & Panoan & $\mathrm{AG}$ & $\begin{array}{l}\text { Amarante \& Cândido } \\
(2005: 101,105)\end{array}$ \\
\hline Yaminawa & Panoan & $\mathrm{AG}$ & $\begin{array}{l}\text { Faust \& Loos (2002), } \\
\text { Amarante \& Cândido } \\
(2005: 101,105)\end{array}$ \\
\hline Amahuaca & Panoan & $\mathrm{AG}$ & $\begin{array}{l}\text { Hyde (1980), } \\
\text { Amarante \& Cândido } \\
(2005: 101,105)\end{array}$ \\
\hline Matses & Panoan & MX & $\begin{array}{l}\text { Fleck (2003: } \\
559-560)\end{array}$ \\
\hline Matis & Panoan & MX & $\begin{array}{l}\text { Ferreira (2005: } \\
\text { 194-196) }\end{array}$ \\
\hline Shipibo-Conibo & Panoan & MX & Loriot et al. (1993) \\
\hline Kashibo-Kakataibo & Panoan & MX & $\begin{array}{l}\text { Amarante \& Cândido } \\
(2005: 101,105)\end{array}$ \\
\hline Kaxinawa/Cashinahua & Panoan & MX & $\begin{array}{l}\text { Montag (2008), } \\
\text { Amarante \& Cândido } \\
(2005: 101,105)\end{array}$ \\
\hline Sharanawa & Panoan & MX & $\begin{array}{l}\text { Amarante \& Cândido } \\
(2005: 101,105)\end{array}$ \\
\hline
\end{tabular}


South America (cont.)

\begin{tabular}{|c|c|c|c|}
\hline Language & Language family & $\begin{array}{l}\text { Subsistence } \\
\text { focus }\end{array}$ & Sources of data \\
\hline Shanenawa & Panoan & MX & $\begin{array}{l}\text { Cândido (2004: } \\
\text { 139-142) }\end{array}$ \\
\hline Yagua & Peba-Yagua & MX & $\begin{array}{l}\text { Powlison \& Powlison } \\
\text { (1958), Powlison } \\
\text { (1995) }\end{array}$ \\
\hline Incahuasi & Quechua & AG & Pilares (2005) \\
\hline $\begin{array}{l}\text { Imbabura Highland } \\
\text { Quichua }\end{array}$ & Quechua & AG & $\begin{array}{l}\text { Chan (1998-2011, } \\
\text { from Floyd) }\end{array}$ \\
\hline Quechua de Cusco & Quechua & AG & $\begin{array}{l}\text { Chan (1998-2011, } \\
\text { from Phelps) }\end{array}$ \\
\hline Salasaca Quichua & Quechua & AG & Chan (1998-2011) \\
\hline $\begin{array}{l}\text { Southern Pastaza } \\
\text { Quechua }\end{array}$ & Quechua & AG & $\begin{array}{l}\text { Chan (1998-2011, } \\
\text { from Tödter) }\end{array}$ \\
\hline Tena Quichua & Quechua & AG & $\begin{array}{l}\text { Chan (1998-2011, } \\
\text { from Orr) }\end{array}$ \\
\hline Inga & Quechua & AG & Levinsohn (1976) \\
\hline Ancash & Quechua & AG & Pilares (2005) \\
\hline Ayachucho & Quechua & AG & Pilares (2005) \\
\hline Cuzco Collao & Quechua & AG & Pilares (2005) \\
\hline Huallaga & Quechua & AG & Pilares (2005) \\
\hline Junín & Quechua & AG & Pilares (2005) \\
\hline Lamas & Quechua & AG & Pilares (2005) \\
\hline Napo & Quechua & AG & Pilares (2005) \\
\hline Sáliba & Sáliba-Piaroa & MX & Huber \& Reed (1992) \\
\hline Ese Ejja & Tacanan & AG & $\begin{array}{l}\text { Vuillermet (in } \\
\text { preparation) }\end{array}$ \\
\hline Bará/Waimaja & Tukanoan, E. & AG & Huber \& Reed (1992) \\
\hline Barasano & Tukanoan, E. & AG & Huber \& Reed (1992) \\
\hline Karapana (Carapana) & Tukanoan, E. & AG & Huber \& Reed (1992) \\
\hline Tatuyo & Tukanoan, E. & AG & Huber \& Reed (1992) \\
\hline Tukano & Tukanoan, E. & AG & $\begin{array}{l}\text { Huber \& Reed } \\
\text { (1992), Ramirez } \\
\text { (1997) }\end{array}$ \\
\hline Tuyuka & Tukanoan, E. & AG & Huber \& Reed (1992) \\
\hline Yurutí & Tukanoan, E. & AG & Huber \& Reed (1992) \\
\hline Macuna & Tukanoan, E. & AG & Huber \& Reed (1992) \\
\hline Waikhana/Piratapuyo & Tukanoan, E. & AG & Huber \& Reed (1992) \\
\hline Siriano & Tukanoan, E. & AG & Huber \& Reed (1992) \\
\hline Kotiria/Wanano & Tukanoan, E. & AG & $\begin{array}{l}\text { Stenzel (2004: } \\
185-191)\end{array}$ \\
\hline Retuarã/Tanimuca & Tukanoan, E. & $\mathrm{AG}$ & Strom (1992) \\
\hline
\end{tabular}


South America (cont.)

\begin{tabular}{|c|c|c|c|}
\hline Language & Language family & $\begin{array}{l}\text { Subsistence } \\
\text { focus }\end{array}$ & Sources of data \\
\hline Kubeo & Tukanoan, E. & MX & $\begin{array}{l}\text { Morse \& Maxwell } \\
\text { (1999) }\end{array}$ \\
\hline Desano & Tukanoan, E. & MX & $\begin{array}{l}\text { M. Miller (1999: } \\
46-47)\end{array}$ \\
\hline Siona & Tukanoan, W. & AG & Wheeler (1970) \\
\hline Koreguaje & Tukanoan, W. & AG & $\begin{array}{l}\text { Cook \& Gralow } \\
\text { (2001) }\end{array}$ \\
\hline Secoya & Tukanoan, W. & AG & Huber \& Reed (1992) \\
\hline Orejon & Tukanoan, W. & AG & Velie \& Velie (1981) \\
\hline Mundurukú & Tupí & AG & D. Green (1997: 8-9) \\
\hline Kamaiurá & Tupí & $A G$ & Seki (2000) \\
\hline Tapirape & Tupí & AG & $\begin{array}{l}\text { Praça (2007: } \\
\text { 149-151) }\end{array}$ \\
\hline Karo & Tupí & AG & Gabas (1999: 65) \\
\hline Karitiana & Tupí & $A G$ & C. Everett (2006) \\
\hline Aweti & Tupí & AG & $\begin{array}{l}\text { Chan (1998-2011, } \\
\text { from Drude) }\end{array}$ \\
\hline Satereé-Maweé & Tupí & AG & $\begin{array}{l}\text { Chan (1998-2011, } \\
\text { from Pereira da } \\
\text { Silva) }\end{array}$ \\
\hline Gavião & Tupí & MX & Moore (1984) \\
\hline Suruií & Tupí & MX & $\begin{array}{l}\text { Chan (1998-2011, } \\
\text { from Dietrich) }\end{array}$ \\
\hline Asuriní do Xingú & Tupí, Tupí-Guaraní & AG & $\begin{array}{l}\text { Nicholson (1982: } \\
\text { 29-30, 71-72) }\end{array}$ \\
\hline Asuriní do Trocará & Tupí, Tupí-Guaraní & MX & $\begin{array}{l}\text { Nicholson (1982: } \\
\text { 29-30) }\end{array}$ \\
\hline Cocama-Cocamilla & Tupí, Tupí-Guaraní & AG & $\begin{array}{l}\text { Chan (1998-2011, } \\
\text { from Vallejos) }\end{array}$ \\
\hline Guajájara & Tupí, Tupí-Guaraní & AG & $\begin{array}{l}\text { D. Green (1997: 5), } \\
\text { Chan (1998-2011, } \\
\text { from da Silva) }\end{array}$ \\
\hline Tupínambá & Tupí, Tupí-Guaraní & AG & $\begin{array}{l}\text { Lemos Barbosa } \\
\text { (1956) }\end{array}$ \\
\hline Kayabí & Tupí, Tupí-Guaraní & AG & $\begin{array}{l}\text { D. Green (1997: 5), } \\
\text { Chan (1998-2011), } \\
\text { from Dobson and } \\
\text { Dietrich) }\end{array}$ \\
\hline Wayampi & Tupí, Tupí-Guaraní & AG & D. Green (1997: 5) \\
\hline Guaraní & Tupí, Tupí-Guaraní & $A G$ & Dooley (1982) \\
\hline Akewere & Tupí, Tupí-Guaraní & $A G$ & D. Green (1997: 5) \\
\hline
\end{tabular}


South America (cont.)

\begin{tabular}{|c|c|c|c|}
\hline Language & Language family & $\begin{array}{l}\text { Subsistence } \\
\text { focus }\end{array}$ & Sources of data \\
\hline Tembé & Tupí, Tupí-Guaraní & MX & $\begin{array}{l}\text { D. Green (1997: 5), } \\
\text { Chan (1998-2011, } \\
\text { from Dietrich) }\end{array}$ \\
\hline Parakanã & Tupí, Tupí-Guaraní & MX & $\begin{array}{l}\text { Chan (1998-2011, } \\
\text { from Caetana Souza) }\end{array}$ \\
\hline Omagua & Tupí, Tupí-Guaraní & MX & $\begin{array}{l}\text { Lev Michael } \\
\text { (personal commu- } \\
\text { nication) }\end{array}$ \\
\hline Tenharim & Tupí, Tupí-Guaraní & MX & D. Green (1997: 4) \\
\hline Murui Huitoto & Witotoan & MX & $\begin{array}{l}\text { Aschmann (1993: } \\
\text { 142-143), Burtch } \\
(1983)\end{array}$ \\
\hline Minica Huitoto & Witotoan & MX & $\begin{array}{l}\text { Aschmann (1993: } \\
\text { 142-143), Minor \& } \\
\text { Minor (1987) }\end{array}$ \\
\hline Nipode Huitoto & Witotoan & MX & $\begin{array}{l}\text { Aschmann (1993: } \\
\text { 142-143), Minor \& } \\
\text { Minor (1971) }\end{array}$ \\
\hline Ocaina & Witotoan & MX & $\begin{array}{l}\text { Aschmann (1993: } \\
\text { 142-143), Leach } \\
\text { 1969) }\end{array}$ \\
\hline Ninam & Yanomam & HG & $\begin{array}{l}\text { Gomez (1990: } \\
\text { 121-122), Migliazza } \\
(1972)\end{array}$ \\
\hline Sanumá & Yanomam & $\mathrm{HG}$ & $\begin{array}{l}\text { Migliazza (1972), D. } \\
\text { Green (1997: 4), } \\
\text { Borgman (1990: 152) }\end{array}$ \\
\hline Yanomami & Yanomam & HG & $\begin{array}{l}\text { Mattei-Müller \& } \\
\text { Serowèe (2007) }\end{array}$ \\
\hline Yanomamo & Yanomam & $\mathrm{HG}$ & Migliazza (1972) \\
\hline Iquito & Zaparoan & $\mathrm{AG}$ & Hansen (2007) \\
\hline Záparo & Zaparoan & AG & Peeke (1991: 62) \\
\hline Arabela & Zaparoan & MX & Rich (1999) \\
\hline
\end{tabular}

Table A-4. Africa

\begin{tabular}{llll}
\hline Language & Language family & $\begin{array}{l}\text { Subsistence } \\
\text { focus }\end{array}$ & Sources of data \\
\hline Tikar/Bedzan & Bantoid & AG [+HG] & Stanley (1986) \\
Akoose & Bantu A10 & AG & Hedinger (2008) \\
\hline
\end{tabular}


Africa (cont.)

\begin{tabular}{|c|c|c|c|}
\hline Language & Language family & $\begin{array}{l}\text { Subsistence } \\
\text { focus }\end{array}$ & Sources of data \\
\hline Gyele/Kola & Bantu A80 & HG & $\begin{array}{l}\text { Chan (1998-2011, } \\
\text { from Ngue Um) }\end{array}$ \\
\hline Kakı & Bantu A90 & $\mathrm{AG}$ & Ernst (ed.) (1989) \\
\hline Tsogo/Bongo & Bantu B30 & $\mathrm{AG}[+\mathrm{HG}]$ & $\begin{array}{l}\text { Raponda-Walker } \\
\text { (1996) }\end{array}$ \\
\hline Teke/Bongo & Bantu B70 & $\mathrm{AG}[+\mathrm{HG}]$ & Etsio (1999) \\
\hline Bagandou Aka & Bantu C10 & $\mathrm{HG}$ & $\begin{array}{l}\text { Thomas et al. (eds.) } \\
\text { (1981-present) }\end{array}$ \\
\hline Bayanga Aka & Bantu C10 & HG & $\begin{array}{l}\text { Thomas et al. (eds.) } \\
\text { (1981-present) }\end{array}$ \\
\hline Mongoumba Aka & Bantu C10 & HG & $\begin{array}{l}\text { Thomas et al. (eds.) } \\
\text { (1981-present) }\end{array}$ \\
\hline Lingala & Bantu C40 & AG & $\begin{array}{l}\text { Pashi \& Turnbull } \\
\text { (1994) }\end{array}$ \\
\hline Rumanyo (Gciriku) & Bantu K70 & MX & $\begin{array}{l}\text { Möhlig \& Shiyaka- } \\
\text { Mberema (2005) }\end{array}$ \\
\hline Herero & Bantu R30 & $\mathrm{AG}$ & $\begin{array}{l}\text { Viljoen \& } \\
\text { Kamupingene (1983) }\end{array}$ \\
\hline Tswana & Bantu S30 & AG & $\begin{array}{l}\text { Lukusa \& Monaka } \\
\text { (2008) }\end{array}$ \\
\hline Kgalagadi & Bantu S30 & MX & Matumo (1993) \\
\hline Lese/Efe & Central Sudanic & $\mathrm{AG}[+\mathrm{HG}]$ & Vorbichler (1965) \\
\hline Dahalo & Cushitic & $\mathrm{HG}$ & Tosco (1991) \\
\hline Jara Boni & Cushitic & HG & Heine (1982) \\
\hline Kilii Boni & Cushitic & $\mathrm{HG}$ & Heine (1982) \\
\hline Waata & Cushitic & HG & Heine (1981) \\
\hline Sandawe & Isolate & HG & Kagaya (1993) \\
\hline Khoekhoegowab & Khoe & AG & $\begin{array}{l}\text { Haacke \& Eiseb } \\
\text { (2002) }\end{array}$ \\
\hline Kxoe & Khoe & HG & Kilian-Hatz (2003) \\
\hline Naro & Khoe & HG & Visser (2001) \\
\hline |Gui & Khoe & HG & $\begin{array}{l}\text { Tanaka \& Sugawara } \\
\text { (eds.) (2010) }\end{array}$ \\
\hline ॥Gana & Khoe & HG & $\begin{array}{l}\text { Tanaka \& Sugawara } \\
\text { (eds.) (2010) }\end{array}$ \\
\hline Ju|'hoan & Kx'a & HG & Dickens (1994) \\
\hline Northwestern!Xun & $\mathrm{Kx}{ }^{\prime} \mathrm{a}$ & $\mathrm{HG}$ & $\begin{array}{l}\text { König \& Heine } \\
\text { (2008) }\end{array}$ \\
\hline !Xoóoõ & Tuu & HG & Traill (1994) \\
\hline
\end{tabular}


Africa (cont.)

\begin{tabular}{llll}
\hline Language & Language family & $\begin{array}{l}\text { Subsistence } \\
\text { focus }\end{array}$ & Sources of data \\
\hline Gbanziri & Ubangian & AG & $\begin{array}{l}\text { Brisson \& Boursier } \\
(1979), \text { Brisson }\end{array}$ \\
& Ubangian & AG & $\begin{array}{l}\text { Calloc'h (1911) } \\
\text { Monzombo }\end{array}$ \\
$\begin{array}{l}\text { Ngbaka } \\
\text { Baka }\end{array}$ & Ubangian & AG & Calloc'h (1911) \\
\hline
\end{tabular}

Table A-5. Asia

\begin{tabular}{|c|c|c|c|}
\hline Language & Language family & $\begin{array}{l}\text { Subsistence } \\
\text { focus }\end{array}$ & Sources of data \\
\hline Agta (Casiguran & Austronesian & HG & Headland \& \\
\hline Dumagat) & & & Headland (1974: ii) \\
\hline Jahai & Mon-Khmer, Aslian & HG & Burenhult (2005: 87) \\
\hline Semelai & Mon-Khmer, Aslian & HG & Kruspe (2004) \\
\hline Ainu & Isolate & HG & $\begin{array}{l}\text { Hurford (1975: 239, } \\
\text { citing Pott 1847: 86) }\end{array}$ \\
\hline Nivkh & Isolate & HG & $\begin{array}{l}\text { Gruzdeva (1998: } \\
\text { 23-25) }\end{array}$ \\
\hline Ket & Yeniseian & HG & Vajda (2004: 36) \\
\hline Kolyma Yukaghir & Yukaghir & HG & Maslova (2003: 260) \\
\hline
\end{tabular}

\section{References}

Abbott, Miriam. 1991. Macushi. In Desmond C. Derbyshire \& Geoffrey K. Pullum (eds.), Handbook of Amazonian languages, Vol. 3, 23-160. Berlin: Mouton de Gruyter.

Aikhenvald, Alexandra. 1995. Baré. München: Lincom Europa.

Aikhenvald, Alexandra. 1998. Warekena. In Desmond Derbyshire \& Geoffrey Pullum (eds.), Handbook of Amazonian languages, Vol. 4, 225-439. Berlin: Mouton de Gruyter.

Aikhenvald, Alexandra Y. 2002. Language contact in Amazonia. Oxford: Oxford University Press.

Aikhenvald, Alexandra. 2003. A grammar of Tariana, from northwestern Amazonia. Cambridge: Cambridge University Press.

Allin, Trevor R. 1979. Vocabulario resígaro (Documento de Trabajo 16). Yarinacocha, Peru: Instituto Lingüístico de Verano. http://www.sil.org/americas/peru/show_work.asp?id=15286

Amarante Ribeiro, Lincoln Almir \& Gláucia Vieira Cândido. 2005. Uma descrição do sistema numérico da família Pano. MOARA 24. 96-108.

Amery, Rob \& Joyce Hudson. 1981. Walmatjari Billiluna wordlist. In Menning \& Nash (eds.) 1981. Aboriginal Studies Electronic Data Archive (ASEDA) 0142. http://aseda.aiatsis.gov.au Amery, Rob \& Jane Simpson. 1994. Kaurna. In Nick Thieberger \& William McGregor (eds.), Macquarie Aboriginal words: A dictionary of words from Australian Aboriginal and Torres Strait Islander languages, 144-172. Sydney: Macquarie Library. 
Andersen, Henning. 2005. The plasticity of universal grammar. In Willy Østreng (ed.), Convergence: Interdisciplinary communications 2004/2005, 21-26. Oslo: Senter for grunnforskning ved Det Norske Videnskaps-Akademi.

Anderson, Doris G. 1962. Conversational Ticuna. Norman, OK: SIL and University of Oklahoma.

Anderton, Alice. 1988. The language of the Kitanemuks of California. Los Angeles: University of California doctoral dissertation.

Antunes de Araujo, Gabriel. 2004. A grammar of Sabanê, a Nambikwaran language (LOT Dissertation Series 94). Utrecht: LOT.

Aschmann, Richard P. 1993. Proto Witotoan. Dallas: Summer Institute of Linguistics and University of Texas at Arlington.

Ash, Anna, John Giacon \& Amanda Lissarrague. 2003. Gamilaraay, Yuwaalaraay \& Yuwaalayaay dictionary. Alice Springs, Australia: IAD Press.

Austin, Peter. 1981. A grammar of Diyari, South Australia. Cambridge: Cambridge University Press.

Austin, Peter. 1990. Classification of Lake Eyre languages. La Trobe University Working Papers in Linguistics 3. 171-201.

Austin, Peter. 1991. The Karangura language. Records of the South Australian Museum 25(2). 129-137.

Austin, Peter. 1992. A dictionary of Gamilaraay, northern New South Wales. Bundoora, Australia: Department of Linguistics, La Trobe University.

Bahuchet, Serge. 1993. History of the inhabitants of the central African rain forest: Perspectives from comparative linguistics. In Claude M. Hladik, Annette Hladik, Olga F. Linares, Hélène Pagezy, Alison Semple \& Malcolm Hadley (eds.), Tropical forests, people, and food: Biocultural interactions and applications to development (Man and the Biosphere 13), 37-54. Paris: UNESCO.

Bahuchet, Serge (forthcoming). Languages of African rainforest "pygmy" hunter-gatherers: Language shifts without cultural admixture. In Tom Güldemann, Patrick McConvell \& Richard Rhodes (eds.), Hunter-gatherers and linguistic history: A global perspective. Cambridge: Cambridge University Press. Preliminary version at http://hal.archives-ouvertes.fr/ hal-00548207/en/ (accessed 2 September 2011).

Balée, William. 1992. People of the fallow: A historical ecology of foraging in lowland South America. In Kent H. Redford \& Christine Padoch (eds.), Conservation of Neotropical forests: Working from traditional resource use, 35-57. New York: Columbia University Press.

Balée, William. 1999. Modes of production and ethnobotanical vocabulary: A controlled comparison of Guajá and Ka'apor. In Ted L. Gragson \& Ben G. Blount (eds.), Ethnoecology: Knowledge, resources, and rights, 24-40. Athens, GA: University of Georgia Press.

Beeler, Madison S. 1961. Senary counting in California Penutian. Anthropological Linguistics 3. $1-8$.

Beeler, Madison S. 1964. Ventureño numerals. In William Bright (ed.), Studies in Californian linguistics, 13-18. Berkeley, CA: University of California Press.

Beeler, Madison S. 1986. Chumash numerals. In Michael P. Closs (ed.), Native American mathematics, 109-128. Austin: University of Texas Press.

Bench of Magistrates at Barraba. 1886. Barraba. In Curr (ed.) 1886, Vol. 3, 320-321.

Bench of Magistrates at Bathurst. 1886a. Carcoar. In Curr (ed.) 1886, Vol. 3, 384-385.

Bench of Magistrates at Bathurst. 1886b. Hill End. In Curr (ed.) 1886, Vol. 3, 376-377.

Bench of Magistrates at Bogabrie. 1886. Bogabrie. In Curr (ed.) 1886, Vol. 3, 322-323.

Bench of Magistrates at Brewarrina. 1886. Brewarrina and Barwan River - The Wailwun language. In Curr (ed.) 1886, Vol. 3, 330-331.

Bench of Magistrates at Dubbo. 1886. Dubbo. In Curr (ed.) 1886, Vol. 3, 372-373.

Bench of Magistrates at Moree. 1886. Moree. In Curr (ed.) 1886, Vol. 3, 314-315.

Bench of Magistrates at Nundle. 1886. Nundle. In Curr (ed.) 1886, Vol. 3, 316-317.

Bench of Magistrates at Obley. 1886. Sources of Bogan River. In Curr (ed.) 1886, Vol. 3, 382-383. 
Bench of Magistrates at Wee-waa. 1886. Namoi. In Curr (ed.) 1886, Vol. 3, 318-319.

Bennett, John Peter. 1994. An Arawak-English dictionary with an English word-list. Georgetown: Walter Roth Museum of Anthropology, Archaeology and Anthropology.

Bethel, Rosalie, Paul V. Kroskrity, Christopher Loether \& Gregory Reinhardt (compilers \& eds.). 1993. A dictionary of Western Mono. 2nd edn. Corrected, updated, and revised by Christopher Loether \& Rosalie Bethel. Northfork, CA: Northfork Band of the Western Mono.

Black, J. M. 1920. Vocabularies of four South Australian languages, Adelaide, Narrunga, Kukata, and Narrinyeri with special reference to their speech sounds. Transactions of the Royal Society of South Australia 44. 76-93. Aboriginal Studies Electronic Data Archive (ASEDA) 0257. http://aseda.aiatsis.gov.au

Blair, William. 1886. The Hamilton River, Warenda. In Curr (ed.) 1886, Vol. 2, 352-353.

Blake, Barry J. 1979. Pitta-Pitta. In R. M. W. Dixon \& Barry J. Blake (eds.), Handbook of Australian languages, Vol. 1, 182-242. Canberra: Australian National University Press.

Blake, Barry J. (no date). Wangka-Yutjurru wordlist. Manuscript.

Blažek, Václav. 1999. Numerals: Comparative etymological analyses and their implications. Brno: Masarykova Univerzita.

Blench, Roger M. 1999. Are the African Pygmies an ethnographic fiction? In Karen Biesbrouck, Stefan Elders \& Gerda Rossel (eds.), Central African hunter-gatherers in a multidisciplinary perspective: Challenging elusiveness, 41-60. Leiden: Research School for Asian, African and Amerindian Studies (CNWS), Universiteit Leiden.

Blust, Robert. 1976. A third palatal reflex in Polynesian languages. Journal of the Polynesian Society 85. 339-358.

Blythe, J. Noel. 2000. Wangka dictionary and grammar. Manuscript. Aboriginal Studies Electronic Data Archive (ASEDA) 0709. http://aseda.aiatsis.gov.au

Blythe, Joseph. 2001. Yuwurriyangem Kijam (Our language Kija): A phrasebook of the Kija language. Halls Creek, Australia: Kimberley Language Resource Centre.

Borgman, Donald M. 1990. Sanuma. In Desmond C. Derbyshire \& Geoffrey K. Pullum (eds.), Handbook of Amazonian languages, Vol. 2, 15-248. Berlin: Mouton de Gruyter.

Bowern, Claire. 1999. Nhirrpi vocabulary. Manuscript.

Bowern, Claire. 2010. Correlates of language change in hunter-gatherer and other "small" languages. Language and Linguistics Compass 4. 665-679.

Bowern, Claire (forthcoming). A reference grammar of Bardi. Berlin: Mouton de Gruyter.

Bowern, Claire, Patience Epps, Russell Gray, Jane Hill, Keith Hunley, Patrick McConvell \& Jason Zentz. 2011. Does lateral transmission obscure inheritance in hunter-gatherer languages? PLoS One 6(9). e25195. http://www.plosone.org/article/info\%3Adoi\%2F10.1371 $\%$ 2Fjournal.pone.0025195

Bowern, Claire \& Jason Zentz. 2011. Diversity in the numeral systems of Australian languages. Manuscript, Yale University.

Bradley, John. 1992. Yanyuwa Wuka: Language from Yanyuwa country. Manuscript.

Breen, Gavan. 1967. Ngamini material. Manuscript. Australian Institute of Aboriginal and Torres Strait Islander Studies MS 117.

Breen, Gavan. 1968. Mithaka. Manuscript. Australian Institute of Aboriginal and Torres Strait Islander Studies MS 121.

Breen, Gavan. 1971. A description of the Warluwara language. Melbourne: Monash University MA thesis.

Breen, Gavan. 1981a. Wakaya (West) wordlist. In Menning \& Nash (eds.) 1981. Manuscript. Aboriginal Studies Electronic Data Archive (ASEDA) 0140. http://aseda.aiatsis.gov.au

Breen, Gavan. 1981b. Wakaya wordlist. In Menning \& Nash (eds.) 1981. Manuscript. Aboriginal Studies Electronic Data Archive (ASEDA) 0139. http://aseda.aiatsis.gov.au

Breen, Gavan. 1985-1986. Wakaya. Manuscript. Aboriginal Studies Electronic Data Archive (ASEDA) 0047. http://aseda.aiatsis.gov.au 
Breen, Gavan. 1988. Bularnu grammar and vocabulary machine-readable files. Manuscript. Aboriginal Studies Electronic Data Archive (ASEDA) 0007. http://aseda.aiatsis.gov.au

Breen, Gavan. 1990. Salvage studies of a number of extinct Aboriginal languages of western Queensland (Pacific Linguistics B-105). Canberra: Australian National University.

Breen, Gavan. 1991. Mudburra graded wordlist. Manuscript. Aboriginal Studies Electronic Data Archive (ASEDA) 0269. http://aseda.aiatsis.gov.au

Breen, Gavan. 2003. Wanyi and Garrwa comparative data. In Nicholas Evans (ed.), The non-PamaNyungan languages of Northern Australia: Comparative studies of the continent's most linguistically complex region (Pacific Linguistics 552), 425-462. Canberra: Australian National University.

Breen, Gavan. 2004. Innamincka words: Yandruwandha dictionary and stories (Pacific Linguistics 559). Canberra: Australian National University.

Breen, Gavan (no date). Warluwarra wordlist. Manuscript. Aboriginal Studies Electronic Data Archive (ASEDA) 0253. http://aseda.aiatsis.gov.au

Brisson, Robert. 1984. Lexique français-baka. Douala, Cameroon: Brisson.

Brisson, Robert \& Daniel Boursier. 1979. Petit dictionnaire baka-français. Douala, Cameroon: Brisson.

Broadbent, Sylvia. 1964. The Southern Sierra Miwok language. Berkeley, CA: University of California Press.

Burenhult, Niclas. 2005. A grammar of Jahai (Pacific Linguistics 566). Canberra: Australian National University.

Burtch, Shirley A. 1983. Diccionario huitoto murui I-II (Serie Lingüística Peruana 20). 2 vols. Yarinacocha, Peru: Instituto Lingüístico de Verano. http://www.sil.org/americas/peru/show_ work.asp?id=18498

Callaghan, Catherine A. 1958. Note on Lake Miwok numerals. International Journal of American Linguistics 24. 247.

Callaghan, Catherine A. 1965. Lake Miwok dictionary. Berkeley, CA: University of California Press.

Callaghan, Catherine A. 1984. Plains Miwok dictionary. Berkeley, CA: University of California Press.

Callaghan, Catherine A. 1987. Northern Sierra Miwok dictionary. Berkeley, CA: University of California Press.

Calloc'h, J. 1911. Vocabulaire français-gmbwaga-gbanziri-monjombo: Précédé d'éléments de grammaire. Paris: Geuthner.

Cândido, Gláucia Viera. 2004. Descrição morfossintática da língua shanenawa (Pano). Campinas, Brazil: Universidade Estadual de Campinas doctoral dissertation.

Captain, David M. \& Linda B. Captain. 2005. Diccionario básico ilustrado: Wayuunaiki-español, español-wayuunaiki. Bogotá: Editorial Fundación para el Desarollo de los Pueblos Marginados.

Chan, Eugene. 1998-2011. Numeral systems of the world's languages. Database. http://lingweb. eva.mpg.de/numeral/

Charney, Jean Ormsby. 1993. A grammar of Comanche. Lincoln, NE: University of Nebraska Press.

Clendon, Mark. 2000a. A grammar of Worrorra. Halls Creek, Australia: Kimberley Language Resource Centre.

Clendon, Mark. 2000b. A provisional Worrorra dictionary. Halls Creek, Australia: Kimberley Language Resource Centre.

Comrie, Bernard. 1999. Haruai numerals and their implications for the history and typology of numeral systems. In Gvozdanović (ed.) 1999, 81-94.

Comrie, Bernard. 2005. Endangered numeral systems. In Jan Wohlgemuth \& Tyko Dirksmeyer (eds.), Bedrohte Vielfalt: Aspekte des Sprach(en)tods, 203-230. Berlin: Weißensee-Verlag. 
Comrie, Bernard. 2011. Numeral bases. In Matthew S. Dryer \& Martin Haspelmath (eds.), The world atlas of language structures online, Chapter 131. München: Max Planck Digital Library. http://wals.info/chapter/131 (accessed 20 August 2011).

Cook, Dorothy M. \& Frances L. Gralow. 2001. Diccionario bilingüe koreguaje-español, españolkoreguaje. Bogotá: Editorial Alberto Lleras Camargo.

Cornish, W. H. 1886a. Cooper's Creek. In Curr (ed.) 1886, Vol. 2, 28-29.

Cornish, W. H. 1886b. Warburton River. In Curr (ed.) 1886, Vol. 2, 22-23.

Costa de Souza, Isaac. 1995. Etnomatemática arara: Indício de um sistema binário. Brasília: Associação Lingüística Evangélica Missionária and Summer Institute of Linguistics.

Couro, Ted \& Christina Hutcheson. 1973. Dictionary of Mesa Grande Diegueño. Morongo Indian Reservation, Banning, CA: Malki Museum Press.

Couro, Ted \& Margaret Langdon. 1975. Let's talk Iipay 'Aa. Morongo Indian Reservation, Banning, CA: Malki Museum Press.

Craigie, James. 1886. The Lower Georgina River. In Curr (ed.) 1886, Vol. 2, 356-357.

Crapo, Richley H. 1976. Big Smokey Valley Shoshoni (Desert Research Institute Publications in the Social Sciences 10). Reno, NV: Desert Research Institute.

Crawford, James M. 1989. Cocopa dictionary. Berkeley, CA: University of California Press.

Crowell, Thomas Harris. 1979. A grammar of Bororo. Ithaca, NY: Cornell University doctoral dissertation.

Crowley, Terry \& Claire Bowern. 2010. An introduction to historical linguistics. Oxford: Oxford University Press.

Curnow, Timothy Jowan. 1997. A grammar of Awa Pit (Cuaiquer): An indigenous language of south-western Colombia. Canberra: Australian National University doctoral dissertation.

Curr, Montagu. 1886. Kamilaroi Station. In Curr (ed.) 1886, Vol. 2, 318-321.

Curr, Edward M. (ed.). 1886. The Australian race: Its origin, languages, customs, place of landing in Australia, and the routes by which it spread itself over that continent. 4 vols. Melbourne: Ferres.

D’Azavedo, Warren (ed.). 1986. Handbook of North American Indians, Vol. 11: Great Basin. Washington, DC: Smithsonian Institution.

Danielsen, Swintha. 2007. Baure: An Arawak language of Bolivia (Indigenous Languages of Latin America 6). Leiden: CNWS.

Davis, Irvine. 1964. The language of Santa Ana Pueblo (Bureau of American Ethnology, Smithsonian Institution: Anthropological Papers 69). Washington, DC: U.S. Government Printing Office.

Dayley, Jon. 1989. Tümpisa Shoshone (Panamint) dictionary. Berkeley, CA: University of California Press.

Derbyshire, Desmond C. 1979. Hixkaryana. Amsterdam: North-Holland.

Dickens, Patrick. 1994. English-Ju|'hoan, Ju|'hoan-English dictionary. Köln: Köppe.

Disbray, Samantha. 2005. Warumungu picture dictionary. Alice Springs, Australia: IAD Press.

Dixon, R. M. W. 1980. The languages of Australia. Cambridge: Cambridge University Press.

Dixon, R. M. W. 2004a. Proto-Arawá phonology. Anthropological Linguistics 46. 1-83.

Dixon, R. M. W. 2004b. The Jarawara language of southern Amazonia. Oxford: Oxford University Press.

Dixon, Ronald B. \& Alfred L. Kroeber. 1907. Numerical systems of the languages of California. American Anthropologist n.s. 9. 663-690.

Dooley, Robert A. 1982. Vocabulário do guarani: Vocabulário básico do guarani contemporâneo (dialeto mbüá do Brasil). Brasília: Summer Institute of Linguistics.

Early, John D. \& John F. Peters. 2000. The Xilixana Yanomami of the Amazon. Gainesville, FL: University Press of Florida.

Ekdahl, Muriel \& Nancy Butler. 1969. Terêna dictionary (Arquivo Lingüístico 95). Brasília: Summer Institute of Linguistics. 
Epps, Patience. 2006. Growing a numeral system: The historical development of numerals in an Amazonian language family. Diachronica 23. 259-288.

Epps, Patience. 2008. A grammar of Hup. Berlin: Mouton de Gruyter.

Epps, Patience \& Cynthia A. Hansen. 2011. 'One, two, three, brother': Etymological transparency in Amazonian numerals. Manuscript, University of Texas at Austin.

Ernst, Urs (ed.). 1989. Lexique kako-français, français-kako, avec tableaux de conjugaisons. Yaoundé, Cameroon: Société Internationale de Linguistique.

Etsio, Edouard. 1999. Parlons téké: Langue et culture. Paris: Harmattan.

Evans, Nicholas. 2009. Two pus one makes thirteen: Senary numerals in the Morehead-Maro region. Linguistic Typology 13. 321-335.

Evans, Nicholas \& Stephen Levinson. 2009. The myth of language universals: Language diversity and its importance for cognitive science. Behavioral and Brain Sciences 32. 429-492.

Everett, Caleb. 2006. Patterns in Karitiana: Articulation, perception, and grammar. Houston: Rice University doctoral dissertation.

Everett, Caleb (forthcoming). A closer look at a supposedly anumeric language. International Journal of American Linguistics.

Everett, Daniel. 1992. A língua pirahã e a teoria da sintaxe: Descrição, perspectivas e teoria. Campinas: Universidade Estadual de Campinas doctoral dissertation.

Everett, Daniel 2005. Cultural constraints on grammar and cognition in Pirahã: Another look at the design features of human language. Current Anthropology 46. 621-646.

Facundes, Sidney. 2001. Apurinã grammar. Buffalo: State University of New York doctoral dissertation.

Farris, Glen J. 1990. Vigesimal systems found in California Indian Languages. Journal of California and Great Basin Anthropology 12. 173-190.

Faust, Norma \& Eugene E. Loos. 2002. Gramática del idioma yaminahua. Lima: Instituto Lingüístico de Verano.

Ferreira, Rogério Vicente. 2005. Língua matis (pano): Uma descrição gramatical. Campinas, Brazil: Universidade Estadual de Campinas doctoral dissertation.

Fleck, David. 2003. A grammar of Matses. Houston: Rice University doctoral dissertation.

Foott, J. W. 1886. The Culgoa River. In Curr (ed.) 1886, Vol. 3, 328-329.

Foott, T. W. 1886. Nockatoonga, Wilson River. In Curr (ed.) 1886, Vol. 2, 34-35.

Frank, Michael, Daniel Everett, Evelina Fedorenko \& Edward Gibson. 2008. Number as a cognitive technology: Evidence from Pirahã language and cognition. Cognition 108. 819-824

Freeland, L. S. \& Sylvia M. Broadbent. 1960. Central Sierra Miwok dictionary. Berkeley, CA: University of California Press.

Furby, Christine E., Edward S. Furby, A. Rogers \& L. Rogers (no date). Garawa/Wanyi wordlist. Manuscript. Aboriginal Studies Electronic Data Archive (ASEDA) 0244. http://aseda.aiatsis. gov.au

Furby, Edward S. \& Christine E. Furby. 1977. A preliminary analysis of Garawa phrases and clauses (Pacific Linguistics B-42). Canberra: Australian National University.

Furby, Edward S. \& Christine E. Furby (no date). Garawa dictionary. Manuscript. Aboriginal Studies Electronic Data Archive (ASEDA) 0471. http://aseda.aiatsis.gov.au

Gabas Jr., Nilson. 1999. A grammar of Karo, Tupi (Brazil). Santa Barbara, CA: University of California Santa Barbara doctoral dissertation.

Geytenbeek, Brian \& Helen Geytenbeek. 1991. (Interim) Nyangumarta-English dictionary, with English-Nyangumarta finder-list. Manuscript. Aboriginal Studies Electronic Data Archive (ASEDA) 0217. http://aseda.aiatsis.gov.au

Gifford, Lord. 1886. Upper Sandford tribe. In Curr (ed.) 1886, Vol. 1, 375-379.

Givon, Talmy. 1980. Ute reference grammar. Ignacio, CO: Ute Press of the Southern Ute Tribe.

Glass, Amee. 1988. Ngaanyatjarra wordlist. Manuscript. Aboriginal Studies Electronic Data Archive (ASEDA) 0033. http://aseda.aiatsis.gov.au 
Glass, Amee \& Dorothy Hackett. 2003. Ngaanyatjarra-Ngaatjatjarra to English dictionary. Alice Springs, Australia: IAD Press.

Goddard, Cliff. 1987. A basic Pitjantjatjara/Yankunytjatjara to English dictionary. Alice Springs, Australia: Institute for Aboriginal Development.

Goddard, Cliff. 1992. Pitjantjatjara/Yankunytjatjara to English dictionary. 2nd edn. Alice Springs, Australia: Institute for Aboriginal Development.

Goddard, Cliff. 1996. Pitjantjatjara/Yankunytjatjara to English dictionary. Revised 2nd edn. Alice Springs, Australia: IAD Press.

Golla, Victor. 2011. California Indian languages. Berkeley, CA: University of California Press.

Gomez, Gale Goodwin. 1990. The Shiriana dialect of Yanam (Northern Brazil). New York: Columbia University doctoral dissertation.

Gordon, G. A. 1886. Deniliquin. In Curr (ed.) 1886, Vol. 3, 396-397.

Gordon, Peter. 2004. Numeral cognition without words: Evidence from Amazonia. Science 306. 496-499.

Green, Diana. 1994 [1996]. O sistema numérico da língua palikúr. Boletim do Museu Paraense Emílio Goeldi 10. 261-303.

Green, Diana. 1997. Diferenças entre termos numéricos em algumas línguas indígenas do brasil. Boletim do Museu Paraense Emílio Goeldi, Série Antropología 13. 179-207.

Green, Jenny. 2003. Central Anmatyerr picture dictionary. Alice Springs, Australia: IAD Press.

Green, Rebecca (no date). Mudburra vocabulary. Manuscript. Aboriginal Studies Electronic Data Archive (ASEDA) 0699. http://aseda.aiatsis.gov.au

Green, W. M. 1886a. Wonoka. In Curr (ed.) 1886, Vol. 2, 124-125.

Green, W. M. 1886b. Eastern shores of Lake Torrens. In Curr (ed.) 1886, Vol. 2, 126-129.

Greenberg, Joseph. 1978. Generalizations about numeral systems. In Joseph Greenberg, Charles A. Ferguson \& Edith A. Moravcsik (eds.), Universals of human language, Vol. 3: Word structure, 249-295. Stanford, CA: Stanford University Press.

Gross, Hans J. 2011. To bee or not to bee, this is the question. ... : The inborn numerical competence of humans and honeybees. Communicative Integrative Biology 4. 594-597.

Gruzdeva, Ekaterina. 1998. Nivkh. München: Lincom Europa.

Guirardello, Raquel. 1999. A reference grammar of Trumai. Houston: Rice University doctoral dissertation.

Gvozdanović, Jadranka (ed.). 1999. Numeral types and changes worldwide. Berlin: Mouton de Gruyter.

Haacke, Wilfrid H. G. \& Eliphas Eiseb. 2002. A Khoekhoegowab dictionary with an EnglishKhoekhoegowab index. Windhoek: Gamsberg Macmillan.

Hafford, James A. 1999. Elements of Wuvulu grammar. Arlington, TX: University of Texas at Arlington MA thesis.

Hale, Kenneth. 1967. Warlpiri wordlist. Manuscript. Aboriginal Studies Electronic Data Archive (ASEDA) 0082. http://aseda.aiatsis.gov.au

Hale, Kenneth. 1975. Gaps in culture and grammar. In M. Dale Kinkade, Kenneth L. Hale \& Oswald Werner (eds.), Linguistics and anthropology: In honor of C. F. Voegelin, 285-315. Lisse: de Ridder.

Hale, Kenneth. 1982. Jiwarliny. Manuscript. Aboriginal Studies Electronic Data Archive (ASEDA) 0015. http://aseda.aiatsis.gov.au

Hale, Kenneth. 1995. An elementary Warlpiri dictionary. Revised. Alice Springs, Australia: IAD Press.

Hammarström, Harald. 2008. Small numeral systems and the hunter-gatherer connection. Unpublished slides.

Hammarström, Harald. 2009. Whence the Kanam base-6 numeral system? Linguistic Typology 13. 305-319. 
Hammarström, Harald. 2010. Rarities in numeral systems. In Jan Wohlgemuth \& Michael Cysouw (eds.), Rethinking universals: How rarities affect linguistic theory, 11-59. Berlin: De Gruyter Mouton.

Hammond, H. 1886. The Balonne, Baleandoon, Nogara, and Nerran Rivers. In Curr (ed.) 1886, Vol. 3, 258-261.

Hanke, Thomas. 2005. Bildungsweisen von Numeralia: Eine typologische Untersuchung. Berlin: Weißensee-Verlag.

Hansen, Cynthia Andersen. 2007. Hands, fingers, feet, and toes? Oh brother: The numeral system in Iquito. Paper presented at the Symposium on Endangered Languages of Amazonia, University of Texas at Austin, February 17.

Harrington, John P. 1909. Notes on the Piro language. American Anthropologist 11. 563-594.

Harrington, John P. 1910. An introductory paper on the Tiwa language, dialect of Taos, New Mexico. American Anthropologist 12. 11-48.

Harris, John. 1987. Australian Aboriginal and Islander mathematics. Australian Aboriginal Studies 2. 29-37.

Haude, Katharina. 2006. A grammar of Movima. Nijmegen: Radboud Universiteit doctoral dissertation.

Headland, Janet \& Thomas Headland. 1974. A Dumagat (Casiguran)-English dictionary (Pacific Linguistics C-28). Canberra: Australian National University.

Heath, Jeffrey. 1980. Basic materials in Ritharngu: Grammar, texts, and dictionary (Pacific Linguistics B-62). Canberra: Australian National University.

Hedinger, Robert. 2008. A grammar of Akoose: A northwest Bantu language. Dallas: SIL International and the University of Texas at Arlington.

Heine, Bernd. 1981. The Waata dialect of Oromo: Grammatical sketch and vocabulary (Language and Dialect Atlas of Kenya 4). Berlin: Reimer.

Heine, Bernd. 1982. Boni dialects (Language and Dialect Atlas of Kenya 5). Berlin: Reimer.

Heine, Bernd. 1997. Cognitive foundations of grammar. Oxford: Oxford University Press.

Henrix, Marcel, Karel van den Eynde \& Michael Meeuwis. 2007. Description grammaticale de la langue ngbaka: Phonologie, tonologie, et morphosyntaxe. München: Lincom Europa.

Hercus, Luise. 1989. Arabana-Wangkanguru vocabulary. Manuscript.

Hercus, Luise. 1992. A Nukunu dictionary. Canberra: Hercus.

Hercus, Luise. 1994. A grammar of the Arabana-Wangkangurru language, Lake Eyre Basin, South Australia (Pacific Linguistics C-128). Canberra: Australian National University.

Hercus, Luise. 1999. A grammar of the Wirangu language from the west coast of South Australia (Pacific Linguistics C-150). Canberra: Australian National University.

Hercus, Luise (no date). Yarluyandi vocabulary. Manuscript. Aboriginal Studies Electronic Data Archive (ASEDA) 0251. http://aseda.aiatsis.gov.au

Hill, Jane H. 2005. A grammar of Cupeño. Berkeley, CA: University of California Press.

Hill, Jane H. \& Roscinda Nolasquez. 1973. Mulu'wetam: The first people. Morongo Indian Reservation, Banning, CA: Malki Museum Press.

Hill, Kenneth C. 2009. Tübatulabal dictionary. Manuscript.

Holmer, Nils M. 1988. Notes on some Queensland languages (Pacific Linguistics D-79). Canberra: Australian National University.

Honery, Thomas. 1877-1878. Wailwun language and traditions. Journal of the Royal Anthropological Institute 7. 246-254.

Hopi Dictionary Project. 1998. Hopi dictionary/Hopìkwa Lavàytutuveni. Tucson, AZ: University of Arizona Press.

Hosking, Dianne \& Sally McNicol. 1993. Wiradjuri. Canberra: Panther.

Howitt, Alfred. 1886. Cooper's Creek in the neighbourhood where Burke and Wills died. In Curr (ed.) 1886, Vol. 2, 30-31.

Huber, Randall \& Robert Reed. 1992. Comparative vocabulary: Selected words in indigenous languages of Colombia. Bogotá: Instituto Lingüístico de Verano. 
Hudson, Joyce \& Eirlys Richards. 1981. Walmatjari wordlist. In Menning \& Nash (eds.) 1981. Aboriginal Studies Electronic Data Archive (ASEDA) 0141. http://aseda.aiatsis.gov.au

Hudson, Joyce \& Eirlys Richards (no date). Walmajarri dictionary. Manuscript. Aboriginal Studies Electronic Data Archive (ASEDA) 0167. http://aseda.aiatsis.gov.au

Hurford, James R. 1975. The linguistic theory of numerals. Cambridge: Cambridge University Press.

Hurford, James R. 1987. Language and number. Oxford: Blackwell.

Hurford, James R. 2007. A performed practice explains a linguistic universal: Counting gives the Packing Strategy. Lingua 117. 773-783.

Hyde, Sylvia. 1980. Diccionario amahuaca (Serie Lingüística Peruana 7). Yarinacocha, Peru: Instituto Lingüístico de Verano. http://www.sil.org/americas/peru/show_work.asp?id=16019

Jacobs, F. E. 1886a. Kopperamana. In Curr (ed.) 1886, Vol. 2, 108-109.

Jacobs, F. E. 1886b. The north shore of Lake Eyre. In Curr (ed.) 1886, Vol. 2, 14-15.

Jacobs, F. E. 1886c. North-west of Lake Eyre. In Curr (ed.) 1886, Vol. 2, 12-13.

Jones, Caroline. 2005. Ngarinyman vocabulary. Manuscript. Aboriginal Studies Electronic Data Archive (ASEDA) 0796. http://aseda.aiatsis.gov.au

Junker, Laura. 2002. Introduction: Southeast Asia. In Kathleen Morrison \& Laura Junker (eds.), Forager-traders in South and Southeast Asia: Long-term histories, 131-166. Cambridge: Cambridge University Press.

Kagaya, Ryohei. 1993. A classified vocabulary of the Sandawe language (Asian \& African Lexicon 26). Tokyo: Institute for the Study of Languages and Cultures of Asia and Africa, Tokyo University of Foreign Studies.

Kaufman, E. L., M. W. Lord, T. W. Reese \& J. Volkmann. 1949. The discrimination of visual number. American Journal of Psychology 62. 498-525.

Kelly, Robert L. 1995. The foraging spectrum: Diversity in hunter-gatherer lifeways. Washington, DC: Smithsonian Institution Press.

Kendall, Martha B. 1977. The Upland Yuma numeral system. In James E. Redden (ed.) Proceedings of the 1976 Hokan-Yuman Languages Workshop, 17-28. Carbondale, IL: University Museum and Art Galleries, Southern Illinois University.

Kilian-Hatz, Christa. 2003. Khwe dictionary. Köln: Köppe.

Kingsmill, J. W. 1886. Vocabulary of the Kooyiannie language. In Curr (ed.) 1886, Vol. 2, 120-121.

Klar, Kathryn. 1980. Northern Chumash numerals. In Klar et al. (eds.) 1980, 112-119.

Klar, Kathryn, Margaret Langdon \& Shirley Silver (eds.). 1980. American Indian and Indoeuropean studies: Papers in honor of Madison S. Beeler. Den Haag: Mouton.

Klumpp, Deloris Pharris de. 1995. Vocabulario piapoco-español. Bogotá: SIL.

Koehn, Edward \& Sally Sharp Koehn. 1995. Vocabulário básico Apalaí-Português. Dicionário da língua Apalaí. Brasília: SIL.

Kofod, F. M. 1976. Miriwung - English. Manuscript. Australian Institute of Aboriginal and Torres Islander Studies MS 1896.

König, Christa \& Bernd Heine. 2008. A concise dictionary of Northwestern !Xun. Köln: Köppe.

Kroeber, Alfred L. 1910. The Chumash and Costanoan languages. University of California Publications in American Archaeology and Ethnology 9. 237-271.

Kroeber, Alfred L. 1925. Handbook of the Indians of California (Bureau of American Ethnology Bulletin 78). Washington, DC: Government Printing Office.

Kroeber, Alfred L. 1963. Yokuts dialect survey (Anthropological Records 11(3)). Berkeley, CA: University of California Press.

Kroeber, Alfred L. \& George W. Grace. 1960. The Sparkman grammar of Luiseño. Berkeley, CA: University of California Press.

Kruspe, Nicole. 2004. A grammar of Semelai. Cambridge: Cambridge University Press.

Kühn, Wilhelm. 1886. Yorke's Peninsula. In Curr (ed.) 1886, Vol. 2, 146-147.

Lachler, Jordan. 2006. A grammar of Laguna Keres. Albuquerque, NM: University of New Mexico doctoral dissertation. 
Lamb, Sydney. 1957. Mono grammar. Berkeley, CA: University of California doctoral dissertation. Landaburu, Jon. 1979. La langue des Andoke (Langues et Civilisations à Tradition Orale 36). Paris: Société d'études linguistiques et anthropologiques de France.

Langdon, Margaret \& Pamela Munro. 1980. Yuman numerals. In Klar et al. (eds.) 1980, 121-135.

Larmer, James. 1898. Native vocabulary of miscellaneous N.S.W. objects. Journal and Proceedings of the Royal Society of New South Wales 32. 223-229.

Laves, Gerhardt. 1929-1932. Papers of Gerhardt Laves. Manuscript. Australian Institute of Aboriginal and Torres Islander Studies MS 2189.

Leach, Ilo M. 1969. Vocabulario ocaina (Serie Lingüística Peruana 4). Yarinacocha, Peru: Instituto Lingüístico de Verano. http://www.sil.org/americas/peru/show_work.asp?id=11396

Lee, Richard B. \& Richard Daly (eds.). 1999. The Cambridge encyclopedia of hunters and gatherers. Cambridge: Cambridge University Press.

Lemos Barbosa, A. 1956. Curso de tupi antigo: Gramática, exercícios, textos. Rio de Janeiro: Livraria São José. http://biblio.etnolinguistica.org/barbosa-1956-curso

Le Souef, A. A. C. \& R. W. Holden. 1886. Port Lincoln. In Curr (ed.) 1886, Vol. 2, 8-9.

Levinsohn, Stephen H. 1976. The Inga language. Den Haag: Mouton.

Loeb, Edwin M. 1926. Pomo folkways. University of California Publications in American Archaeology and Ethnology 19(2). 229-230.

Loriot, James, Erwin Lauriault \& Dwight Day. 1993. Diccionario shipibo-castellano (Serie Lingüística Peruana 31). Yarinacocha, Peru: Instituto Lingüístico de Verano.

Love, J. R. B. 2000. The grammatical structure of the Worora language of north-western Australia. Edited by R. M. W. Dixon. München: Lincom Europa. Written in 1932.

Lowe, Beulah. 1996. Grammar lessons in Gupapuyngu. Darwin, Australia: Aboriginal Resource \& Development Services. Written in 1960.

Lukusa, Stephen T. M. \& Kemmonye C. Monaka. 2008. Shekgalagari grammar: A descriptive analysis of the language and its vocabulary. Cape Town: Centre for Advanced Studies of African Society.

Machattie, J. O. \& J. S. Little. 1886. Junction of King's Creek and the Georgina River. In Curr (ed.) 1886, Vol. 2, 366-370.

Mamiani, Luis Vincencio. 1877. Arte de grammatica da lingua brasilica da naçam Kiriri. Rio de Janeiro: Biblioteca Nacional. Originally published in 1699.

Marsh, Jim. 1992. Martu Wangka dictionary. Manuscript. Aboriginal Studies Electronic Data Archive (ASEDA) 0210. http://aseda.aiatsis.gov.au

Martins, Silvana. 2004. Fonologia e gramática dâw. Amsterdam: Vrije Universiteit doctoral dissertation.

Maslova, Elena. 2003. A grammar of Kolyma Yukaghir. Berlin: Mouton de Gruyter.

Mason, J. Alden. 1918. The language of the Salinan Indians. University of California Publications in American Archaeology and Ethnology 14. 1-154.

Mathews, R. H. 1902. Languages of some native tribes of Queensland, New South Wales and Victoria. Journal and Proceedings of the Royal Society of New South Wales 36. 135-190.

Mathews, Robert Hamilton. 1903. Languages of the Kamilaroi and other Aboriginal tribes of NSW. Journal of the Royal Anthropological Institute 33. 259-283.

Mattei-Müller, Marie-Claude \& Jacinto Serowèe. 2007. Lengua y cultura yanomami: Diccionario ilustrado yanomami-español, español-yanomami. Caracas: Gobierno Bolivariano de Venezuela, Consejo Nacional de la Cultura.

Matteson, Esther. 1965. The Piro (Arawakan) language. Berkeley, CA: University of California.

Matumo, Z. I. 1993. Setswana-English, English-Setswana dictionary. 4th edn. Gaborone, Botswana: Macmillan Botswana.

McCawley, William. 1996. The first Angelinos: The Gabrielino Indians of Los Angeles. Morongo Indian Reservation, Banning, CA: Malki Museum Press; Novato, CA: Ballena Press.

McConvell, Patrick. 1981. Malngin wordlist. In Menning \& Nash (eds.) 1981. Aboriginal Studies Electronic Data Archive (ASEDA) 0128. http://aseda.aiatsis.gov.au 
McConvell, Patrick \& David Nash. 1984. Mudburra wordlist. Manuscript. Aboriginal Studies Electronic Data Archive (ASEDA) 0031. http://aseda.aiatsis.gov.au

McDonald, Maryalyce \& Stephen A. Wurm. 1980. Basic materials in Wankumara (Galali): Grammars, sentences and vocabulary (Pacific Linguistics B-65). Canberra: Australian National University.

McEntee, John C. \& Pearl McKenzie. 1992. Adna-mat-na English dictionary. Manuscript. Australian Institute of Aboriginal and Torres Islander Studies MS 3146.

McFarlane, - . 1886. From the Mallee Cliffs to Wentworth. In Curr (ed.) 1886, Vol. 2, 282-284.

McGregor, William. 1988. Gooniyandi. Manuscript. Aboriginal Studies Electronic Data Archive (ASEDA) 0010. http://aseda.aiatsis.gov.au

McGregor, William. 1990. A functional grammar of Gooniyandi. Amsterdam: Benjamins.

McGregor, William. 1992. Handbook of Kimberley languages: Word lists. Vol. 2. Broome, Australia: Kimberley Language Resource Centre.

McGregor, William. 2004. The languages of the Kimberley, Western Australia. New York: RoutledgeCurzon

McGregor, William \& Alan Rumsey. 2009. Worrorran revisited: The case for genetic relations among languages of the Northern Kimberley region of Western Australia (Pacific Linguistics 600). Canberra: Australian National University.

McKelson, Kevin R. 1988. Mangala wordlist. Manuscript. Aboriginal Studies Electronic Data Archive (ASEDA) 0220. http://aseda. aiatsis.gov.au

McKelson, Kevin R. 1988-1989. Yulparija. Manuscript. Aboriginal Studies Electronic Data Archive (ASEDA) 0032. http://aseda.aiatsis.gov.au

McKelson, Kevin R. 1989. Karajarri wordlist. Manuscript. Aboriginal Studies Electronic Data Archive (ASEDA) 0069. http://aseda.aiatsis.gov.au

McLean, Alexander. 1886. Between the Georgina and Burke Rivers. In Curr (ed.) 1886, Vol. 2, 358-359.

McLeod, Ruth \& Valerie Mitchell. 1977. Aspectos da língua xavánte. Brasília: Summer Institute of Linguistics.

McNair, Norm \& Helen McNair (no date). Gurindji dictionary. Manuscript. Aboriginal Studies Electronic Data Archive (ASEDA) 0207. http://aseda.aiatsis.gov.au

McNair, Norm, Helen McNair \& Patrick McConvell. 1981. Gurindji wordlist. In Menning \& Nash (eds.) 1981. Aboriginal Studies Electronic Data Archive (ASEDA) 0118. http://aseda.aiatsis. gov.au

Melo, Elisângela. 2007. Investigações etnomatemáticas em contextos indígenas. Natal, Brazil: Universidade Federal do Rio Grande do Norte.

Meeussen, A. E. 1967. Bantu grammatical reconstruction. Annales du Musee Royal de l'Afrique Centrale 61. 81-121.

Meléndez, Miguel Angel. 1998. Lengua achagua. Bogotá: Colciencias, Universidad de las Andes.

Menning, Kathy \& David Nash (eds.). 1981. Sourcebook for central Australian languages. Alice Springs, Australia: Institute for Aboriginal Development.

Merlan, Francesca C. 1994. A grammar of Wardaman: Language of the Northern Territory of Australia. Berlin: Mouton de Gruyter.

Migliazza, Ernest C. 1972. Yanomama grammar and intelligibility. Bloomington, IN: Indiana University doctoral dissertation.

Mihas, Elena. 2010. Essentials of Ashéninka Perené grammar. Milwaukee, WI: University of Wisconsin doctoral dissertation.

Miller, Marion M. 1999. Desano grammar. Dallas: Summer Institute of Linguistics.

Miller, Wick R. 1965. Acoma grammar and texts. Berkeley, CA: University of California Press.

Minor, Dorothy A. \& Eugene Minor. 1971. Resumen de la gramática huitota. Lomalinda, Colombia: Townsend.

Minor, Eugene \& Dorothy A. Minor. 1987. Vocabulario bilingüe: Huitoto-español, españolhuitoto (dialecto minica). Lomalinda, Colombia: Townsend. 
Mixco, Mauricio J. 1985. Kiliwa dictionary (University of Utah Anthropological Papers 109). Salt Lake City: University of Utah Press.

Möhlig, Wilhelm J. G. \& Karl Peter Shiyaka-Mberema. 2005. A dictionary of the Rumanyo language: Rumanyo-English/English-Rumanyo: Including a grammatical sketch. Köln: Köppe.

Montag, Susan. 2008. Diccionario cashinahua (Serie Lingüística Peruana 9). 3rd edn. Yarinacocha: Instituto Lingüístico de Verano. http://www.sil.org/americas/peru/show_work.asp? id $=16193$

Moore, Denny. 1984. Syntax of the language of the Gavião Indians of Rondônia, Brazil. New York: City University of New York doctoral dissertation.

Morphy, Frances. 1983. Djapu, a Yolngu dialect. In R. M. W. Dixon \& Barry J. Blake (eds.), Handbook of Australian languages, Vol. 3, 1-188. Canberra: Australian National University Press.

Morse, Nancy L. \& Michael B. Maxwell. 1999. Cubeo grammar. Dallas: Summer Institute of Linguistics.

Moser, Mary B. \& Stephen A. Marlett. 1997. Los números en seri (SIL Electronic Working Papers 1997-005). Dallas: Summer Institute of Linguistics. http://www.sil.org/silewp/1997/005/ SILEWP1997-005.pdf

Moser, Mary B. \& Stephen A. Marlett. 2005. Comcáac quih yaza quih hant ihíip hac: Diccionario seri-español-inglés. Hermosillo: Unison; México: Plaza y Valdes.

Munro, Pamela, Nellie Brown \& Judith G. Crawford. 1993. A Mojave dictionary (UCLA Occasional Papers in Linguistics 10). Los Angeles, CA: Department of Linguistics, University of California, Los Angeles.

Myles, F. W. 1886. Thargominda, Bulloo River. In Curr (ed.) 1886, Vol. 2, 34-35.

Narungga Aboriginal Progress Association. 2006. Nharangga warra = Narungga dictionary. Maitland, Australia: Narungga Aboriginal Progress Association.

Nash, David \& Kenneth Hale. 1979. Preliminary vocabulary of Warlmanpa. Manuscript. Aboriginal Studies Electronic Data Archive (ASEDA) 0049. http://aseda.aiatsis.gov.au

Nash, David \& Kenneth Hale. 1981. Warlmanpa wordlist. In Menning \& Nash (eds.) 1981. Aboriginal Studies Electronic Data Archive (ASEDA) 0111. http://aseda.aiatsis.gov.au

Nekes, Hermann \& Ernest A. Worms. 2006. Australian languages. Edited by William B. McGregor. Berlin: Mouton de Gruyter. Originally published on microfilm (Micro-Bibliotheca Anthropos 10). Posieux, Switzerland: Anthropos-Institut, 1953.

Nevins, Andrew, David Pesetsky \& Cilene Rodrigues. 2009. Pirahã exceptionality: A reassessment. Language 85. 355-404.

Newman, Stanley S. 1944. Yokuts language of California (Viking Fund Publications in Anthropology 2). New York: Wenner-Gren Foundation for Anthropological Research.

Newman, Stanley S. 1958. Zuni dictionary (Indiana University Research Center Publications 6). Bloomington, IN: Indiana University.

Nicholson, Velda. 1982. Breve estudo da língua asuriní do Xingu (Ensaios Lingüísticos 5). Brasília: Summer Institute of Linguistics. http://www.sil.org/americas/brasil/publcns/ling/ AXBreve.pdf

Nordlinger, Rachel. 1998. A grammar of Wambaya, Northern Territory (Australia) (Pacific Linguistics C-140). Canberra: Australian National University.

Nordlinger, Rachel \& Caroline Jones (no date). Birlinarra. Manuscript. Aboriginal Studies Electronic Data Archive (ASEDA) 0661. http://aseda.aiatsis.gov.au

O'Grady, Geoffrey N. 1967a. Northern Mangarla wordlist. Manuscript. Aboriginal Studies Electronic Data Archive (ASEDA) 0192. http://aseda.aiatsis.gov.au

O'Grady, Geoffrey N. 1967b. Wirangu wordlist. Manuscript. Aboriginal Studies Electronic Data Archive (ASEDA) 0080. http://aseda.aiatsis.gov.au

O'Grady, Geoffrey N. 1967c. Yulparija wordlist. Manuscript. Aboriginal Studies Electronic Data Archive (ASEDA) 0087. http://aseda.aiatsis.gov.au 
O'Grady, Geoffrey N. (no date). Adnyamathanha wordlist. Manuscript. Aboriginal Studies Electronic Data Archive (ASEDA) 0064. http://aseda.aiatsis.gov.au

O’Grady, Geoffrey N. \& Terry J. Klokeid. 1969. Australian linguistic classification: A plea for coordination of effort. Oceania 39. 298-311.

Oates, Lynette (no date a). Muruwari dictionary. Manuscript. Aboriginal Studies Electronic Data Archive (ASEDA) 0252. http://aseda.aiatsis.gov.au

Oates, Lynette (no date b). Muruwari dictionary. Manuscript. Aboriginal Studies Electronic Data Archive (ASEDA) 0474. http://aseda.aiatsis.gov.au

Okrand, Mark. 1977. Mutsun grammar. Berkeley, CA: University of California doctoral dissertation.

Olawsky, Knut J. 2006. A grammar of Urarina. Berlin: Mouton de Gruyter.

Olson, James S. 1991. The Indians of Central and South America: An ethnohistorical dictionary. New York: Greenwood.

Ortiz, Alfonso (ed.). 1986. Handbook of North American Indians, Vol. 10: Southwest. Washington, DC: Smithsonian Institution.

Ospina Bozzi, Ana Maria. 2002. Les structures élémentaires du Yuhup Makú, langue de la Amazonie Colombienne: Morphologie et syntaxe. Paris: Université Paris 7 Denis Diderot doctoral dissertation.

Panter-Brick, Catherine, Robert Layton \& Peter Rowley-Conwy. 2001. Hunter-gatherers: An interdisciplinary perspective. Cambridge: Cambridge University Press.

Parker, Stephen G. (ed.) 1995. Datos de la lengua iñapari (Documentos de Trabajo 27). Yarinacocha, Peru: Instituto Lingüístico de Verano. http://www.sil.org/americas/peru/show_work. asp?id=36668

Pashi, Lumana \& Alan Turnbull. 1994. Lingala-English dictionary. Kensington, MD: Dunwoody.

Paull, W. J. 1886. Warburton River. In Curr (ed.) 1886, Vol. 2, 18-21.

Peeke, Catherine. 1991. Bosquejo gramatical del záparo (Cuadernos Etnolingüísticos 14). Quito: Summer Institute of Linguistics.

Peile, Anthony Rex. 1990. Kukatja dictionary. Manuscript. Aboriginal Studies Electronic Data Archive (ASEDA) 0023. http://aseda.aiatsis.gov.au

Peile, Anthony Rex. 1993 [1989]. A basic Kukatja to English dictionary. Edited by Hilaire Valiquette. Wirramanu (Balgo), Australia: Lurnpa Catholic School.

Pet, Willem J. A. 1987. Lokono Dian, the Arawak language of Surinam: A sketch of its grammatical structure and lexicon. Ithaca, NY: Cornell University doctoral dissertation.

Pica, Pierre, Cathy Lemer, Véronique Izard \& Stanislaus Dehaene. 2005. Exact and approximate arithmetic in an Amazonian indigene group. Science 306. 499-503.

Pilares Casas, Guido Alfredo. 2005. Los sistemas numericos del Quechua y el Aimara. Boletín Pedagógico Huascarán 57. http://portal.perueduca.edu.pe/boletin/boletin57/vinculos/ link\%20investigadores.pdf

Pitkin, Harvey. 1985. Wintu dictionary. Berkeley, CA: University of California Press.

Plank, Frans. 2009. Senary summary so far. Linguistic Typology 13. 337-345.

Politis, Gustavo. 2007. Nukak: Ethnoarchaeology of an Amazonian people, trans. Benjamin Alberto. Walnut Creek, CA: Left Coast Press.

Popjes, Jack \& Josephine Popjes. 1986. Canela-Krahô. In Desmond C. Derbyshire \& Geoffrey K. Pullum (eds.), Handbook of Amazonian languages, Vol. 1, 128-199. Berlin: Mouton de Gruyter.

Popovich, A. Harold \& Frances B. Popovich. 2005. Dicionário maxakalí-português. Cuiabá, Brazil: Sociedade Internacional de Lingüística.

Posey, Darrell. 1984. A preliminary report on diversified management of tropical rainforest by the Kayapó Indians of the Brazilian Amazon. Advances in Economic Botany 1. 112-126.

Pott, August Friedrich. 1847. Die quinare und vigesimale Zählmethode bei Völkern aller Welttheile. Halle: Schwetschke. 
Powlison, Paul. 1995. Nijyami miquejadamusiy may niquejadamujü: Mạ niquejadamusiy nijyami niquejadamuju (diccionario yagua-castellano) (Serie Lingüística Peruana 35). Lima: Ministerio de Educación and Instituto Lingüístico de Verano. http://www.sil.org/americas/peru/ show_work.asp?id=36352

Powlison, Paul \& Esther Powlison. 1958. El sistema numerico del Yagua (Pebano). Revista Peruana de Cultura 21. 3-8.

Praça, Walkíria Neiva. 2007. Morfossintaxe da língua Tapirapé. Brasília: Universidade de Brasília doctoral dissertation.

Press, Margaret L. 1979. Chemehuevi: A grammar and lexicon. Berkeley, CA: University of California Press.

Provis, C. 1886. Streaky Bay. In Curr (ed.) 1886, Vol. 2, 6-7.

Ramirez, Henri. 1997. A fala tukano dos Ye'pa-Masa, Vol. 1: Gramática. Manaus: Inspetoria Salesiana Missionária da Amazônia, CEDEM.

Ramirez, Henri. 2001. Línguas arawak da Amazônia setentrional: Comparação e descrição. Manaus: Editora da Universidade do Amazonas.

Raponda-Walker, André. 1996. Eléments de grammaire ghetsöghö. 2nd edn. Libreville, Gabon: Fondation Mgr Raponda-Walker.

Reed, H. J. \& Jean Lave. 1979. Arithmetic as a tool for investigating relations between culture and cognition. American Ethnologist 6. 568-582.

Reid, Lawrence. 1987. The early switch hypothesis: Linguistic evidence for contact between Negritos and Austronesians. Man and Culture in Oceania 3. 41-60.

Reuther, J. G. 1973. Three central Australian grammars: Diari, Jandruwanta, Wonkanguru (part of volume $V$ of the Reuther manuscript in the South Australian Museum). Edited by Luise A. Hercus \& J. G. Breen. Translated by T. Schwarzschild \& Luise A. Hercus. Canberra: Australian Institute of Aboriginal Studies.

Rich, Rolland G. 1999. Diccionario arabela-castellano (Serie Lingüístico Peruana 49). Lima: Instituto Lingüístico de Verano. http://www.sil.org/americas/peru/show_work.asp?id=39213

Richards, Eirlys \& Joyce Hudson. 1990. Walmajarri-English dictionary with English finder list. Darwin, Australia: Summer Institute of Linguistics.

Richardson, D. K. 1886. Streaky Bay. In Curr (ed.) 1886, Vol. 2, 3-5.

Ridley, William. 1875. Kamilaroi and other Australian languages. 2nd edn. Sydney: Government Printer.

Rival, Laura. 2006. Amazonian historical ecologies. Journal of the Royal Anthropological Institute 12 (special issue: Ethnobiology and the science of humankind). S79-S94.

Robertson, Carol. 1984. Wangkumara grammar and vocabulary. Sydney: Department of Technical and Further Education, Aboriginal Education Unit.

Rumsey, Alan. 2000. Bunuba. In R. M. W. Dixon \& Barry J. Blake (eds.), The handbook of Australian languages, Vol. 5, 34-153. Oxford: Oxford University Press.

Salmon, H. G. 1886. Cooper's Creek. In Curr (ed.) 1886, Vol. 2, 26-27.

Santos, Manuel Gomes dos. 2006. Uma gramática do wapixana (aruak): Aspectos da fonologia, da morfologia e da sintaxe. Campinas, Brazil: Universidade Estadual de Campinas doctoral dissertation.

Sapir, Edward. 1930. The Southern Paiute language (Proceedings of the American Academy of Arts and Sciences 65). New York: American Academy of Arts and Sciences.

Sawers, A. D. 1886. Gawler Range. In Curr (ed.) 1886, Vol. 2, 130-132.

Sawyer, Jesse O. 1965. English-Wappo vocabulary. Berkeley, CA: University of California Press.

Sawyer, Jesse O. \& Alice Schlichter. 1984. Yuki vocabulary. Berkeley, CA: University of California Press

Saxton, Dean, Lucille Saxton \& Susie Enos. 1983. Dictionary: Papago \& Pima to English, O'odham-Mil-gahn; English to Papago \& Pima, Mil-gahn-O'odham. Tucson, AZ: University of Arizona Press. 
Scandiuzzi, P. 2008. A numeração karib no Alto Xingu. Revista Latinoamericana de Etnomatemática $1.75-87$.

Schauer, Junia (ed.). 2005. Meke kemakánaka puráka7aloji: wapura7akó chu, eyá karíwana chu (Diccionario bilingüe: Yukuna-español; español-yukuna). Bogotá: Editorial Fundación para el Desarollo de los Pueblos Marginados.

Schebeck, Bernhard. 1973. Dhangu-English vocabulary (first draft). Manuscript, Yirrkala, Australia.

Schmidl, Marianne. 1915. Zahl und Zählen in Afrika. Mitteilungen der Anthropologischen Gesellschaft in Wien 35. 165-209.

Schmidt, Wilhelm. 1919. Die Gliederung der australischen Sprachen: Geographische, bibliographische, linguistische Grundzüge der Erforschung der australischen Sprachen. Wien: Mechitharisten-Buchdruckerei.

Schürmann, C. W. 1844. A vocabulary of the Parnkalla language spoken by the natives inhabiting the western shores of Spencers Gulf, to which is prefixed a collection of grammatical rules hitherto ascertained. Adelaide: Dehane. Aboriginal Studies Electronic Data Archive (ASEDA) 0256). http://aseda.aiatsis.gov.au

Schürmann, C. W. 1967. Pankarla. Manuscript. Aboriginal Studies Electronic Data Archive (ASEDA) 0077. http://aseda.aiatsis.gov.au

Seifart, Frank. 2005. The structure and use of shape-based noun classes in Miraña (North West Amazon). Nijmegen: Radboud Universiteit doctoral dissertation.

Seiler, Hansjakob. 1977. Cahuilla grammar. Morongo Indian Reservation, Banning, CA: Malki Museum Press.

Seiler, Hansjakob \& Kojiro Hioki. 1979. Cahuilla dictionary. Morongo Indian Reservation, Banning, CA: Malki Museum Press.

Seki, Lucy. 2000. Gramática do kamaiurá, língua tupi-guarani do Alto Xingu. Campinas, Brazil: Editora da Unicamp; São Paulo: Imprensa Oficial.

Shaul, David. 1995. The Huelel (Esselen) language. International Journal of American Linguistics 61. 191-239.

Shipley, William F. 1963. Maidu texts and dictionary. Berkeley, CA: University of California Press. Simpson, Jane. 2002. A learner's guide to Warumungu = Mirlamirlajinjjiki Warumunguku Apparrka. Alice Springs, Australia: IAD Press.

Simpson, Jane \& Jeffrey Heath. 1982. Warumungu sketch grammar: Draft 4. Manuscript, Massachusetts Institute of Technology and Harvard University. Australian Institute of Aboriginal and Torres Islander Studies MS 1860.

Snapp, Allen, John Anderson \& Joy Anderson. 1982. Northern Paiute. In Ronald W. Langacker (ed.), Studies in Uto-Aztecan grammar, Vol. 3: Uto-Aztecan grammatical sketches, 1-92. Dallas, TX: Summer Institute of Linguistics.

Snell, Betty (ed.) 1998. Pequeño diccionario machiguenga-castellano (Documentos de Trabajo 32). Pucallpa: Instituto Lingüístico de Verano. http://www.sil.org/americas/peru/show_work. asp?id=38991

Sommer, Bruce A. 1967. Kuuk Thaayorre wordlist. Manuscript. Aboriginal Studies Electronic Data Archive (ASEDA) 0101. http://aseda.aiatsis.gov.au

Spaepen, Elizabet, Marie Coppola, Elizabeth S. Spelke, Susan E. Carey \& Susan Goldin-Meadow. 2011. Number without a language model. PNAS 108. 3163-3168. http://www.pnas.org/cgi/ doi/10.1073/pnas.1015975108

Spielmann, Katherine \& James Eder. 1994. Hunters and farmers: Then and now. Annual Review of Anthropology 23. 303-323.

Stampe, David. 1976. Cardinal number systems. Chicago Linguistic Society 12. 594-609.

Stanley, Carol. 1986. Description morpho-syntaxique de la langue tikar, parlée au Cameroun. Paris: Université Sorbonne Nouvelle doctoral dissertation.

Stenzel, Kristine S. 2004. A reference grammar of Wanano. Boulder, CO: University of Colorado doctoral dissertation. 
Strelley School \& Pilbara Aboriginal Language Centre (no date). Nyangumarta wordlist. Manuscript. Aboriginal Studies Electronic Data Archive (ASEDA) 0278. http://aseda.aiatsis.gov. au

Strom, Clay 1992. Retuarã syntax. Dallas: Summer Institute of Linguistics.

Stubbs, Brian. 2011. Uto-Aztecan: A comparative vocabulary. Flower Mound, TX: Shumway Family History Services; Blanding, UT: Rocky Mountain Books and Productions.

Sullivan, A. F. \& Ernest Eglinton. 1886. Cooper's Creek, near the Booloo River. In Curr (ed.) 1886, Vol. 2, 32-33.

Swadesh, Morris. 1971. The origin and diversification of language. Chicago: Aldine-Atherton.

Swartz, Steve. 1996. Warlpiri-English dictionary. Manuscript, Alice Springs, Australia: St. Mary’s Children's Village.

Tanaka, Jiro \& Kazuyoshi Sugawara (eds.). 2010. An encyclopedia of /Gui and /Gana culture and society. Kyoto: Laboratory of Cultural Anthropology, Graduate School of Human and Environmental Studies, Kyoto University.

Teichelmann, C. G. \& C. W. Schürmann. 1840. Outlines of a grammar, vocabulary, and phraseology, of the Aboriginal language of South Australia, spoken by the natives in and for some distance around Adelaide. Adelaide: Teichelmann \& Schürmann.

Teichelmann, C. G. \& C. W. Schürmann. 1967. Kaurna wordlist. Manuscript. Aboriginal Studies Electronic Data Archive (ASEDA) 0068. http://aseda.aiatsis.gov.au

Teichelmann, C. G., C. W. Schürmann \& Jane Simpson. 1990. Kaurna vocabulary. Manuscript. Aboriginal Studies Electronic Data Archive (ASEDA) 0201. http://aseda.aiatsis.gov.au

Teichelmann, C. G., C. W. Schürmann \& W. Wyatt. 1886. Adelaide and its neighbourhood. In Curr (ed.) 1886, Vol. 2, 148-149.

Thieberger, Nicholas \& Desmond Taylor. 1987. Warnman wordlist. Manuscript. Aboriginal Studies Electronic Data Archive (ASEDA) 0053. http://aseda.aiatsis.gov.au

Thiesen, Wesley \& Eva Thiesen. 1998. Diccionario bora-castellano, castellano-bora (Serie Lingüística Peruana 46). Yarinacocha, Peru: Instituto Lingüístico de Verano. http://www.sil. org/americas/peru/show_work.asp?id=38825

Thomas, Bruce, Frank Thomas \& Brian Geytenbeek. 1990. Aboriginal languages of the Pilbara: Nyangumarta. Manuscript. Aboriginal Studies Electronic Data Archive (ASEDA) 0321. http://aseda.aiatsis.gov.au

Thomas, Jacqueline M. C., Serge Bahuchet, Alain Epelboin \& Susanne Furniss (eds.). 1981present. Encyclopédie des Pygmées Aka: Techniques, langage et société des chasseurscueilleurs de la forêt centrafricaine (Sud-Centrafrique et Nord-Congo). (Langues et Civilisations à Tradition Orale 50). Paris: Société d'études linguistiques et anthropologiques de France.

Thornes, Timothy. 2003. A Northern Paiute grammar with texts. Eugene, OR: University of Oregon doctoral dissertation.

Tindale, Norman B. 1940. Distribution of Australian Aboriginal tribes: A field survey. Transactions of the Royal Society of South Australia 64(1). 140-231.

Todd, Charles. 1886. Peake Telegraph Station. In Curr (ed.) 1886, Vol. 2, 10-11.

Tosco, Mauro. 1991. A grammatical sketch of Dahalo, including texts and a glossary. Hamburg: Buske.

Trager, George L. 1946. An outline of Taos grammar. In Harry Hoijer (ed.), Linguistic structures in North America (Viking Fund Publications in Anthropology 6), 184-221. New York: WennerGren Foundation for Anthropological Research.

Traill, Anthony. 1994. A !Xóõ dictionary. Köln: Köppe.

Turner, Kathleen. 1987. Aspects of Salinan grammar. Berkeley, CA: University of California Berkeley doctoral dissertation.

Tsunoda, Tasaku \& Joyce Hudson. 1981. Jaru wordlist. In Menning \& Nash (eds.) 1981. Aboriginal Studies Electronic Data Archive (ASEDA) 0119. http://aseda.aiatsis.gov.au 
Uldall, Hans-Joergen \& William F. Shipley. 1966. Nisenan texts and dictionary. Berkeley, CA: University of California Press.

Vajda, Edward. 2004. Ket. München: Lincom Europa.

Valadares, Simoni M. B. 1994. Aspectos da língua Kurripako (Kumandene). Universidade Federal de Santa Catarina MA thesis.

Valentine, J. C. 1886. Mount Remarkable. In Curr (ed.) 1886, Vol. 2, 136-139.

van der Voort, Hein. 2006. A grammar of Kwaza. Berlin: Mouton de Gruyter.

Velie, Daniel \& Virginia Velie. 1981. Vocabulario orejón (Serie Lingüística Peruana 16). Yarinacocha: Instituto Lingüístico de Verano. http://www.sil.org/americas/peru/show_work.asp? $\mathrm{id}=16766$

Viljoen, J. J. \& T. K. Kamupingene. 1983. Otjiherero woordeboek = Otjiherero dictionary: Embo romambo. Windhoek: Gamsberg.

Visser, Hessel. 2001. Naro dictionary: Naro-English, English-Naro. 4th edn. Gantsi, Botswana: Naro Language Project.

Voegelin, Charles F. 1935. Tübatulabal grammar. University of California Publications in American Archaeology and Ethnology 34(2). 55-190.

Vorbichler, Anton. 1965. Die Phonologie und Morphologie des Balese (Ituri-Urwald, Kongo) (Afrikanistische Forschungen 2). Glückstadt: Augustin.

Vuillermet, Marine (in preparation). Grammaire de l'ese ejja (tacana) de Bolivie, langue amazonienne. Lyon: Université Lumière Lyon 2 doctoral dissertation.

Wangka Maya, Pilbara Aboriginal Language Centre, Pijuka Eidwun, Minyawu Miller, Desmond Taylor, Muuki Taylor, Waka Taylor, Nicholas Thieberger, James Marsh \& Margaret Florey. 1991. Warnman wordlist. Manuscript. Aboriginal Studies Electronic Data Archive (ASEDA) 0334. http://aseda.aiatsis.gov.au

Warren, John. 1886. Strangway Springs. In Curr (ed.) 1886, Vol. 2, 110-111.

Warren, John \& John Hogarth. 1886. West of Lake Eyre. In Curr (ed.) 1886, Vol. 2, 16-17.

Waters, Bruce. 1988. Djinang dictionary. Manuscript. Aboriginal Studies Electronic Data Archive (ASEDA) 0009. http://aseda.aiatsis.gov.au

Weir, E. M. Helen. 1984. A negação e outros tópicos da gramática nadëb. Campinas, Brazil: Universidade Estadual de Campinas MA thesis.

Wheeler, Alva. 1970. Grammar of the Siona language, Colombia. Berkeley, CA: University of California doctoral dissertation.

Williams, Corinne J. 1980. A grammar of Yuwaalaraay (Pacific Linguistics B-74). Canberra: Australian National University.

Winter, Werner. 1999. When numeral systems are expanded. In Gvozdanović (ed.) 1999, 43-54.

Zaslavsky, Claudia. 1973. Africa counts: Number and pattern in African culture. Boston: Prindle, Weber \& Schmidt.

Zent, Eglée \& Stanford Zent. 2004. Amazonian Indians as ecological disturbance agents: The Hoti of the Sierra de Maigualida, Venezuelan Guyana. In Thomas J. S. Carlson \& Luisa Maffi (eds.), Ethnobotany and conservation of biological diversity, 79-112. New York: New York Botanical Garden Press.

Zentz, Jason \& Claire Bowern. 2011. Diversity in the numeral systems of Australian huntergatherers. Paper presented at the 85th annual meeting of the Linguistic Society of America, Pittsburgh, January 6-9.

Zepeda, Ofelia. 1983. A Papago grammar. Tucson: University of Arizona Press.

Zerbian, Sabine \& Manfred Krifka. 2008. Quantification across Bantu languages. In Lisa Matthewson (ed.), Quantification: A cross-linguistic perspective, 383-414. Bingley: Emerald.

Zigmond, Maurice L., Curtis G. Booth \& Pamela Munro. 1991. Kawaiisu: A grammar and dictionary with texts. Berkeley, CA: University of California Press.

Zorc, R. David. 1986. Yolngu-Matha dictionary. Batchelor, Australia: School of Australian Linguistics, Darwin Institute of Technology. 